\title{
Marcel Gautherot na revista Módulo - ensaios fotográficos, imagens do Brasil: da cultura material e imaterial à arquitetura'
}

\section{Heliana Angotti-Salgueiro ${ }^{2}$}

RESUMO: Este artigo tece considerações sobre as fotografias de Marcel Gautherot na Módulo, Revista de Arquitetura e Artes Plásticas fundada em 1955 por Oscar Niemeyer, quando ele iá era conhecido nos anais da arquitetura internacional. $\bigcirc$ texto visa levantar questões de método diante das lacunas da historiografia dos periódicos no país e, sobretudo, destacar a importância da Módulo e de suas reportagens fotográficas, lembrando o seu papel na afirmação e difusão da arquitetura moderna brasileira, além de refletir sobre o anonimato de fotógrafos nas publicações do gênero. A revista evidencia que para os homens daquela geração, a nova arquitetura era indissociável da afirmação da identidade nacional, ao lado das artes plásticas, do patrimônio histórico, e das representações da cultura material e imaterial - arquitetura vernacular, folclore, jogo da capoeira, arte popular (carrancas de proa), e outros temas que são, justamente, os das séries fotográficas do acervo de Marcel Gautherot, figurando nos números da primeira fase da revista até os anos 1960. A análise destaca, especialmente, o registro fotográfico da construção de Brasília, foco principal da retórica programática do periódico.

PALAVRAS-CHAVE: Marcel Gautherot. Periódico de arquitetura. Fotografia Moderna. Módulo. Oscar Niemeyer. Brasília.

ABSTRACT: This article is about photographs of Marcel Gautherot published in Módulo magazine, a Review of Architecture and Visual Arts, created by Oscar Niemeyer in 1955, when he was already internationally known as an architect. The purpose of the text is to raise methodological questions around the hiatus on historiography concerning periodicals in this country, and specially to show the role of Módulo and its photographic reports on affirmation and diffusion of modern Brazilian architecture, also considering the anonymity of photographs on architectural publications. The periodical demonstrates that for the men of that generation, the new architecture was connected to a nationalist view on identity, manifested by the visual arts, the historical heritage and the representations of material and immaterial culture - vernacular architecture, folklore, capoeira, popular art (like figureheads on boats), and other subjects that
1. Este artigo baseou-se em uma comunicação com o mesmo título, apresentada em 14/12/2004, na Jornada de Estudos Representações do Brasil: séries, coleções $e$ apropriações editoriais da fotografia nos anos 1940/1960, realizada na Universidade Federal Fluminense, no âmbito do projeto Travel Images as Icons of Brazil (19301960s). Art and Visual Conventions in Marcel Gautherot's Photographic Series, que desenvolvi com Lygia Segala entre 20042007, graças a uma bolsa (Collaborative Grant) outorgada pela The Getty Foundation. Além das jornadas de estudos que organizamos em São Paulo, Niterói e Paris, nossa pesquisa resultou em exposição internacional e catálogo editado pela Fundação Armando Alvares Penteado, que acolheu o projeto. Ver: Heliana Angotti-Salgueiro (2007b). Em 2009/2010 ampliei as temáticas dessa comunicação em projeto de pesquisa enviado à $\mathrm{J}$. $\mathrm{S}$. Guggenheim Foundation, Lighted Forms of Brazilian Modern Architecture: the case of Marcel Gautherot photographying Brasília, e 
em projeto de exposição sobre Brasília, que não se efetivou. A versão da comunicação aqui publicada conta com acréscimo de considerações, notas e bibliografia.

2. Doutora em História da Arte pela École des Hautes Études en Sciences Sociales de Paris (EHESS, 1992), com pós-doutorados, pesquisas e curadorias fomentados pela The Getty Foundation, Conselho Nacional de Pesquisas e Tecnologia (CNPq), Fundação de Amparo à Pesquisa do Estado de São Paulo (FAPESP), Association of Research Institutes in the Art History (ARIAH) e Fundação Armando Alvares Penteado (FAAP). Foi Professora Titular da Cátedra Brasileira em Ciências Sociais Sérgio Buarque de Hollanda (EHESS-Maison des Sciences de l'Homme, em Paris, entre 2004-2008) e professora-visitante nas universidades de La Rochelle, Poitiers e Tours. É autora de livros e artigos nas áreas de história da arquitetura e do urbanismo, história da arte, epistemologia e história da geografia e história da fotografia. Atualmente é bolsista da CAPES, junto ao Programa de Pós-Graduação da Faculdade de Arquitetura e Urbanismo da Universidade Presbiteriana Mackenzie. E-mail: <angotti@usp.br>.

3. O primeiro número da Módulo saiu em março de 1955; este artigo enfoca especialmente as reportagens com fotografias de Marcel Gautherot em números até 1962 are the same on Gautherot's collection, appearing since the first issues of the magazine until the 60 's. The analysis specially highlights photographs of the construction of Brasilia, main topic of the programmatic rhetoric of the periodical.

KEY-WORDS: Marcel Gautherot. Architecture Magazine. Modern Photography. Módulo. Oscar Niemeyer. Brasilia.

\section{INTRODUÇÃO}

objetivo deste artigo é levantar questões em dois níveis: o primeiro vem de uma preocupação metodológica a respeito das lacunas sobre periódicos relativos à arquitetura no país e ao papel da fotografia nos mesmos quanto à afirmação e difusão do modernismo; o segundo é destacar a importância da revista Módulo, da qual não se conheciam análises específicas, situando-a nos ideários do arquiteto Oscar Niemeyer (seu diretor) e nos de sua geração. Procurando associar esses dois níveis, interessam-me, especialmente, as reportagens fotográficas de Marcel Gautherot, fotógrafo francês ativo no Brasil desde os anos 1940. Essas reportagens, a partir do primeiro número da Módulo em 1955, inscrevem-se nos seguintes campos: cultura material, imaterial e arquitetura moderna brasileira, destacando-se, paulatinamente as fotografias sobre a construção de Brasília, que aparecem, na maioria das vezes, como era de praxe em periódicos de arquitetura, sem identificação de autoria.

Inicialmente, apresento o título, que remete às teorias de Le Corbusier, considero os princípios editorais fundadores da revista, e comento as carências da historiografia sobre periódicos, bem como o anonimato dos fotógrafos, até mesmo em clichês de ampla e repetida circulação internacional. As temáticas da revista Módulo na sua primeira fase ${ }^{3}$ evidenciam que para os homens daquela geração, a arquitetura moderna era indissociável da afirmação da identidade e cultura nacionais, ao lado não apenas das artes plásticas, mas do patrimônio histórico, da arquitetura vernacular, de aspectos da natureza do país, seu folclore, arte popular, e outros temas afins que são, justamente, temas recorrentes nas séries fotográficas do acervo de Gautherot, hoje conservadas no Instituto Moreira Salles. Na Módulo, observamos que estes temas vão cedendo o lugar às reportagens sobre a construção e arquitetura de Brasília, que se tornarão matéria dominante.

Marcel Gautherot, fotógrafo francês que chegara ao Brasil em 1941 , logo se liga a instituições e a pessoas de destaque na afirmação da ideia de uma cultura brasileira, como o SPHAN e Oscar Niemeyer, e aos circuitos e contextos a ela associados. Mas, se sua obra hoje é considerada representativa de muitos deles, não se pode, porém, compreendê-la sem o conhecimento de linguagens da fotografia europeia do entre-guerras, - o Construtivismo e a Nova Objetividade entre elas -, presentes em algumas de suas séries comentadas em retrospectiva de suas experiências vividas anteriormente na Paris dos anos 1930, cujo domínio é imprescindível ao pesquisador. 
A análise das fotografias da Módulo e a busca de autoria, das capas às reportagens, é feita com base no cotejamento das mesmas com as séries do acervo de Marcel Gautherot conservado no Instituto Moreira Salles, no Rio de Janeiro. $\bigcirc$ conhecimento deste acervo, em pesquisas anteriores, possibilitou-me levantar a atribuição de clichês da revista, bem como a considerar algumas intervenções da diagramação. Este trabalho prolonga, pois, pesquisas que desenvolvemos sobre Marcel Gautherot desde 20044, buscando aprofundar seu papel na produção e registro das representações do Brasil e na memória documental do nascimento de Brasília. Estas fotografias e as que retratam a cultura material e imaterial brasileiras foram também tema de exposições fora do país noticiadas na Módulo e comentadas no final do artigo, das quais muitas delas podem ser atribuídas a Gautherot, que tornou-se um dos fotógrafos mais conhecidos na atualidade pela cristalização da imagem da nova capital.

Do periódico: título, princípios e autoria fotográfica

Queremos que esta revista, que forçosamente será de interesse técnico, e se dirige especialmente a profissionais e artistas, tenha sempre a humildade e a força de ser alguma coisa a respeito do homem comum, esse exilado de nosso tempo e de nossa cidade.

A Redação, Módulo n 1, 1955.
4. Ver em Referências as publicações de Angotti-Salgueiro e Segala a partir de 2005.

5. A revista circulou até 1965 quando sua sede foi invadida e saqueada pelo regime militar. Voltou a circular de 1975 a 1989 , mas a fase que me interessa comentar neste texto é a dos primeiros anos, até 1962, enquanto Gautherot fazia parte do grupo de fotógrafos da redação.

6. A expressão é de Hélène Jannière (2002, p. 143). Este livro é uma obra de referência incontornável para os pesquisadores interessados em periódicos de arquitetura.

7. Ver A revista... (1955).
Módulo apresenta-se como uma revista de arquitetura e artes plásticas que começa a circular em março de $1955^{5}$ sob a direção do arquiteto Oscar Niemeyer, do engenheiro Joaquim Cardozo, seu braço direito, além de Rodrigo Melo Franco de Andrade (então diretor do DPHAN), o escritor Rubem Braga e o arquiteto Zenon Lotufo; em seguida, outros nomes são acrescentados à equipe de direção. Desde o primeiro número, já contava com correspondentes nacionais, devidamente identificados no sumário: Carlos Lemos em São Paulo, Edgar Graeff em Porto Alegre, Rafael Hardy em Belo Horizonte, Lucio Estelita em Recife e José Bina Fonyat em Salvador. Módulo dispunha também, como era de praxe em revistas congêneres, de correspondentes que asseguravam sua circulação para além das nossas fronteiras. A ambição de ser internacional, "condição necessária de uma revista moderna" ${ }^{\prime}$, confirmava-se na qualidade gráfica e nas traduções resumidas dos artigos em inglês, francês e alemão nos primeiros números, para em seguida serem traduzidos na íntegra e reunidos em separata. A designação "revista" explicita, por sua vez, ambições teóricas, pois não se tratava de gazeta, jornal, ou boletim.

Na Módulo n ${ }^{\circ}$ 1, a redação assinou o editorial "A revista e o título"7, em que há referência explícita ao sistema de medidas para determinar as proporções das unidades do edifício baseado nas proporções do corpo humano - "recriadas e racionalizadas pelo gênio de Le Corbusier, no seu Modulor" - observando-se que são antes "a altura e as proporções deste bicho da terra tão pequeno e não uma fração decimal do meridiano terrestre, que the serve de padrão". As intenções de 
8. Cf. o verbete Modulor, em Le Corbusier, une encyclopedie (1987, p. 259-261). Peter Collins escreve um editorial sobre o Modulor em The Architectural Review, vol. 116, n. 691, jul. 1954.

9. A fotografia é de Robert Doisneau (Agence Rapho) feita na cobertura-jardim do apartamento-ateliê de Le Corbusier, na rua Nungesser-et-Coli n. 24, em Paris em 1943. Agradeço esta informação a Isabelle Godineau, da Fondation Le Corbusier.

10. Assim, completa Niemeyer: "toda a cidade seria mais humana e feliz. Suas belezas naturais protegidas e seus monumentos realçados por um plano de urbanismo correto, contra o qual se anulariam interesses subalternos". (1955a, p. 3). Em seus textos de juventude, Le Corbusier havia escrito entre 1910 e 1915 , sobre a transformação da cidade para "a felicidade dos homens", ver Le Corbusier (1992). respeito à escala humana acolhida pela revista em seu próprio título, levando em conta o conforto na relação entre o homem e o seu espaço vital, foram acompanhadas da retórica social modernista, na declaração dos princípios: embora a revista fosse "forçosamente de interesse técnico", e dirigida "especialmente a profissionais e artistas", ela teria "a humildade e a força de ser alguma coisa a serviço do homem comum, esse exilado do nosso tempo e da cidade (...) humilhado entre paredes e máquinas". A carta de intenções termina reiterando a fidelidade à "singela medida do humano" entre os "prodígios da técnica e as fantasias da estética".

Sabe-se que Le Modulor fora apresentado primeiramente em 1943 por Le Corbusier, e que, em 1948, o arquiteto retomou sua explicação e publicou, em 1950, Le Modulor. Essai sur une mesure harmonique à l'échelle humaine applicable universellement à l'architecture et à la mécanique. O livro Modulor II aparece em 1955, com o sugestivo subtítulo la parole est aux usagers, comprovando a repercussão e os debates em torno do sistema de medidas criado pelo mestre suíçofrancês. O Modulor (conjunção de module+nombre d'or) é ligado ao interesse pelas proporções de uma nova arquitetura, em pleno período de reconstrução das cidades destruídas pela guerra, afigurando-se como um instrumento pedagógico para normalizar a produção industrial moderna, além de ser um instrumento de atividade criadora. Nesse sentido, se inscrito na própria obra de Le Corbusier, a partir da Unidade de Habitação de Marselha (Figura 1), o Modulor afigura-se mais como uma pesquisa de ordem poética e uma reflexão artística, do que como um método matemático de harmonias geométricas entre o homem e a casa ${ }^{8}$.

Uma fotografia de Le Corbusier seguindo os postulados de retratos da Nova Visão na tomada oblíqua de baixo para cima divide a página dupla que abre a Módulo $n^{\circ}$, com editorial explicativo do título de um lado, e texto de intenções e princípios de outro (Figura 2), baseado em nota elaborada por Oscar Niemeyer para ser lido em programa da Rádio MEC (não se indica a data), fato que não acontecera, pois este não aceitou os cortes da censura. $\bigcirc$ tom de manifesto característico do arquiteto engajado está aí explícito e a referência é Le Corbusier, seu "urbanismo humano" e sua arquitetura "vazada de solidariedade" - "um libelo contra esse regime de mistificações e injustiças em que vivemos, onde o interesse das coletividades está invariavelmente sujeito às imposições de classe, e [em que] les joies essentielles [a expressão alegrias essenciais está em La Maison des hommes, de Le Corbusier e Pierrefeu, escrita em 1942,] são privilégio de pequena minoria". O texto destaca ainda o papel do "mestre" na afirmação da nossa arquitetura e louva, sobretudo, o modelo da ville verte solidária:

...grandes blocos de habitação coletiva, suspensos em colunas, cercados de parques, jardins, creches, clubes, cinemas, mercados, etc. E nesses maravilhosos conjuntos os homens não ficariam (...) confinados em estreitos apartamentos. Suas janelas não abririam sobre os prédios vizinhos, nem para as ruas estreitas, nem para o barulho infernal que nos impede a recuperação das energias que o trabalho diário solicita. (...) Grandes espaços livres separariam as habitações, garantindo-thes o contato direto com a natureza, que é uma das exigências da vida moderna, e as vias de circulação seriam rigorosamente distribuídas entre pedestres e veículos ${ }^{10}$. 


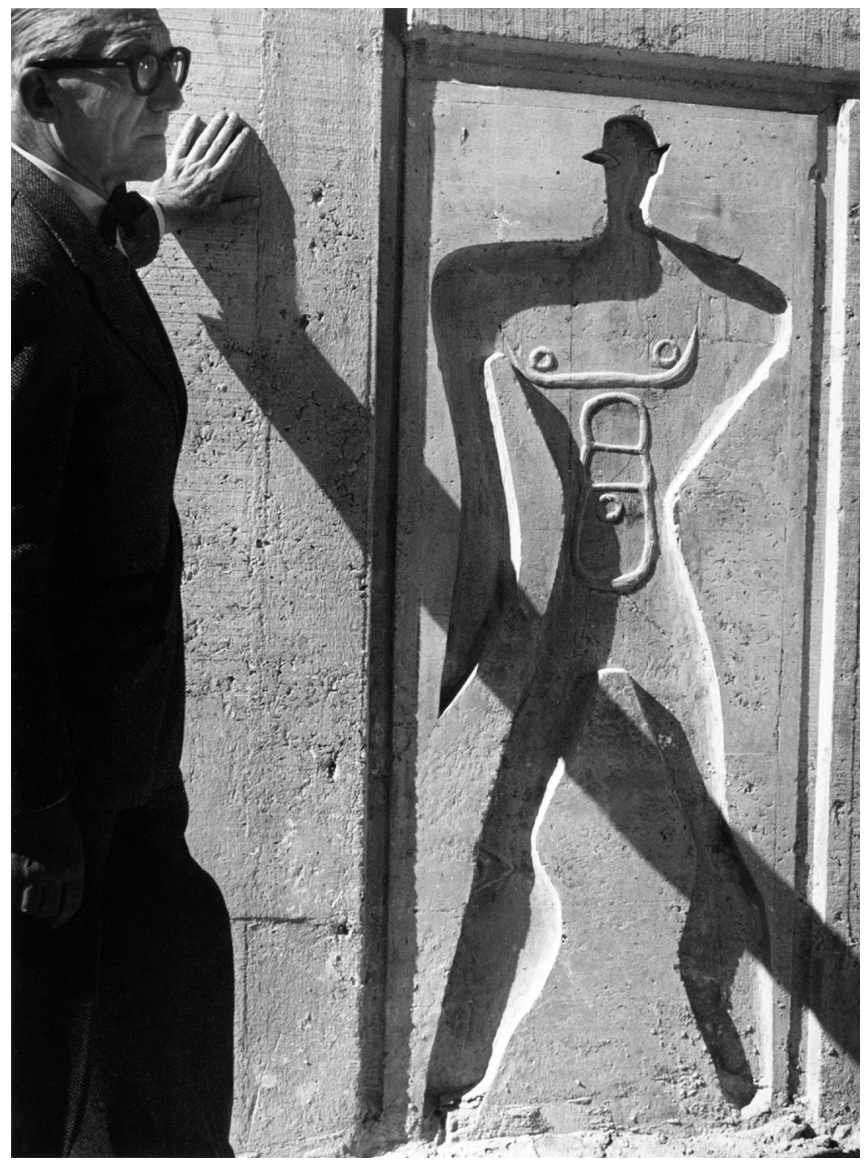

Figura 1 - Le Corbusier fotografado por Lucien Hervé diante do desenho do baixo-relevo do Modulor, na Unidade de Habitação, em Marselha, 1952. (C) Fondation Le Corbusier, Paris.

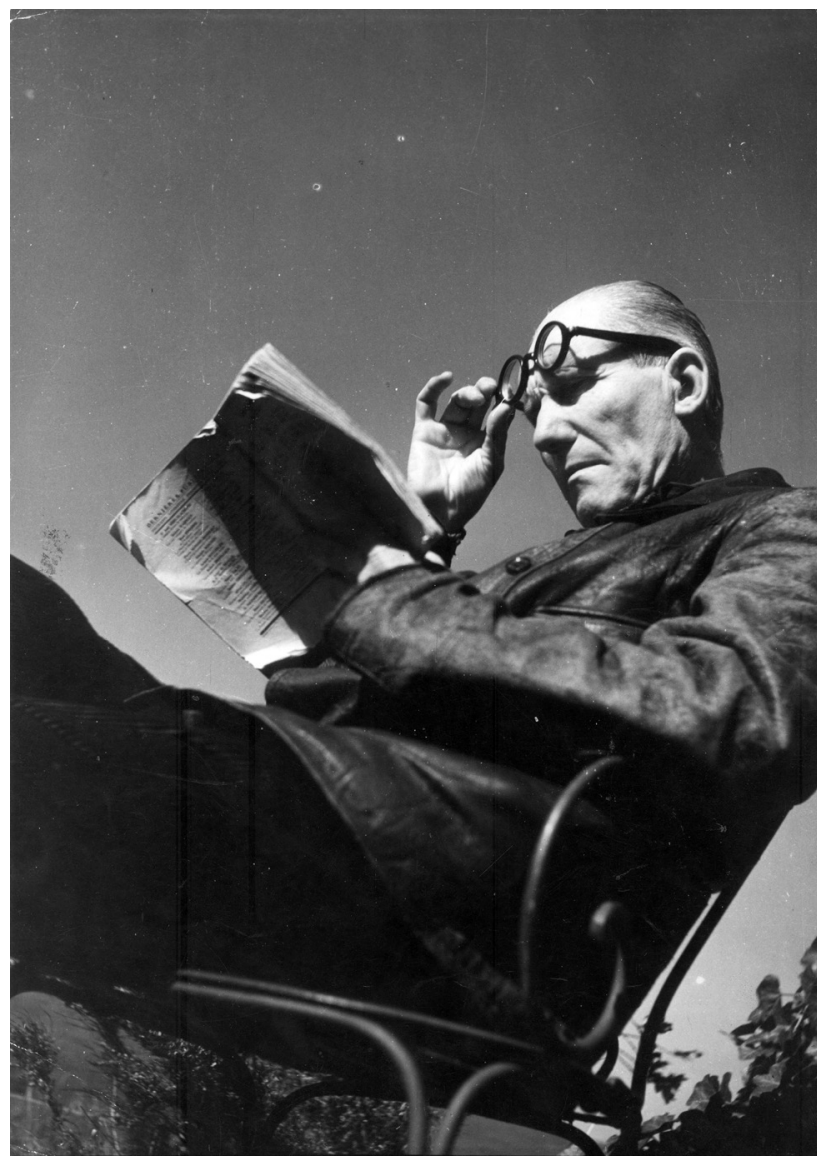

Figura 2 - Fotografia de Le Corbusier por Robert Doisneau, usada na página de abertura da Módulo n¹, 1955. (C) Fondation Le Corbusier, Paris.

Esse trecho é, por certo, um anúncio do que se realizaria nas superquadras em Brasília, cumprindo os postulados dos CIAM em relação à moradia, ou seja, a criação de zonas residenciais em meio a áreas verdes e complementadas por serviços.

No expediente desse primeiro número da Módulo estão agrupados em ordem alfabética os nomes dos fotógrafos que trabalham para a revista: Jean Manzon, José e Humberto Franceschi, Kasmer, Marcel Gautherot e Rafael Landau. A menção à autoria ao longo das páginas dos clichês passou, porém, a ocorrer apenas a partir do segundo número, embora tal procedimento não tenha sido sistemático nem obrigatório, com omissões intermitentes, mesmo em números importantes como os referentes às obras de Brasília. Parece-nos, entretanto, que, ao longo das reportagens, a atribuição a Gautherot é mais freqüente do que aos demais fotógrafos, especialmente porque há muitas matérias "ilustradas" inteiramente por ele, que não se referem à arquitetura, mas a outras temáticas da revista. 
11. Ver a respeito Olivier Lugon (2003). O próprio Le Corbusier, embora empregasse a fotografia em seus livros, subestimou os fotógrafos (como outros arquitetos de sua geração) até encontrar Lucien Hervé em 1950, que promoveu sua obra, trabalhando junto ao arquiteto por 15 anos; a esse respeito ver Nathalie Herschdorfer e Lada Umstätter (2012). Entre as leituras sobre a relação "fotografia / arquitetura”, destaco: History of Photography, vol. 22, n. 2, Summer 1998.

12. Ver Philip L. Goodwin (1943).

13. Ver as pranchas mencionadas em Stamo Papadaki (1960).

14. Para citar apenas alguns exemplos sem atribuição de autoria aos fotógrafos: The Architectural Review, v. 108, n. 644 , ago. 1950 com fotografias de edifícios de Lucio Costa no Parque Guinle; no "Report on Brazil" de outubro daquele ano, n. 646, obras (Pampulha, Pedregulho...) estão sem autor; o mesmo para obras de Reidy, Niemeyer e outros no v. 16, n. 694 ("Report on Brazil") de outubro de 1954. Porém, no numero especial 'Brésil' de L'Arcbitecture d'Aujourd'bui, v. 23, ns. 4243, ago. 1952, muitos fotógrafos já são identificados: Photo Hess, P. Sheier, Aertens, José Medeiros, Lefèvre, Landau, Kazmer, Photo Carlos, Jean Manzon e Carlos Botelho - os cinco últimos figurarão na Módulo; há mesmo uma reportagem sobre o edifício Caramuru, em Salvador, com fotografias atribuídas a Verger. O nome de Gautherot também aparece como autor de fotografias da "Unidade de habitação" de Pedregulho nesse número, como já havia aparecido em: L'Architecture d'Aujourd' bui (edição sobre urbanismo na América latina), n. 33, dez. 1950/jan. 1951; na Domus n. 254, jan. anonimato do fotógrafo de arquitetura era a regra no cenário internacional, tema estudado na literatura estrangeira a respeito das revistas modernistas da vanguarda que circulam fartamente ilustradas desde os anos 1920. Embora responsáveis pela comunicação promocional e difusão das obras dos arquitetos nessas publicações e exposições, os fotógrafos não eram em geral reconhecidos, nem seu trabalho valorizado. Sabe-se que estando a serviço de um arquiteto, eles eram solicitados a produzirem "documentos", a se submeterem a ditames diversos e complexos, específicos a cada encomenda ou campanha fotográfica, sendo, pois, excepcional a "criação sobre a criação", a "criação partilhada", a "foto de autor", ainda mais porque o gênero vista de arquitetura, não era reconhecido "como arte" 11 .

A partir dos anos 1940, quando a arquitetura moderna brasileira começara a ocupar as páginas de livros e periódicos internacionais, a tendência de não citar o nome do fotógrafo em relação a cada clichê permaneceu, podendo seus nomes, todavia, constar, em sumários ou nos textos de apresentação. As fotos raramente fugiam das modalidades clássicas de representação, mas, apesar disso, uma "nova visão" fotográfica da arquitetura surgia esporadicamente em capas, introduções e editoriais, como a tomada em perspectiva oblíqua da fachada noroeste do edifício do Ministério da Educação e Saúde que consta no catálogo que foi um marco para a difusão da nova arquitetura brasileira, Brazil Builds, em $1943^{12}$ (Figura 3). Essa tomada diverge das demais publicadas na obra, marcadas pela impessoalidade do registro documental, pois segue os postulados da Nouvelle Vision, captando de baixo para cima a grelha de brise-soleil, além de destacá-la em detalhe como a solução aos problemas do clima tropical. $\bigcirc$ mesmo ângulo, mas com o perfil do edifício acentuado pela aproximação lou seria a mesma fotografia cortada?) reaparece também sem cachet autoral, em número especial sobre o Brasil de L'Architecture d'Aujourd'hui, em 1952, que traz artigo de Sigfried Giedion, "Le Brésil et l'architecture contemporaine" (Figura 4).

Idêntica visão da tomada em contre-plongé faz parte das pranchas-contato do acervo de Marcel Gautherot sobre o mesmo prédio pertencentes ao Instituto Moreira Salles (a título de exemplo, os contatos 11166 a 11 168), bem como um gros plan do brise soleil (contato n. 11 169), semelhante ao da fotografia em Brazil Builds, e que se repetirá nas pranchas 1 e 5 do livro Oscar Niemeyer de Stamo Papadaki ${ }^{13}$. As similitudes dos ângulos captados por diferentes fotógrafos é um dado da circulação internacional de imagens, e conseqüentemente, das dificuldades de atribuição de autoria na história da fotografia da arquitetura moderna.

Embora, como foi dito, o crédito ao fotógrafo não seja uma prática obrigatória nas revistas de arquitetura até mesmo nos anos 195014, no número especial sobre o Brasil de L'Architecture d'Aujourd'hui, publicado em setembro de 1947, a fotografia do Grande Hotel de Ouro Preto, de Oscar Niemeyer é atribuída a Gautherot. $\bigcirc$ reconhecimento profissional do fotógrafo começa a se afirmar timidamente, na sombra daquele do arquiteto, e embora não haja evidências documentais específicas sobre a relação dos dois (correspondências, entrevistas 


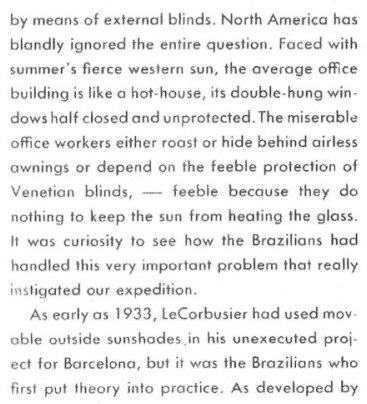
summer's fierce western sun, the average office building is like a hot-house, its double-hung windows half closed and unprotected. The miserable office workers either roast or hide behind airless Venetion blinds, - feeble because they do nothing to keep the sun from heating the glass. It was curiosity to see how the Brazilians had handled this very important problem that really instigated our expedition.

As early as 1933, LeCorbusier had used mov able outside sunshades in his unexecuted proi. ect for Barcelona, but it was the Brazilians who first put theory into practice. As developed by

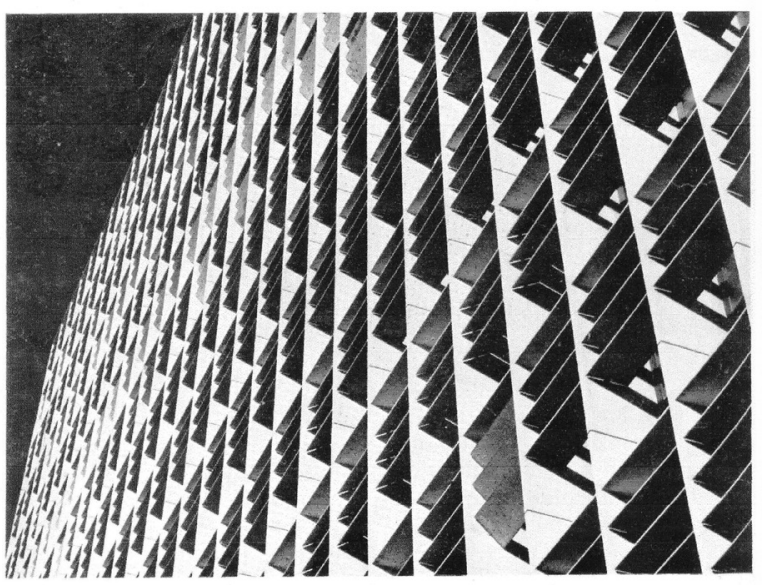

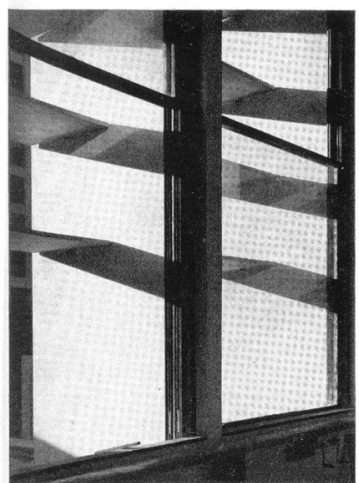

A crank moves the sunshades of the Ministry

of Education.

$$
\begin{aligned}
& \text { Um mecanismo move os } \\
& \text { Ministerio da Educação }
\end{aligned}
$$

the modern architects of Brazil, these externa blinds are sometimes horizontal, sometimes vertical, sometimes movable, sometimes fixed. They are called quebra sol in Portuguese, but the French term brise-soleil is more generally used.

In no case has the sunshade more successfully been integrated with the architecture than in the Ministry of Education and Health. The cool south side exposes its wall of double-hung sash without protection. On the north, however (remember that in Brazil the sun comes from the north), the floors, reduced to thin concrete slabs, are cantilevered out about four feet beyond the window face. Similar vertical slabs, also spaced four feet apart, divide the facade into a gigantic eq-erate of rectangular shapes. The upper pant of each rectangle contains three horizontal 85 a proteger-se escassamente por meio de toldos ou venezianas, proteção fraca porque nada $p$ dem contro os reflexos do sol nas vidraças. E e curioso verificar-se como os brasileiros fizeram face ao importantissimo problema, cujo estudo foi o que animou a nossa viogem.

Já, em 1933, Le Corbusier recomendava o uso de quebra-luzes moveis, externos em seu projeto inexecutado para Barcelona, mas foi no Brasil onde, primeiro, essa teoria se poz em

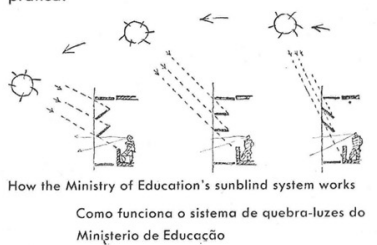

Tais como os arquitetos do Brasil os desenvolveram, esses para-sois externos são às vezes horizontais, às vezes verticais, às vezes moveis, às vezes fixos. Quebra-sol é o nome que se the dá, mas a expressão francesa brise-soleil é mais geralmente usado.

Em nenhum caso, tais engenhos foram integrados de modo mais feliz na arquitetura do que no edificio do Ministerio de Educacão e Saude Púlica, do Rio de Janeiro. O lado sul, mai fresco por menos exposto acha-se isento de proteção. Do lado norte, porém, lé preciso não esquecer que o sol, no Brasil, vem do norte), os pavimentos de espessas lages de concreto estenJa metro e meio da frente da janela.

Semelhantes saliencias verticais, separadas por pouco mais de um metro uma de outra, riscam a fachada, dando-lhe feição de um gigant a foch ada, da gupe-

Figura 3 - Página dupla do prefácio de Brazil Builds. Architecture New and Old 1652-1942, de Philip L. Goodwin, destacando a fachada e detalhe do edifício do MEC, no Rio de Janeiro, protótipo da arquitetura moderna brasileira.

significativas, práticas respectivas de enriquecimento mútuo) - pode-se afirmar que um entendimento criativo se estabelece entre eles a partir das campanhas de registro fotográfico que acabam por resultar em verdadeiros arquivos de projetos. Afinal de contas, de maneira formal ou informal (no mais das vezes...), Gautherot captou os canteiros de obras de Niemeyer de 1942 até pelo menos o inicio dos anos 1960, fornecendo material para a imprensa, editores e exposições, documentando e difundindo, enfim, as obras mais importantes do modernismo brasileiro.

Como observei sobre o anonimato e a circulação, as fotografias se repetiam entre diferentes publicações, pois os fotógrafos colaboravam em revistas de várias nacionalidades, e certas obras e partes delas eram mais retratadas do que outras. É o caso do brise soleil da fachada do edifício do MEC, marco fundador e emblemático da nossa arquitetura moderna que se torna um ícone a partir de Brazil Builds, e que reaparece na capa do número "Brésil" da L'Architecture d'Aujourd'hui, de 1947 (desta feita a foto é atribuída a "Foto Carlos", que mais tarde vai integrar a equipe da Módulo); uma vista geral do edifício figura na capa da Encyclopédie de l'Architecture Nouvelle de Alberto Sartoris, em 1954, no
1951; e em L'Architecture d'Aujourd' bui, n. 52, jan-fev. 1954, nas fotos do jardim de Burle Marx no aeroporto do Rio. No que concerne aos livros, a prática de atribuição das fotografias da arquitetura brasileira se generaliza, como se pode observar em autores como Henrique Mindlin (1956), Stamo Papadaki (1960) e Henry-Russel Hitchcock (1955, que cobre também outros países da América Latina). Porém os fotógrafos (Gautherot entre eles), não são indicados particularmente em cada clichê, mas em lista, no final dos volumes, em relação aos números das páginas em que figuram suas fotos ou junto aos números das pranchas. 
15. Ver Alberto Sartoris (1954).

16. Baudin refere-se ao "empreendimento editorial" de Alberto Sartoris, como uma contribuição que levantou e fixou o mais representativo corpus de referência iconográfica do movimento moderno internacional. O repertório inclui o Brasil, com 379 tiragens, mas 64 são de maquetes e 126 de representações gráficas; a maioria retrata obras até 1953 , e há poucas do final dos anos 1950. Entre os fotógrafos citados estão Hugo Zanella, o arquiteto $\mathrm{G}$. Warchavchik, a agência Carlos, Marcel Gautherot, Michel Aertsens, sendo que há muitas fotografias sem assinatura. Ver Antoine Baudin (2003, p. 199).

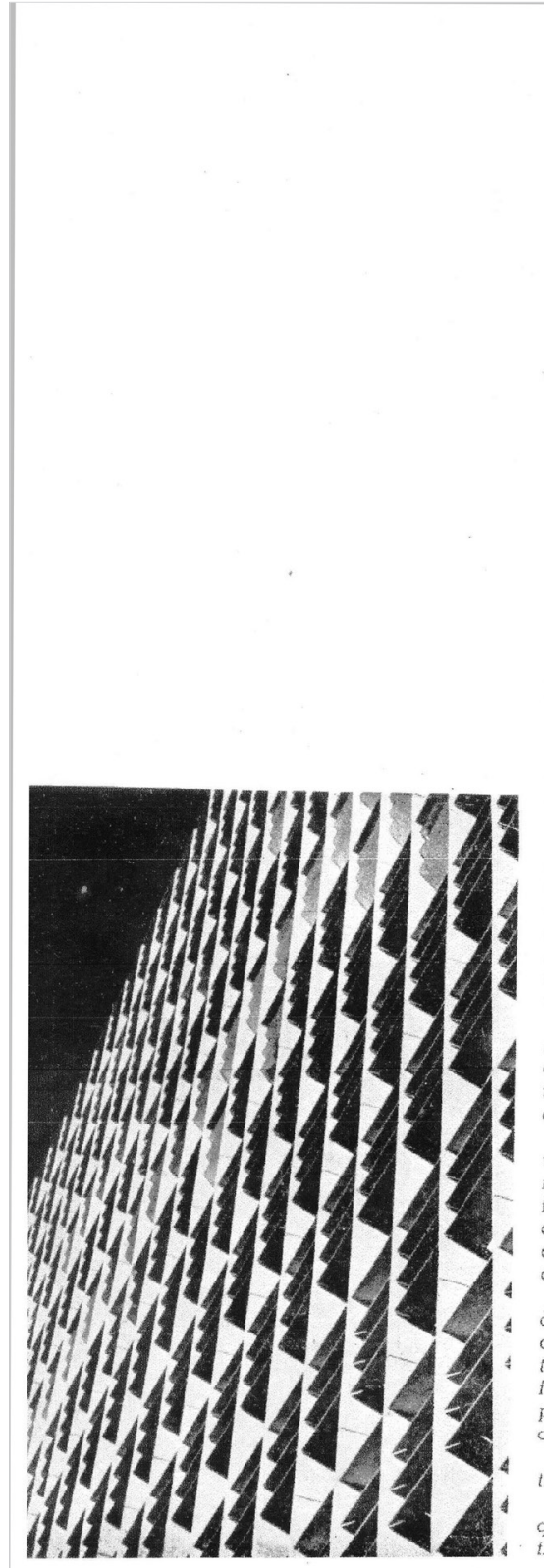

Dans un siècle particulièrement matericliste, il est heureux de cor des eftorts substantiels strccomplissent en des points divers du globe ner à notre énocue un visage qui ne soit pas indigne de lo civilisation A Paris, ou des rencontres d'artistes ou dachilectes sont particulien breuses, il est trop fréguent de constater un certes sont paniculiere.

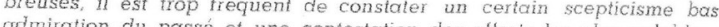
tion con a palables thon contemporaine. Celle atitade passive est des plus dangereuses bon nombre d'années, par diverses publications, nous avons songé a in un tel état d'esprit.

Tout d'abord, nous avons été à pea près les seuls en France a bon combat, mais, comme nul n'est prophète en son pays, notre voix entendue. Ce fut le cas aussi pour Le Corbusier dont l'esprit createnr temps incompris et partois meme touné en dérision. La derniere gue failli ancantir l'Europe semblait aroir Gunihilé la colésion des recher faire place $\alpha$ un etat d'esprit encouragé par l'envahisseur: abandon tives créatrices et retour au passéisme artisticue.

Pendant ce temps, et sans quion s'en soit rendu compte en Euro saient au-delà de l'Atlantique des rélisations substantjelles. Le passi Corbusier à Rio et Íadmirable compréhension des personnalités br telles que Lucio Costa, provoquèrent, dans ce pays, que rien ne prédestir telle évolution, une émulation des plus étonnantes dans les domaines tecture et de lart. Au moment où tout s'eftondrait en Europe, s'édifiai tère de l'Education et de la Santé gráce a M. Gustavo Copanema alors bien daules constructions: la lecon de Le Corbusier eltit non sele prise mois généreusement continué et développere peu considere dans le monde entier comme la terre d'élection de l'a emporaine la plus nouvelle et la plus audacieuse.

Comment dans une temps si court un tel changement $\alpha-t-i l$ pu se comment tant d'architectes de valeur ont-ils pu s'affimer? Nous croyor Texpliquer, dune part par la solide conviction acquise par les archit siliens au cours des années qui viennent de s'écouler. Ils ont travaill dans une direction personnelle. Mais il est évident que ces jeunes arch moins de 45 ons n'auraient pas pu récliser des anvres aussi importi n'avaient pas trouve cupres de certoins services d'Etat et de quelque nclités lappui moral et matériel indispenable. Le Service duetque

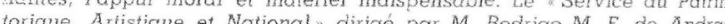
organisme aupres duquel les architectes modernes du Brésil ont toujor des encouragements. $I l$ en est de même pour divers services gouverm qui ont adopté une attitude compréhensive et stimulante. Enfin, le gow brésilien et, en particulier le Ministre des Affaires Etrangeres M. Iodo: Fontoura qui, en dehors de ses hautes fonctions, est cussi un excellen et un homme de haute culture, ont apprécié à sa juste valeur le trava siaste des meilleurs architectes de leur pays.

C'est à M. Joao Neves da Fontoura que nous devons aussi thonne senter aujourd'hui ce numero. Et nous nous devons de dire que linit cet ouvrage remonte aे 1949 et reviem à $M$ Roberto Äsumpcô de Arau taire de I'Ambassade du Brésil à Paris. Chargé des Aftaires Culturelles a été réalisé en constante collaboration avec hui.

Dans ce numéro exceptionnel de "I'Architecture d'Aujourd'hui n vera non pas une répétition du muméro que nous avons publié il y a mais de nombreuses constructions nouvelles deja achevées ou en co fication. Les ceuvres de qualité sont si nombreuses qu'il nous a follu choix et nous n'avons pas loujours pu donner, à chacune d'elles la pla aurait méritée. Malgré cela, nous avons dû doubler le nombre des pages consacrons habituellement à des études anclogues.

En dehors de toutes les considerations propres a larchitecture, il I'honneur du Brésil l'extrcordinaire collaboration qui s'est établie ent chilectes et les artistes de ce pays, en vue de cette synthèse des Artsd lant question et dont il y a encore trop peu d'exemples dans le monde fait appel, jusqu'd présent, à des artistes nationaux, comme Portinari peinture et les revêlements muraux. Burle Marx pour les revêtements e ins et a quelques autres artistes comme on le verra en lisant ces pages. La technique traditionnelle portugaise des Azulejos a été mise a mais avec un renouvellement complet et une franche liberté artis C'est à cet esprit d'équipe et de collohorotion entre orchitectes que nous devons les belles récrisations de Rio de Sao-Panlo, de Bahia, tiba ou de Cataquazes, germination etonnante aui frit rmolimament

Figura 4 - Página do número especial "Brésil" de L'Architecture d'Aujourd'hui, n 42-43, 1952, com o editorial de André Bloc "Ayons confiance dans l'architecture contemporaine". Fotografia sem atribuição de autoria.

volume sobre "Ordre et Climat Américains"15 (note-se que entre suas 800 ilustrações quase trezentas pranchas sem atribuição de autoria exibem obras brasileiras ${ }^{16}$ ). Voltarei à questão dos créditos mais adiante, ao comentar as reportagens com fotografias de Marcel Gautherot na Módulo. 
O lugar da fotografia como reprodução impressa é preponderante em todas as rubricas da revista Módulo, da capa à publicidade, passando pelas reportagens principais, cujas temáticas respondem aos interesses dos anos 1950, voltados, além da arquitetura, para a cultura popular e as artes plásticas em suas manifestações diversas. Tal variação fica evidente no exame do sumário do primeiro número, que reúne artigos sobre arquitetura brasileira (destacando obras marcantes como o conjunto do Ibirapuera), bonecas Carajás (com fotos de Gautherot, sem crédito), capelas rurais do Brasil (monumentos tombados como patrimônio histórico nacional são frequentes nos primeiros números da Módulo), casas sobre palafitas (a arquitetura vernacular foi um dos temas prediletos de Gautherot), e outros assuntos como o trabalho do escultor-arquiteto José Souza Reis, os jardins de Burle Marx, e atualidades arquiteturais como projetos de residências de arquitetos modernistas, em fotografias sem atribuição.

Nas revistas de então, as imagens escapavam completamente das mãos dos fotógrafos, submetidas a enquadramentos arbitrários, a cortes, a formatos diversos e a justaposições, adequando-se às escolhas dos diagramadores ${ }^{17}$. A manipulação de fotos também está presente no layout das capas da Módulo, muitas das quais desenhadas ou compostas sob "arranjo" de arquitetos e/ou designers, como Arthur Lício Pontual, Athos Bulcão, Glauco Campelo e, mais tarde, Goebel Weine. Se esses estão devidamente identificados como autores do design gráfico, a menção ao fotógrafo, como foi dito, é esporádica nos primeiros números. Em geral as capas destacam detalhes de arquitetura de obras significativas, mostradas nas páginas internas do número, tirados de fotografias e montados em fundo com cores primárias que podem também velar a imagem $\mathrm{p} / \mathrm{b}$.

A capa da Módulo no 1 traz, por exemplo, os pilotis robustos de concreto bruto em forma de "V", recortados de fotografia sem atribuição do Palácio da Agricultura do Parque do Ibirapuera (Figura 5), que faz parte de artigo deste número sobre a "Arquitetura Brasileira", aí denominada como "moderna e nacional", demonstrando que a revista era a priori uma empresa engajada por ela, como atesta o cachet na parte inferior das capas: "Brasil Arquitetura".

A arquitetura moderna era, assim, o tema central das imagens das capas da revista, mas essa arquitetura era suplantada, algumas vezes, por outras representações, como a dos monumentos patrimoniais: a capa da Módulo n 12 (fevereiro de 1959) mostra fachada em Ouro Preto, em layout de Pontual sobre fotografia que recebe o efeito moiré, atribuída a Otto Stupakoff; a da Módulo nº 23 (junho de 1961) estampa fotografia da igreja de São Miguel das Missões, sem menção de autor, mas que poderia fazer parte das séries de Marcel Gautherot no Arquivo Noronha Santos ${ }^{18}$, e a capa da Módulo n² 29, de 1962, exibe um detalhe da Fazenda Colubandê, no município de São Gonçalo, no Estado do Rio. Essas duas últimas capas pertencem, aliás, à fase em que as dimensões da revista já estavam reduzidas e quando ela não apresentava mais o cuidado gráfico e o
17. Sobre a história da subordinação da fotografia à criação tipográfica, ver Olivier Lugon (2007b). Vimos em pesquisas anteriores que o nome de Gautherot aparece em cartão da exposição "Affiche/Photo/Typo", de 1935, em Paris - mas, neste cartão, uma pastilha precede o nome dos fotógrafos: Verger, Boucher, Zuber e Feher; Gautherot estaria entre os designers e decoradores que montaram a exposição, como Robert Pontabry, que em 1936 faria com ele o projeto da sala de projeções e conferências do Museu do Homem. Ver reportagem na L' $A r c b i t e c t u r e$ d'Aujourd'hui, de junho de 1938.

18. Na Série "Inventário" desse arquivo, no IPHAN, no Rio de Janeiro, Lygia Segala encontrou grande número de fotografias de Gautherot, inclusive negativos, sobre as ruínas dos Sete Povos das Missões. Cf. Lygia Segala (2007b, p. 223-231). Lembro outra exceção em que a arquitetura não está na capa da Módulo: trata-se do n. 14 (1959) em que o layout é novamente de Pontual, que usa livremente a silhueta de uma escultura de Mario Cravo, tirada de fotografia de Franceschi. Pontual desenhou capas também para outras revistas, como a Brasília (da Cia. Urbanizadora da Novacap), que atribui fotos da capital em construção a Gautherot, a Franceschi, e especialmente a Mario Fontenelle, em 1958 e 1959 . 
conteúdo variado dos primeiros anos; chega-se mesmo a não registrar o crédito a Gautherot em muitas fotografias da maior relevância de suas séries sobre Brasília nas páginas internas (como na Módulo n²6, de dezembro 1961, da
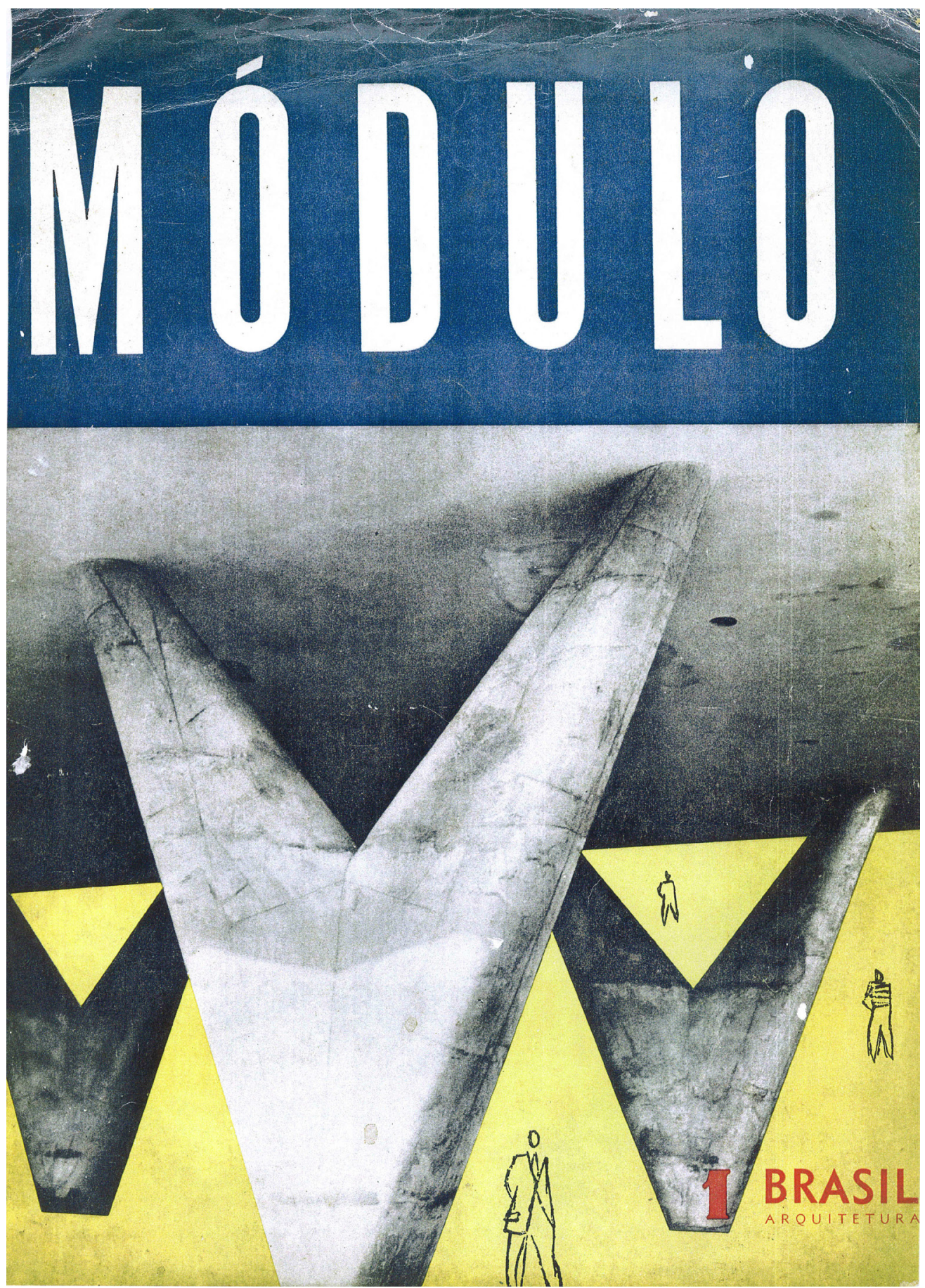

Figura 5 - Capa da Módulo no 1, março de 1955: "arranjo" de Athos Bulcão com pilotis recortados de fotografia sem atribuição. 
qual vou tratar mais adiante), embora neste caso, a capa seja atribuída a ele (Figura 6).

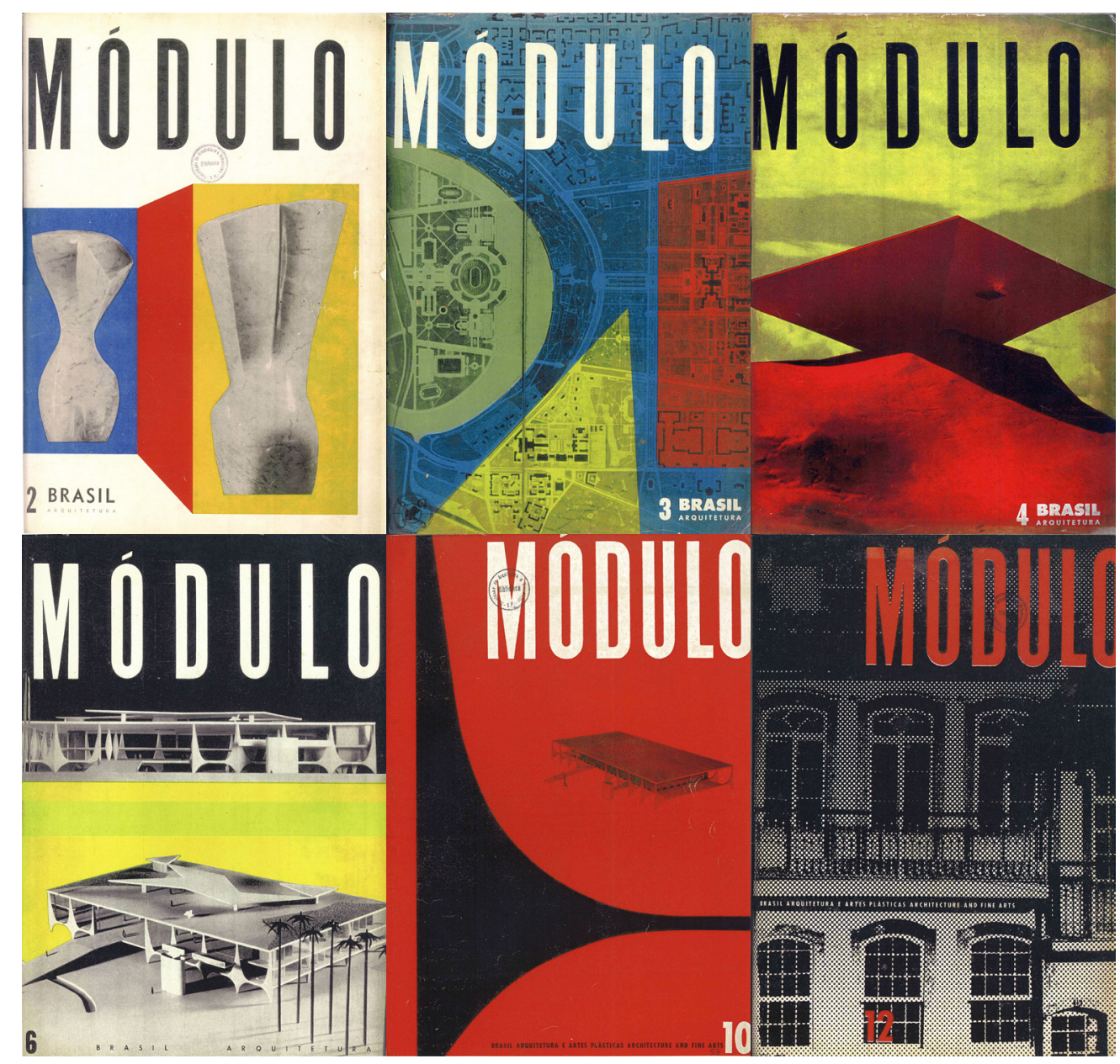

Figura 6 - Capas da Módulo na "primeira fase", entre 1955-1959

A eficácia mediática da fotografia se associa, ao longo das capas e páginas, a outras linguagens da produção arquitetônica - desenhos de plantas e detalhes de perfis, esboços e muitas fotos de maquetes -, para tornar os projetos inteligíveis e a recepção positiva, das novas formas da arquitetura moderna, afirmando e reafirmando imagens que vão conferir o estatuto de ícones a certos edifícios e às suas partes - penso aqui, no Palácio da Alvorada e em suas colunas que se repetem em tiras horizontais num "arranjo" de Athos Bulcão na capa da Módulo n $7^{19}$ (Figura 7).

Entre as capas em que fotografias retrabalhadas são atribuídas a Gautherot, destaca-se a da Módulo n 13; nela, Pontual usa livremente, na composição, um contato do fotógrafo ${ }^{20}$, introduzindo cores que modificam seu efeito (Figura 8). Esse contato pede comentários sobre apropriações e persistências
19. Sobre a associação de práticas híbridas da arte/ design/arquitetura no trabalho desse designer, ver Rafael Miura Bonazzi (2010/2). A Módulo n. 10, de agosto de 1958 , traz reportagem sobre Bulcão como um dos principais colaboradores de Niemeyer na decoração de construções para Brasília, com imagens coloridas que destacam detalhes de suas obras, do vitral ao azulejo, e pequenas fotos $\mathrm{pb}$ da Igreja de N. S. de Fátima e da capela do Palácio da Alvorada que poderiam ser de Marcel Gautherot; na Módulo n. 14, há uma reportagem sobre o escritório da Construtora Rabello S.A., em que um painel é composto por Bulcão "com fotografias de M. Gautherot".

20. Destaco sete contatos de detalhes das estruturas em construção (ns. 1955719663) de uma das pranchas-contato do acervo de M. Gautherot; ver Heliana Angotti-Salgueiro (2008, p. 42). 
21. Ver a respeito meu texto "Formação profissional de Gautherot: arquitetura e fotografia" em Heliana Angotti-Salgueiro (2007b).

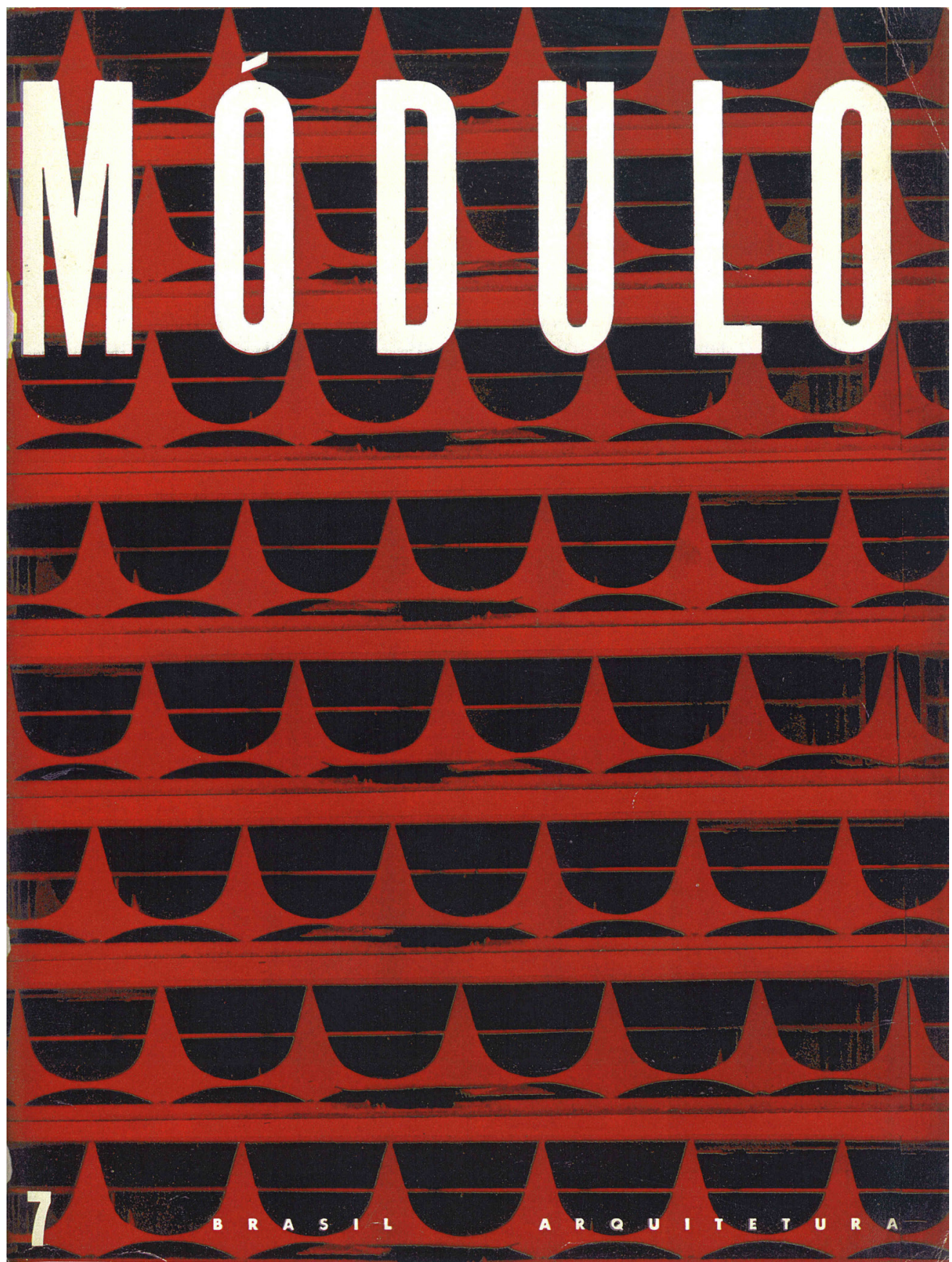

Figura 7 - Capa da Módulo n 7, fevereiro de 1957.

de linguagens da Nova Fotografia europeia dos anos 1920-1930, presentes na obra de Gautherot em Brasília, no final dos anos 1950: no caso, a foto é abstrata e inscreve-se no Construtivismo; há outros contatos nas páginas da Módulo, próximas da Nova Objetividade, outra linguagem vivenciada por Marcel Gautherot em sua juventude antes de vir para o Brasil ${ }^{21}$. Na primeira, utilizada 


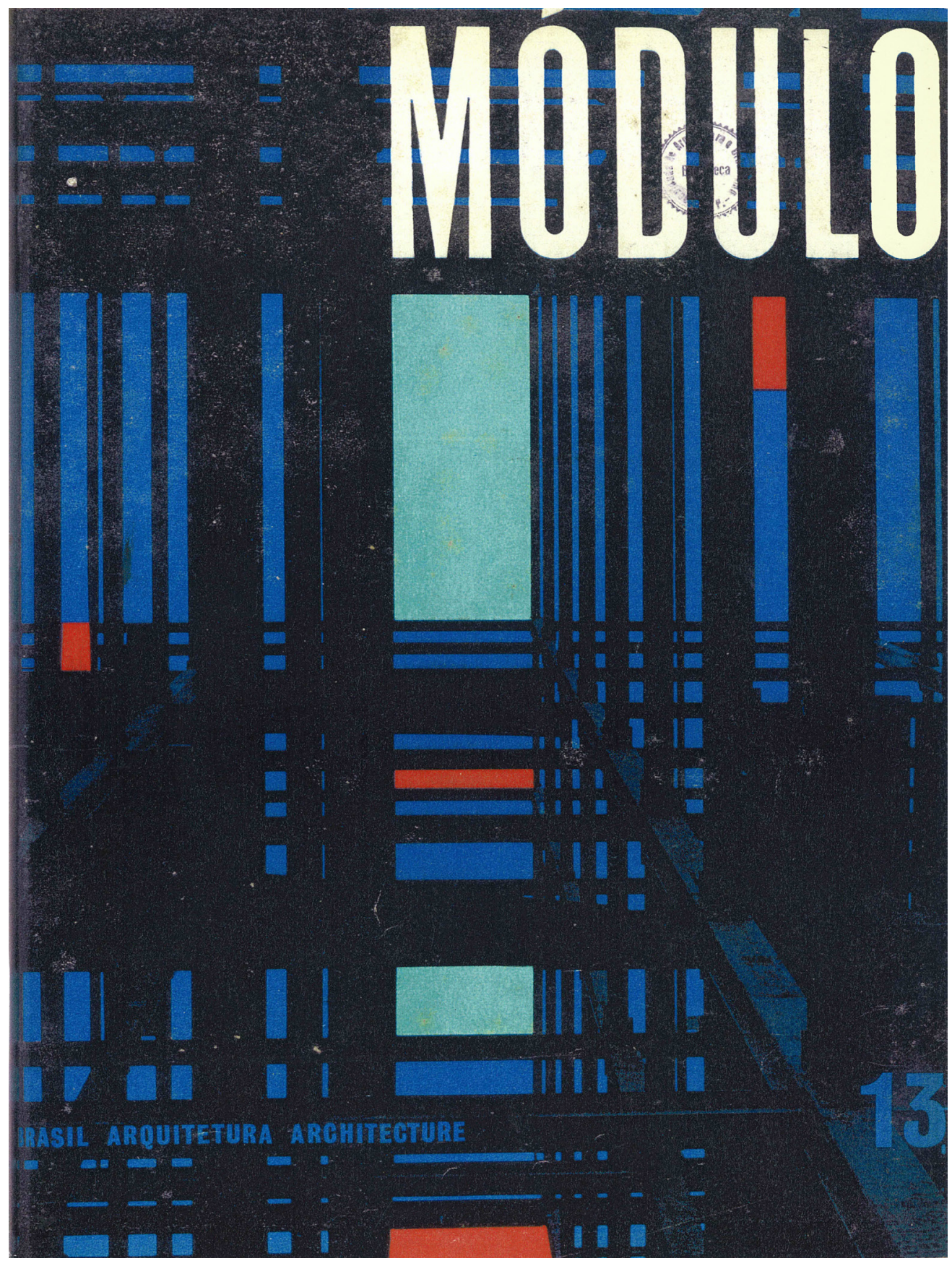

22. Cf. Andreas Haus (1997, p. 84-91). Entre os arquitetos-fotógrafos que assimilaram as experiências formais da vanguarda se concentrando nas estruturas e linhas da arquitetura, destaca-se Sigfried Giedion em seu clássico Bauen in Frankreich..., de 1928 (1995).

Figura 8 - Capa da Módulo n 13, abril de 1959: "arranjo" de Arthur Lício Pontual a partir de fotografia de Marcel Gautherot.

nessa capa da Módulo n 13, o fotógrafo isola a trama dos ferros armados da obra em construção, capta os aspectos tectônicos e construtivos das vigas num espaço indefinido em perspectiva e afirma, assim, o valor da visualidade parcial arquitetônica sobre o registro documentário arquitetural. A fotogenia ${ }^{22}$ formalista 
23. Ver Heliana Angotti-Salgueiro (no prelo).

24. Cf. as introduções aos textos selecionados por Olivier Lugon (1997, p. 149, 159). E, ainda, Andreas Haus (1997), e o capítulo "La nouvelle photographie dans les revues des années trente" de Hélène Jannière (2002, p. 90-103).

25. Ver figura 23, contato 11.211, em Heliana Angotti-Salgueiro (2007b).

26. "Durante muito tempo a criação em fotografia foi identificada à fragmentação: é recortando uma parte arbitrária em um conjunto maior que o fotógrafo proclama sua capacidade de transfigurar mais do que de duplicar a realidade". Observação de Olivier Lugon (2003, p. 50). de partes não remete à imagem real do edifício, mas desprende-se dele e se inscreve nos códigos da fotografia experimental da vanguarda, tema sobre o qual já desenvolvi um estudo específico ${ }^{23}$. Em relação a contatos desta série Construtivista, emprego a noção de "fotogenia" com o sentido que os textos dos anos 1930 the conferiram: "o que o olho mesmo é incapaz de ver e que somente a fotografia vai lhe mostrar", ou seja, "é fotogênico o que apresenta um forte efeito estético em fotografia (...) pelo efeito da luz e o jogo de detalhes". A "evidência fotogênica" seria então a escolha de mostrar a beleza técnica de materiais (no caso o ferro armado para receber o concreto), com suas superfícies preto-brancocinza, graças às luzes, reflexos (que desaparecem na composição de Pontual), e o enquadramento em gros plan das armações metálicas fragmentadas do todo ${ }^{24}$. Na fotografia que deu origem à capa da Módulo n 13 , ou em outras tiradas nos canteiros de obras de Brasília em construção, e mesmo muito antes - é o caso dos detalhes dos respiros no teto-terraço do edifício do Ministério da Educação e Saúde no Rio, em $1946^{25}$-, Gautherot é livre para exercer escolhas e mostrar sua capacidade criativa fora dos parâmetros documentais e informativos da foto de encomenda.

Da segunda linguagem, ainda a remeter aos seus anos de vivência europeia no âmbito da fotografia de arquitetura, destaco os contatos em que ele se aproxima das formas para enquadrar apenas uma parte delas - caso das cúpulas do Congresso Nacional -, captando-as sob um monumentalismo brutalista que não possuem na realidade, e submetendo o volume cortado a fortes contrastes de luz e sombra - a aproximação e a fragmentação inscrevem-se na linha da Nova Objetividade alemã, familiar a Gautherot, e permite ao fotógrafo reivindicar sua criatividade em relação aos seus pares que trabalhavam também para a revista ${ }^{26}$. Essa visão fragmentária de volumes puros e contrastados das cúpulas côncava e convexa aparece no número especial sobre Brasília de L'Architecture d'Aujourd'hui em 1960, no artigo de Oscar Niemeyer, "Mes expériences à Brasília" Itraduzido da Módulo), e na Módulo n 18 e n 21 , em página inteira, no mesmo ano, não figurando, porém, como imagem de capa (Figura 9)

Há apenas um exemplo de fotografia semelhante, na linha da Nova Objetividade, usada na capa da Módulo n 4, sem identificação de autoria - tratase da maquete do Museu de Arte Moderna de Caracas - que serve de base ao arranjo gráfico do designer Athos Bulcão. Experimentos visuais como esses que privilegiam ora a visibilidade abstrata da estrutura material, ora o volume espacial do objeto, em detrimento de sua imagem convencional, afirmam uma subjetividade irreal e mesmo intemporal e descontextualizada da arquitetura, e confirmam o estatuto de autor ao fotógrafo.

A manipulação de clichês fotográficos, bem como sua combinação com maquetes, esboços, perfis, caracterizadas por um design cuidado, é empobrecida nas capas a partir da Módulo n 16, quando não há mais a composição ou os "arranjos" anteriores, mas apenas uma ou mais fotografias pb com uma cor sobreposta, ou a fotografia de maquete combinada a esboço de obras a serem 


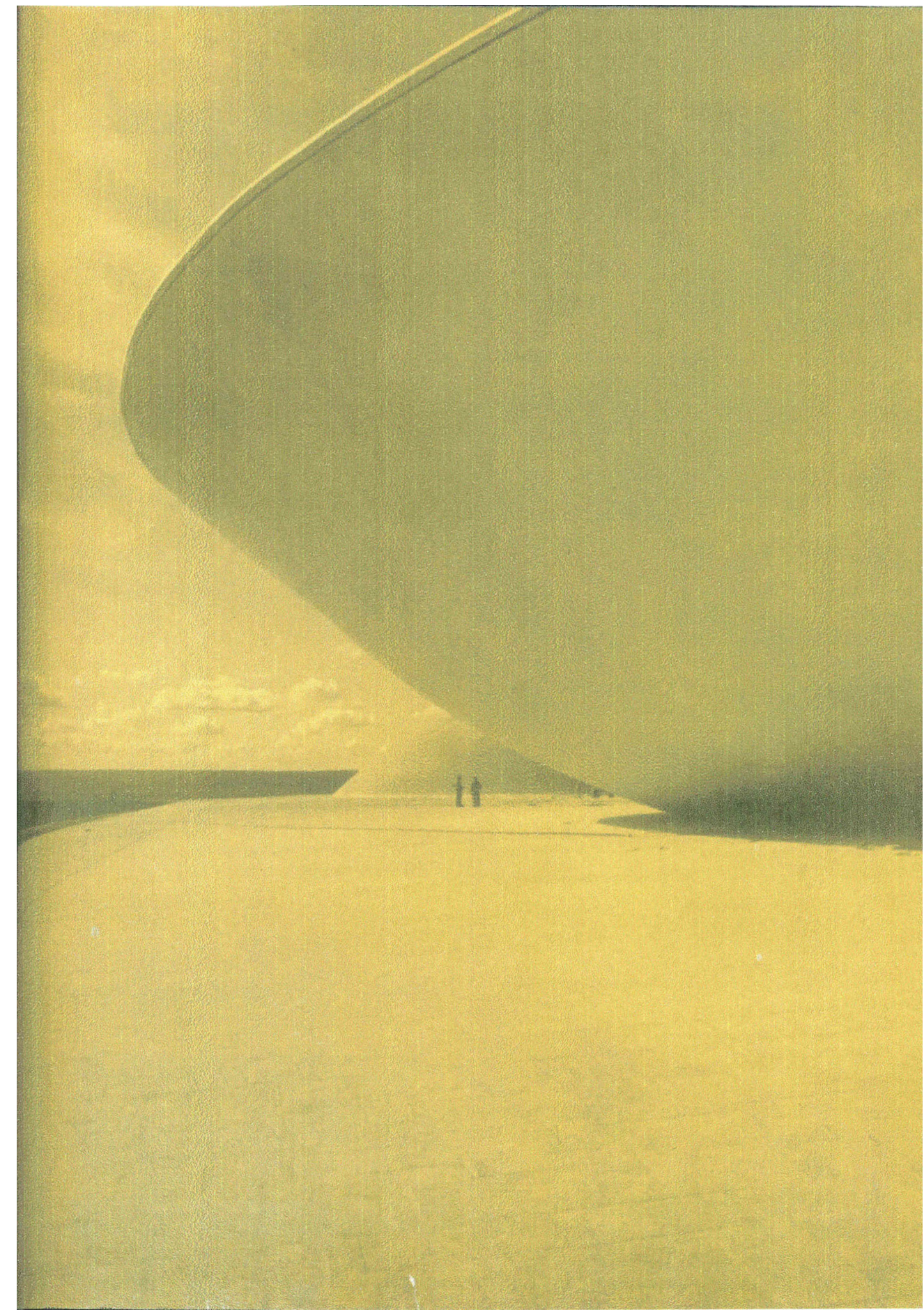

Figura 9 - Gros plan da cúpula invertida do Congresso Nacional por Marcel Gautherot, em Módulo n 18, junho de 1960, no artigo "Minha experiência de Brasília", de Oscar Niemeyer; a mesma fotografia reaparecerá em outro artigo do arquiteto, "Forma e função na arquitetura", Módulo n 21 , dezembro de 1960. 
27. O ensino da fotografia se desenvolveu na Alemanha dos anos 1920 nas classes de artes gráficas e de criação publicitária, e fotógrafos foram vistos muito tempo como "fornecedores" de imagens para as revistas; daí a importância e o reconhecimento autoral dos designers e tipógrafos sobre os fotógrafos. Cf. Olivier Lugon (2003), que traz ainda significativa bibliografia sobre a questão. Observo uma grande semelhança entre as propagandas e o projeto gráfico da Módulo em relação à francesa L'Architecture d'Aujourd'bui, que mantinha um correspondente brasileiro desde 1936.

28. Ver Heliana Angotti-Salgueiro (2005a); trata-se de artigo que faz parte de dossiê que coordenei com Lygia Segala durante a vigência de nossa pesquisa para The Getty Foundation. realizadas, como na Módulo no 17 (Figura 10). Nos artigos internos, a fotografia também vai perdendo a importância que tinha nos primeiros anos da revista, com raras exceções em artigos especiais assinados por Niemeyer, por exemplo, no n 26, de dezembro de 1961, comentado mais adiante, que traz significativas tomadas de Marcel Gautherot.

Após as capas, entram as páginas publicitárias, em geral, dispostas antes da página do expediente - com o conteúdo, nomes de diretores, de correspondentes, fotógrafos, autores de layout, e informação sobre a periodicidade (de dois a cinco números por ano) -, ou intercalando profusamente os artigos; elas ocupam muitas vezes quase a página inteira com boas fotografias sem atribuição, de obras da nova arquitetura em curso, ou já realizadas por grandes construtoras e empresas consorciadas - caso do Conjunto Juscelino Kubistchek em Belo Horizonte ou da construção do pavilhão hoje conhecido como "Oca", no Parque Ibirapuera (Figura 1 1). Além das construtoras que, especialmente por ocasião das obras de Braślia, propagam suas realizações utilizando fotografias, os anúncios cobrem novos materiais de eleição do moderno, como pastilhas de vidro para revestimentos (Vidrotil), o mobiliário contemporâneo (da empresa Oca), as firmas de fundações (Geotécnica), os elevadores, que confirmam a fase de verticalização das cidades ("O Rio, como as grandes capitais, sobe com Otis"), enfim, informam sobre as empresas atuantes neste período desenvolvimentista da indústria ligada à construção civil em plena atividade, graças à renovação urbana e arquitetural do país. A relação texto/imagem confirma a primazia da reprodução fotográfica a serviço da imprensa, e submetida ao trabalho ora criativo, ora banal, do grafismo publicitário moderno ${ }^{27}$. Essas considerações constituem apenas uma introdução ao projeto gráfico e às estratégias visuais da revista, a serem aprofundadas.

Da importância de circuitos e contextos na produção fotográfica de Gautherot, e das lacunas de pesquisas sobre periódicos

Em 2004, ao examinarmos a Módulo e outras revistas e livros a procura de fotografias de Gautherot entre 1940-1960, duas questões vieram à tona: a primeira, mais geral, partia de uma constatação que me incomodava desde as pesquisas que realizei sobre o século XIX relativas às lacunas da historiografia sobre a imprensa periódica no Brasil, às carências de metodologia sistemática de análise interna do objeto-revista ele mesmo (como se organiza, sua dimensão material, etc...), ao levantamento de repertórios e inventários de iconografia que neles figurava, e, especialmente, à ausência de estudos biográficos sobre seus responsáveis e colaboradores. Questão que se liga à segunda, de ordem histórica e cultural, que coloca o objeto nos seus contextos e confirma a partilha de linguagem, a circulação da imagem na imprensa ilustrada, a transferência de modelos, e o alcance dos discursos veiculados - lacunas que respondemos no caso do papel de Gautherot na construção e difusão das representações do Brasil moderno: é assim que, a partir dos anos 1930, periódicos são porta-vozes privilegiados de "uma nova gramática visual" 
centralizada na vida cotidiana do homem-personagem, dos "tipos e aspectos" de regiões do país ${ }^{28}$.

Em relação à Módulo, anunciei no início deste texto que a expressão fotográfica de Gautherot cobre temas diversos, e não apenas a arquitetura - sabe-se que no seu acervo, a proporção de fotografias relativas à representação regionalizada

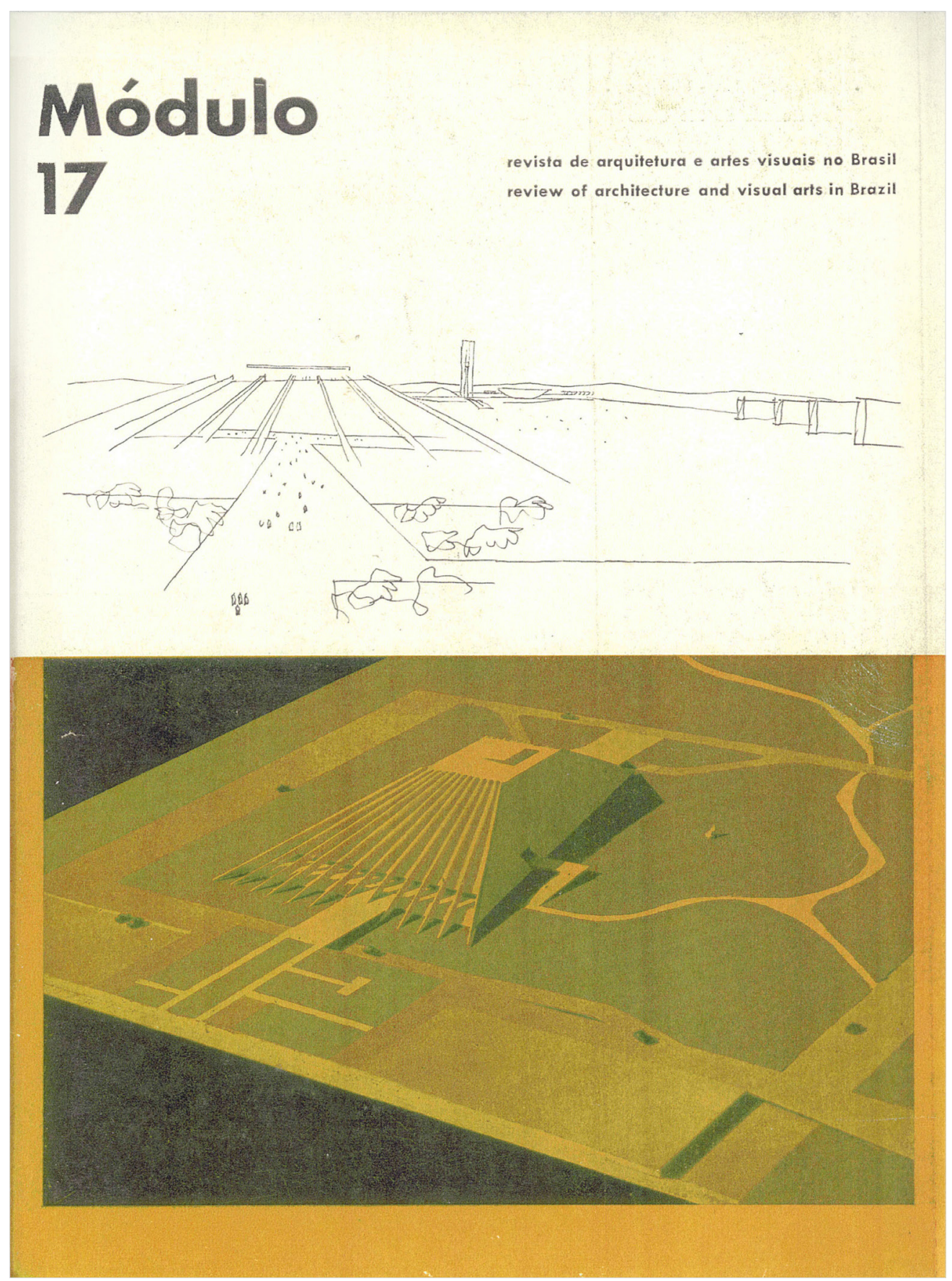

Figura 10 - Capa da Módulo n 17, abril de 1960.

Annals of Museu Paulista. v. 22. n.1. Jan.-Jun. 2014. 
29. Nos expedientes da Módulo, nos números 1 ao 27 , de 1955 a 1962, consta o nome de Marcel Gautherot entre os de outros fotógrafos - alguns se mantêm como o de Jean Manzon (cuja experiência anterior com fotorreportagem na Paris Match e Life é conhecida e não nos interessa tratar aqui), e que no segundo número já aparece como pessoa jurídica, J. Manzon Ltda; aliás, as fotografias de Jean Mazon, que não assina nenhuma foto na Módulo, diferem do trabalho de Gautherot, pois inscritas sobretudo num fotojornalismo sensacionalista que este detestava; raras exceções os aproximam - a exemplo, as fotos atribuídas a Manzon, na reportagem de José Lins do Rego, "L'Homme et le paysage", em L'Architecture d'Aujourd'bui, n. 42-43, 1952, na mesma linha dos "tipos e aspectos". Ao longo dos números da Módulo, outros fotógrafos colaboradores são citados no expediente: Foto Carlos, Carlos Botelho, Flávio Damme Alberto e Garbocci, sobre os quais, ao que saiba, ainda não existem estudos monográficos de peso.

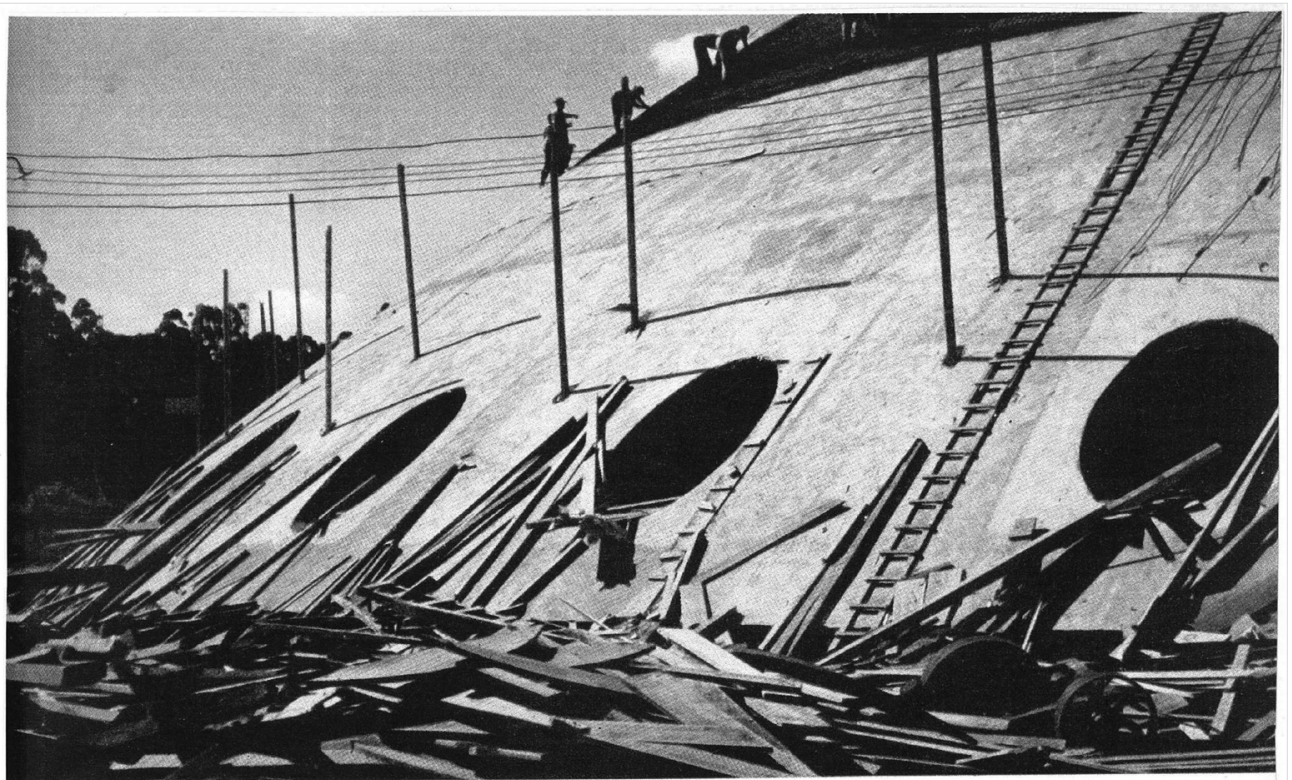

\section{MONTEIRO, WIGDEROWITZ \& MONTEIRO, LIDA.}

$0 .^{\circ}$ andar

el. 36-6590

ão Paulo

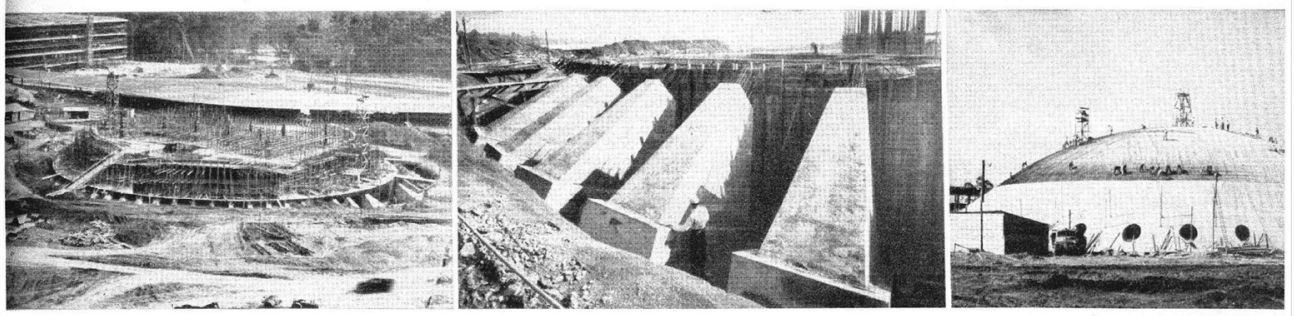

Figura 11 - Página publicitária da "Oca" em construção, projeto de Oscar Niemeyer, Parque Ibirapuera, São Paulo. Módulo n 1, março de 1955.

do trabalho chega a suplantar em número as relativas à arquitetura moderna. Os fotógrafos transitam em vários campos e órgãos de divulgação, daí as trocas e os itinerários fotográficos que coincidem, cristalizando, por extensão, "inter-iconicidades" visuais, questão que foi central na pesquisa que realizamos com o apoio da The Getty Foundation. A comparação de linguagens é dificultada (mas não impossível) pelo fato da maior parte das fotografias não receber atribuição ${ }^{29}$, - constatamos que isto é recorrente nos periódicos que tratam da arquitetura moderna. Passemos, então, aos comentários sobre essas duas questões. 
No Brasil não se conhece uma catalogação, ou um inventário sistemático das imagens que figuraram em diferentes periódicos (especializados em arquitetura e em outras áreas), fonte de pesquisa histórica sem equivalentes sobre a cultura do século XX. Seria necessário, primeiramente, reconstituir séries e coleções para se chegar à sistematização de bancos de dados onomásticos com as notas biográficas dos fotógrafos de revistas, localizar seus arquivos, classificá-los inventariando as produções, temas e linguagens específicas. Embora muitas fotos já sejam reconhecidas como ícones visuais, não há uma sistematização de dados ao alcance do pesquisador - o caminho das pedras é a regra, dada a fragmentação e perda de coleções e de arquivos de revistas ${ }^{30}$, sem mencionar que a maior parte das fototecas, fundações, museus e institutos do país não dispõem de um corpo fixo de pesquisadores, ou quando dispõem, nem sempre há interesse em somar esforços ${ }^{31}$. Porém, a título de exemplo, ao trabalhar o acervo fotográfico de Pierre Monbeig, tive oportunidade de acompanhar discussões e levantamentos na França e participar de publicações sobre bancos de imagens em geografia, e estudos de metodologia de análise crítica de periódicos nessa área ${ }^{32}$.

Apesar da existência de trabalhos recentes, inclusive sobre periódicos que divulgam a arquitetura moderna brasileira ou sobre fotógrafos em particular ${ }^{33}$, desconheço a existência de um banco de imagens que reúna todos os profissionais nacionais e estrangeiros, com dossiês devidamente organizados sobre os edifícios mais retratados, datas e dados sobre os múltiplos usos das fotos. Filiações, similitudes, diferenças, circulação, tiragens e migração das fotos para outros circuitos, inclusive os internacionais que são importantes desde o começo dos anos 1940, fariam parte de tais levantamentos. Falta uma genealogia das reproduções sucessivas, fenômenos de empréstimo e de persistência de modelos relativos a uma história da fotografia.

As lacunas e carências de pesquisas estendem-se àquelas relativas às trajetórias de formação dos fotógrafos, sendo imprescindível ir além das generalidades das cronologias, e buscar, pela pesquisa aprofundada e sem fronteiras disciplinares e geográficas, afinar contextos de formação que possam se ligar à obra futura. Elementos de biografia, de percurso institucional e de relações profissionais informais devem se associar na identificação e comentário sobre as fotografias. Antes da pesquisa que realizamos sobre Marcel Gautherot (que resultou na exposição e catálogo mencionados), afirmava-se seu ingresso na École Nationale des Arts Décoratifs de Paris nos anos 1920 e seu interesse pela Bauhaus, mas não se conheciam dados que comprovassem essa escolaridade, nem declarações dele a respeito da arquitetura moderna. Apuramos então, nos Archives Nationales, que Gautherot estava inscrito na ENSAD entre 1925-1927, com frequência lacunar e restrita ao atelier de arquitetura, e localizamos o único e inédito discurso seu sobre "L'Architecture Française", proferido em Sohlberg durante um congresso franco-alemão de jovens, em 1930, que deu pistas para conhecer suas ideias na área; publicado em um obscuro periódico do entre-guerras, Notre Temps, esse texto evidenciou algumas de suas leituras (como Urbanisme de Le Corbusier) e sugeriu matrizes e referências do pensamento do futuro fotógrafo.
30. Busquei o paradeiro do arquivo da Módulo junto à Fundação O. Niemeyer no Rio, que me respondeu nada saber a respeito. Sem esse arquivo, não é possível reconstituir dados sobre tiragens, assinantes formas de divulgação da revista, contratos de trabalho, pagamento dos fotógrafos, acervo de originais correspondências, etc.

31. Após a realização de uma Jornada de Estudos sobre "Patrimônio Fotográfico e Coleções", que coordenei com Solange Ferraz de Lima no Museu Paulista em dezembro de 2007, encaminhei um projeto ao Instituto de Estudos Avançados da USP e consultei representantes da área de outras instituições sobre "Patrimônio fotográfico brasileiro - levantamento de coleções públicas. Políticas de preservação, catalogação, acesso e difusão", mas o apoio não se concretizou.

32. Ver Heliana Angotti-Salgueiro (2001) e meu capítulo "Do Arquivo ao Banco de Dados. Documentos textuais e iconográficos" em Heliana Angotti-Salgueiro (2006). Nessa temática, agradeço a assistência de Didier Mendibil, autor de estudos sobre iconologia geográfica; sobre sua produção, ver especialmente Didier Mendibil (2005, 2006).

33. Ao retomar a comunicação que deu origem a este texto, encontrei trabalhos sobre esses campos, das quais destaco as de Maria Beatriz Camargo Cappello, (2005), em que, apesar do levantamento documental significativo em revistas estrangeiras, a autora não desenvolve análises especificas das fotografias que, aliás, não vão além de 1954; e de Sonia M. Milani Gouveia (2008a, 2008b).

34. Localizamos na fototeca do Museu do quai Branly 
em Paris, 29 clichês inéditos de Marcel Gautherot feitos no México e colados em fichas de identificação seguindo os códigos de classificação do Museu do Homem, dos quais alguns fazem parte do acervo do IMS; identificamos ainda mais fotos suas dessa viagem, em publicações como o álbum Photographie AMG e as revistas Paris Magazine, Voilà e Cahiers d'Art. Ver Heliana Angotti-Salgueiro (2007b). Em exposição sobre Manuel Álvares Bravo, no IMS, no Rio de Janeiro, em 2011, foram incluídas algumas dessas fotografias de Gautherot, mas nenhuma menção foi feita aos dados da pesquisa que levantei com Lygia Segala em 2004-2006, que possibilitou a mencionada identificação das fotos feitas no México. Ver Lygia Segala, "A viagem ao México - primeira reportagem fotográfica", in Heliana Angotti-Salgueiro (2007b).

35. Considerações sobre séries nas pranchas-contato de Gautherot foram desenvolvidas em Angotti-Salgueiro (2007), especialmente por Olivier Lugon (2007c), tendo sido citadas em obra recente sobre Lucien Hervé, fotógrafo de Le Corbusier; ver Béatrice Andrieux/ Quentin Bajac/Michel Richard/Jacques Sbriglio (2011, p. 11-16).

36. Retomo nos parágrafos anteriores algumas questões presentes em Heliana Angotti-Salgueiro (2013b).
Não se faziam tampouco relações precisas entre o meio freqüentado por Gautherot em Paris e sua provável formação fotográfica, nem se detectavam traços das experiências vividas na Europa em sua obra, dez e vinte anos depois, no Brasil. Por outro lado, pouco acrescentava afirmar que ele participara da instalação do Museu do Homem em 1936 e da Exposição de 1937, se carecíamos de um conhecimento sobre o ideário e práticas daquele museu, e sobre o ambiente cultural e fotográfico da Paris de seu tempo, dos contextos precisos de que participou, daquela exposição e de revistas em que publicou. A título de exemplo, a valorização do regionalismo e da cultura material, tão presentes em publicações e no próprio evento parisiense de 1937, sugere que seu olhar já estava preparado para registrar o folclore, os "tipos" do Brasil, a arquitetura vernacular, temas de alguns de seus ensaios fotográficos na Módulo.

E ainda, sobre a falta de relações de formação e trajetória, de que adiantava saber que Gautherot havia estado no México, se não se contavam com elementos para classificar tantas fotos desta experiência única de reportagem de juventude, o âmbito etnográfico em que elas se inscreviam, e sua posterior difusão em revistas francesas de destaque nos anos 1938-194034?

Não se reconheciam nem se situavam seus contatos em relação às linguagens da fotografia do entre-guerras (como a Nova Visão e a Nova Objetividade, já mencionadas aqui), os ângulos oblíquos emprestados a René Zuber que esteve também na Alemanha, e os gros plans realistas de detalhes, na linha de um Albert Renger-Patzsch - caso das fotos da flora brasileira que destaquei na exposição e catálogo de 2007 - essas e outras imagens permaneciam desconhecidas e mudas, desligadas de vivências anteriores tão fundamentais. Hoje, devidamente identificadas e contextualizados elas inscrevem o fotógrafo e seus procedimentos em uma história internacional da fotografia ${ }^{35}$.

Como, afinal, se podia estudar Gautherot sem considerar a experiência do deslocamento como hiato, sem redimensionar em suas devidas proporções a mudança para $\circ$ Brasil, e perceber a volta, decênios depois, de linguagens experimentadas por muitos fotógrafos de sua geração, mas que já não eram mais praticadas por eles nos anos 1950-60, como acontece com ele no Brasile Não podíamos nos furtar de dimensionar o salto afirmativo do "exílio" na carreira que se consolida, a relação "exílio e criação" no processo de re-fundação profissional do outro lado do Atlântico, a legitimidade de exercício do métier tecida graças às amizades nos meios institucionais, aos laços com figuras de destaque nacional: Niemeyer, Rodrigo Mello Franco, Edison Carneiro, Burle-Marx... Entre arquivos e coleções diversas, muitas respostas foram dadas e lacunas preenchidas, mas ainda restam questões a partir delas, para melhor iluminar as histórias pessoais que se cruzam em itinerários de elaboração das convenções de representação do país 36 .

Voltando ao estágio das pesquisas e sugestões de caminhos metodológicos a tomar no estudo sobre periódicos: constatei resultados mais ou menos recentes sobre os levantamentos relativos às revistas de urbanismo e de arquitetura dos séculos XIX e XX na França, bem como aos acervos de fotografias, comprovando que a empreitada 
não é impossível ${ }^{37}$ - instrumentos de pesquisa têm se constituído na busca de métodos críticos de análise (e não só relativos à arquitetura). Desses levantamentos apreendemos diretrizes fundamentais (que hoje nos parecem óbvias), integrantes ou complementares de estudos monográficos, sintetizadas nos passos seguintes: - estabelecer um repertório dos títulos, os anos de circulação e as interrupções (a periodização), levantar os temas evocados e as rubricas regulares, as linhas de orientação editorial, a biografia intelectual dos autores e pessoas envolvidas, os temas mais frequentes, as tiragens, as formas de consumo (assinantes, e distribuição), a presença das fotografias, os códigos de representação, seus autores, as repetições de ilustrações de uma revista à outra, as sessões - artigos, resenhas, bibliografias, publicidade, cuja prática nas revistas de arquitetura, a Módulo entre tantas, persiste; enfim, ao historiador que se debruça sobre tais documentos interessa não só o discurso central, mas tudo o que é periférico a ele, do projeto gráfico às fotografias, manipuladas pelo trabalho do diagramador, em particular cortes e recortes.

Ao cotejar as fotografias de Gautherot na Módulo com as das pranchascontato do seu acervo no IMS, encontramos marcas de lápis nestas últimas sugerindo sua participação nos cortes feitos nas fotos publicadas (ver exemplos mais adiante). Ele fotografava com a Rolleiflex, resultando em imagens de formato quadrado - ora, sabe-se que no final dos anos 1950, a maioria dos fotógrafos já havia abandonado essa câmera, pois inapropriada para a reportagem, daí os inúmeros cortes para tornar retangulares as tomadas.

A segunda questão que anunciei, de ordem contextual, confirma historicidades partilhadas de linguagem figurativa em torno das representações do Brasil. Os periódicos profissionais bem como as revistas de fotorreportagem participam ao mesmo tempo da atualidade como vetores de informação e como meio de difusão de convenções visuais. Módulo começa a circular em março de 1955, meses antes da posse de Juscelino Kubitschek em janeiro de 1956, que marca a era de otimismo, de auto-confiança que se instala no país, de um governo que se define por uma política econômica nacional-desenvolvimentista, pela propaganda oficial de realizações de "cinquenta anos em cinco", de um Programa de Metas em torno da energia, transportes, alimentação, indústrias de base e educação, coroado com a meta-síntese que revolucionaria a geopolítica do espaço territorial do país, a construção de Brasília. Em março de 1956, a Módulo n 4 exibe uma entrevista exclusiva com o presidente JK sobre a arquitetura moderna (com várias fotos sem identificação), que explicita a vocação principal da revista - ser a vitrine da construção da nova capital e do espírito entusiasta daqueles anos.

No que tange à política cultural, o conhecimento do país e a construção de sua imagem apoiados num mercado editorial em franca expansão e em institutos e órgãos voltados para as ciências do homem, começara decênios antes, com o nacionalismo da era Vargas (o surgimento das universidades, sabe-se, situa-se também aí) - mas se algumas representações passam por uma estabilização lenta, outras estão destinadas a marcar presença no período, a se tornarem paradigmáticas da afirmação de uma busca de autonomia e "originalidade" culturais do Brasil ${ }^{38}$.
37. Sobre a iconografia de livros e periódicos referentes ao urbanismo, ver Hélène Jannière (2007). Sobre levantamentos de periódicos de arquitetura, embora mais voltados para o século XIX, ver Jean-Michel Leniaud e Béatrice Bouvier (2001).

38. Esse voluntarismo de auto-representação consciente e organizada em várias frentes de construção de imagens emblemáticas, foi objeto de artigos do dossiê "Representações do Brasil: da viagem moderna às coleções fotográficas", que organizei nos Anais do Museu Paulista, em 2005, quando se buscou associar os sistemas iconográficos de Mário de Andrade, Percy Lau, Pierre Monbeig e Marcel Gautherot; ver Heliana Angotti-Salgueiro (2005b). 
39. Cf. palavras de Edison Carneiro quando se referia à pesquisa de folclore, citado por Lygia Segala, p. 3 do original manuscrito consultado antes da publicação (2012).

40. Ver Aujourd'bui. Art et Architecture (1964).
Reportagens fotográficas de Gautherot na Módulo: cultura popular, natureza e modernismo

Passemos aos aspectos precisos do conteúdo da Módulo, especificamente às fotografias de Gautherot, atribuídas ou reconhecíveis como suas: primeiro as dos ensaios específicos, depois as fotos avulsas, e para concluir, as fotografias de Brasília; atente-se que a identificação da autoria é sempre ocasional, tanto em reportagens especiais como em clichês avulsos.

Na Módulo no 1, ele faz seu primeiro ensaio fotográfico, mas sem atribuição de autoria, em artigo autoral de Gastão Cruls, "Bonecas Carajá" - são nove contatos que estão entre os raros de seu acervo tirados no estado de Goiás, na llha de Bananal, em torno de 1953, em que uma índia Carajá modela, pinta e apresenta esculturas de cerâmica conhecidas pelo nome de "licocó" (Figura 12). Algumas estão na coleção do MinC/IPHAN, sob guarda do Arquivo Noronha Santos, classificadas como "Etnografia/Arte indígena". A sequência segue recomendações do registro etnográfico do trabalho de campo, na medida em que constitui "um documento vivo da observação" 39 , descrevendo as etapas da produção do objeto, sem artifícios e encenações. Porém, a autenticidade das cenas e a invisibilidade do fotógrafo, recomendações incontornáveis do gênero, caem por terra na tomada em que o seio da índia é desnecessariamente desnudado: aqui Gautherot deixou-se levar pelos critérios do fotojornalismo.

Neste mesmo número, destaco outro artigo, "As casas sobre palafitas do Amazonas" assinado por Joaquim Cardozo, que mostra quatro clichês sem atribuição, semelhantes aos de contatos do acervo do fotógrafo. Uma casa da mesma série figura anos depois, na capa de uma revista francesa, Aujourd'hui. Art et Architecture, em número especial sobre o Brasi ${ }^{40}$, dividindo o espaço com um exemplar da arquitetura de Brasília, e confirmando a dualidade do "Brasil, terra de contrastes", tão ao gosto dos anos 1950 (Figura 13).

A temática volta na Módulo n 5, de setembro de 1956, no artigo "Arquitetura Popular no Brasil", novamente assinada por Joaquim Cardozo, incluindo além das casas sobre palafitas da Amazônia do artigo anterior, casas de favelas do Rio, e casas de palha no Maranhão (Figura 14). O autor do texto afirma querer ir além do interesse já reconhecido pelos "aspectos antropológicos e etnográficos" dos "barracos, mocambos e palafitas construídas pela população menos favorecida das cidades", e destaca nessa "legítima manifestação da arte popular", valores arquiteturais e construtivos: a tipologia variada das varandas, particularidades no emprego de materiais, e soluções para terrenos abruptos e alagados, "únicos à disposição desta gente sem recursos". Desta feita, seis fotos são atribuídas a Marcel Gautherot e a Franceschi, e uma vista aérea é de Alfredo Mueller.

A arquitetura vernacular, os traços materiais da habitação rural estudados pela geografia cultural francesa nos anos 1930 eram do conhecimento de Gautherot: em 1937, é ele quem fotografa a exposição de Albert Demangeon (curador) e Georges Henri Rivière (museólogo), denominada La maison rurale en France, no 


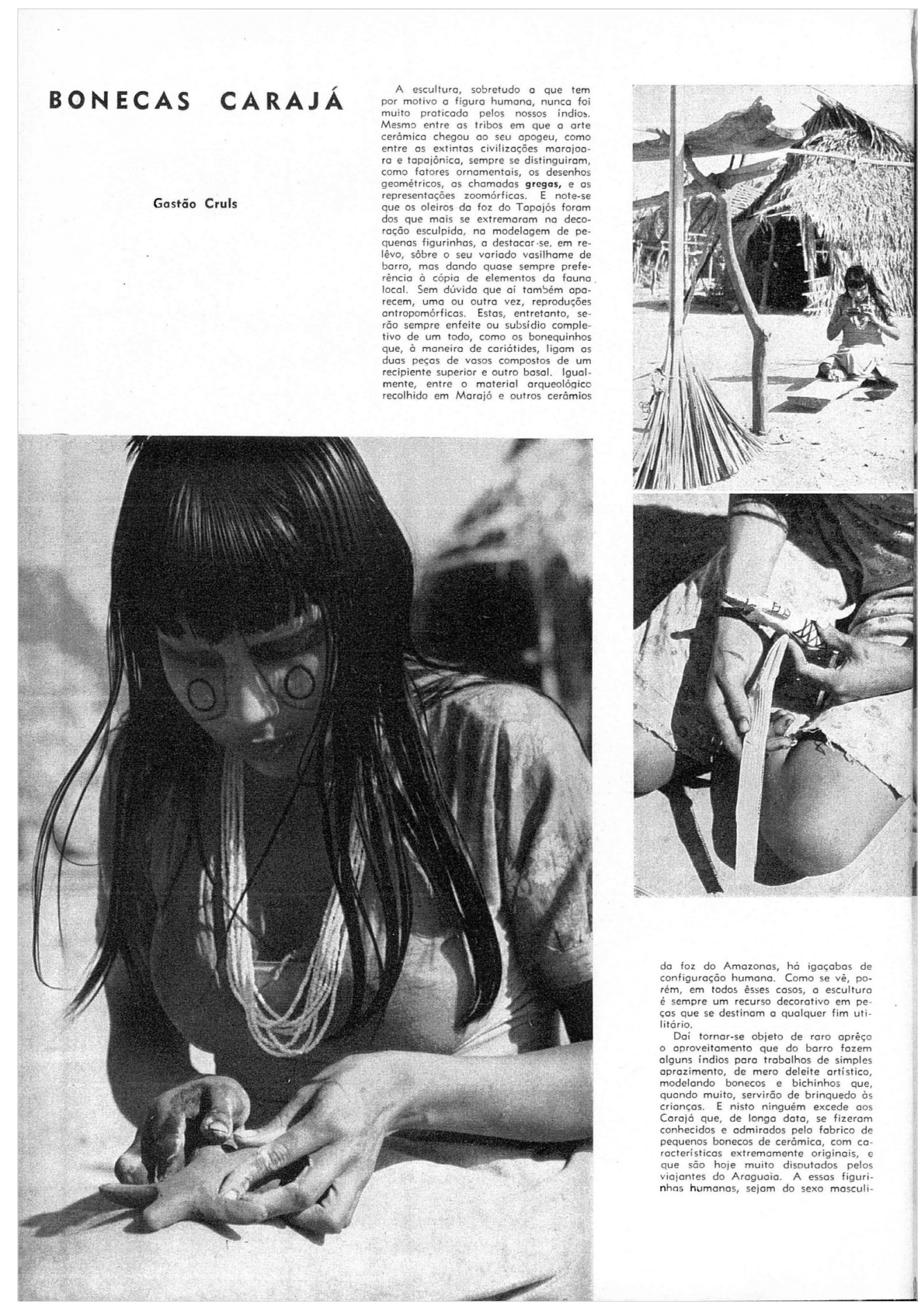

Figura 12 - Página da reportagem "Bonecas Carajá", Módulo n 1, março 1955, com fotografias de Marcel Gautherot sem atribuição de autoria. 
41. A pesquisa de Lygia Segala no Musée des Civilisations de l'Europe et de la Méditerranée (Service Historique Inventaire des Photos, 1936-1942) foi feita no âmbito de um Pós-Doutorado (bolsa da Capes) na França, em 2008.

42. Cf. Lygia Segala (2010). Observamos, porém, a atribuição presente nos anais do Travaux du Ier Congres International de Folklore, publicação do Musée des Arts et Traditions Populaires de 1938; no caso, a primeira prancha, uma vista da exposição de Demangeon, é atribuída a Gautherot.

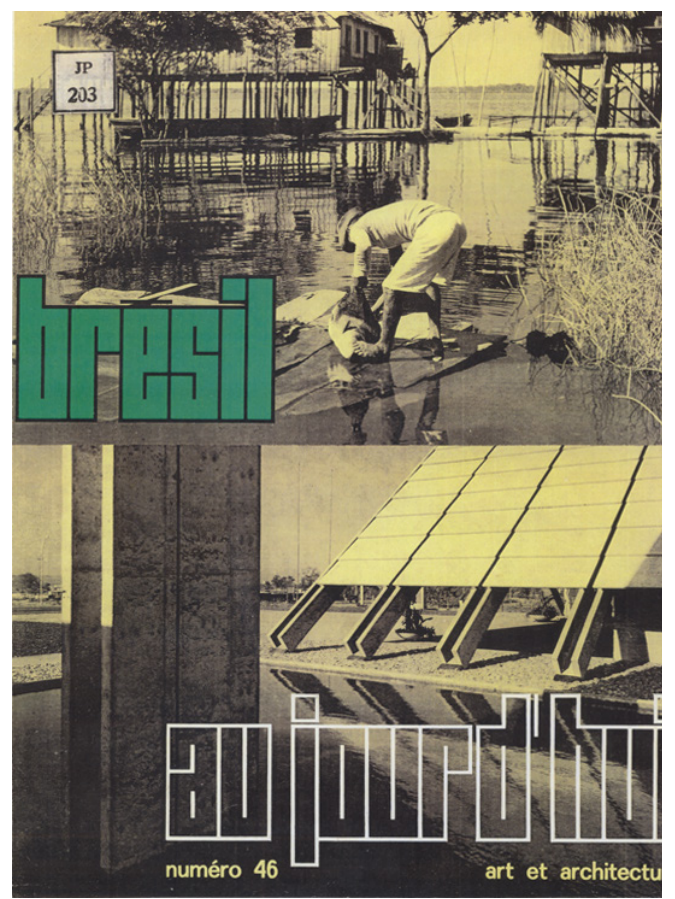

Figura 13 - A arquitetura vernacular e a moderna, em fotos atribuídas a Marcel Gautherot na capa da revista Aujourd'hui. Art et Architecture, n 46, julho de 1964.

âmbito de seu trabalho como arquiteto-decorador das novas montagens de vitrines e painéis do Museu do Homem. Lygia Segala encontrou 41 fotos inéditas de Gautherot no arquivo do antigo Musée des Arts et Traditions Populaires ${ }^{41}$, justamente sobre uma fazenda industrial perto de Paris, "la ferme du Manet" (localizada no departamento de Seine et Oise), e observa que "algumas fotos foram ampliadas na mostra de 1937 e a série serviu de base para a construção de uma maquete, distinguida no catálogo". Reconhecendo seis fotografias de Gautherot no catálogo da exposição de Demangeon, embora sem atribuição de autoria, Segala situa aí o "primeiro exercício sistemático sobre fotografia e arquitetura" do fotógrafo ${ }^{42}$.

A Exposição Internacional de Artes e Técnicas na Vida Moderna, de 1937 em Paris, cujos pavilhões foram retratados para um álbum assinado por Pierre Verger, permitiu que muitos artistas encontrassem trabalho, em plena crise econômica. Anunciava-se a criação do Musée des Arts et Traditions Populaires, no ler Congrès International du Folklore realizado durante a Exposição, que abrigou também a referida mostra de Demangeon fotografada por Gautherot. Sublinham-se entre os ideais da época, o estudo das representações nacionais, a necessidade de documentar o social, de mapear as manifestações regionais em registros comparativos das práticas da cultura material e imaterial pela fotografia, pautada pela autenticidade e a espontaneidade, captando a dinâmica dos movimentos sem pose - este discurso foi internalizado por Gautherot nos meios parisienses do Museu do Homem, e reforçado mais tarde diante das expectativas dos comanditários à frente destas 


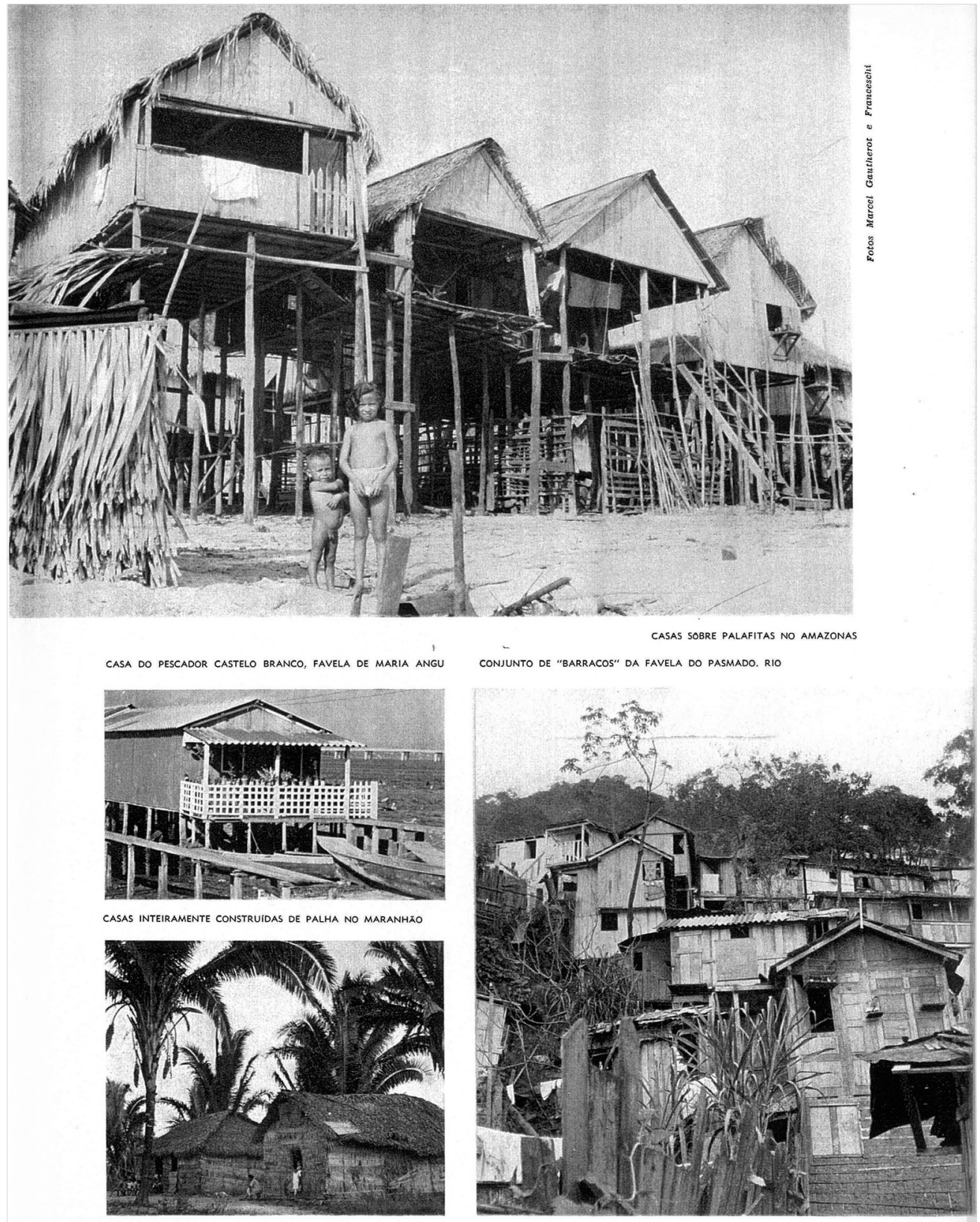

43. Segala vem pesquisando esses temas desde seu trabalho como coordenadora do acervo fotográfico do Instituto Nacional do Folclore (Funarte), no final dos anos 1980. Ver, sobre sua produção, Lygia Segala (1999, 2001, 2007a, 2007b, 2010, 2012). Destaquei a arquitetura popular (casario das cidades coloniais mineiras) como objeto das fotografias de Gautherot paralelamente ao seu trabalho de registro dos monumentos históricos a serviço do SPHAN (igrejas e estatuária do Aleijadinho), divulgadas internacionalmente nos livros de Germain Bazin e em periódicos sobre arquitetura. Não confundir a arquitetura vernacular com a regionalista, abominada pelo fotógrafo no seu discurso de juventude sobre a arquitetura francesa no congresso de Sohlberg, em 1930, seguindo as posturas de Le Corbusier.

Figura 14 - Fotografias com indicação de autoria a Marcel Gautherot, no artigo "Arquitetura Popular no Brasil", na Módulo n 5, ano 2, setembro de 1956.

manifestações no Brasil; de um lado, essas temáticas respondiam às suas próprias convicções de homem de esquerda, marcado pela origem modesta, e, de outro, afiguravam-se como oportunidade de trabalho na convivência com intelectuais identificados com as expressões da cultura nacional, a serem então preservadas pela fotografia ${ }^{43}$. Daí associarmos a esses ideários suas séries documentais sobre o 
44. A frase de Gautherot inscreve-se na crença da fotografia como dispositivo de preservação, e vem da entrevista concedida a Segala no Rio de Janeiro, a 7 de dezembro de 1989, a propósito dos arquivos fotográficos do então Instituto Nacional do Folclore (Funarte). Sobre essa acepção da fotografia documental, ver Olivier Lugon (2007a).

45. Cf. Lygia Segala (2007a, p. 239). artesanato, as feiras, os folguedos populares, os jogos e as festas religiosas e profanas, levantadas em viagens comissionadas a diferentes regiões do Brasil, especialmente no Norte e no Nordeste.

Tema fundamental e incontornável na obra fotográfica de Marcel Gautherot a partir dos anos 1950, as manifestações folclóricas são objeto de seus mais importantes ensaios fotográficos na Módulo, presentes também em outras revistas. Vivia-se desde o final dos anos 1940 um período de plena valorização e de estudos da Campanha Nacional do Folclore; destacam-se nas reportagens, sequências fotográficas narrativas do desenrolar das festas, de detalhes da indumentária, suas máscaras, penas, adereços, bandeiras e bastões, em meio a textos narrativos que associam partituras, cantilenas e versos, assinados geralmente por representantes eminentes do movimento folclórico brasileiro ou dos demais círculos cultos do país. É o caso da Módulo n 2, em que figura o primeiro artigo, "Bumba-meu-boi maranhense", com texto de Joaquim Cardozo e cinco fotos, todas publicadas com cortes em relação aos originais das pranchas-contato de Gautherot, procurando a aproximação do motivo principal, conforme apurei na pesquisa comparativa (Figura 15).

fotógrafo trabalha a serviço dos expoentes do movimento folclórico brasileiro e busca captar a naturalidade e a fugacidade das representações, ciente da eminência do seu fim: "Deixo o povo viver enquanto trabalho (...). O folclore clássico estava desaparecendo, tinha que documentar isso"44. Ao fotografar as festas, Gautherot buscava passar despercebido e a acostumar o outro com sua câmera no registro sequencial da coreografia das lutas e das danças dramáticas - porém, a invisibilidade revela-se muitas vezes difícil nos retratos dos figurantes que não se furtam de fixar a objetiva. Segala observa que "na maior parte dos casos, o sentido da ação reclama uma legenda textual" 45 - carência observada nas reportagens do Bumba-meu-boi - e a falta de relação direta entre texto e imagens, torna-as apenas "ilustrativas" dos artigos.

O tema reaparece na Módulo n 9, de fevereiro de 1958, sobre o "Bumba-meu-boi de Camassari", vilarejo a 40 km de Salvador (Figura 16); trata-se de um longo artigo, de Renato Almeida, seguido da tradução em inglês, com cinco fotos de Gautherot, que ocupam quase a página inteira, desta vez devidamente atribuídas. A inclusão de fragmentos de partituras e a descrição criteriosa evidenciam a importância do autor, etno-musicólogo e estudioso da música popular brasileira ligada ao folclore.

Na Módulo n 10, há um outro artigo sobre manifestações folclóricas, "Dança de Moçambique", com texto de Maria de Lourdes Borges Ribeiro, conhecida folclorista nascida no Vale do Paraíba (Aparecida, SP), ilustrado com quatro pequenas fotos, sem atribuição - note-se que existe uma série sobre a temática no acervo de Marcel Gautherot no IMS.

Em dezembro de 1958, na Módulo n 11, há um artigo sobre $\bigcirc$ "Guerreiro" das Alagoas, com texto do folclorista Theo Brandão, e nove fotos sem identificação, embora sejam todas da autoria de Gautherot, sob layout que também diminui sensivelmente as dimensões das imagens. A multiplicidade dos movimentos, 


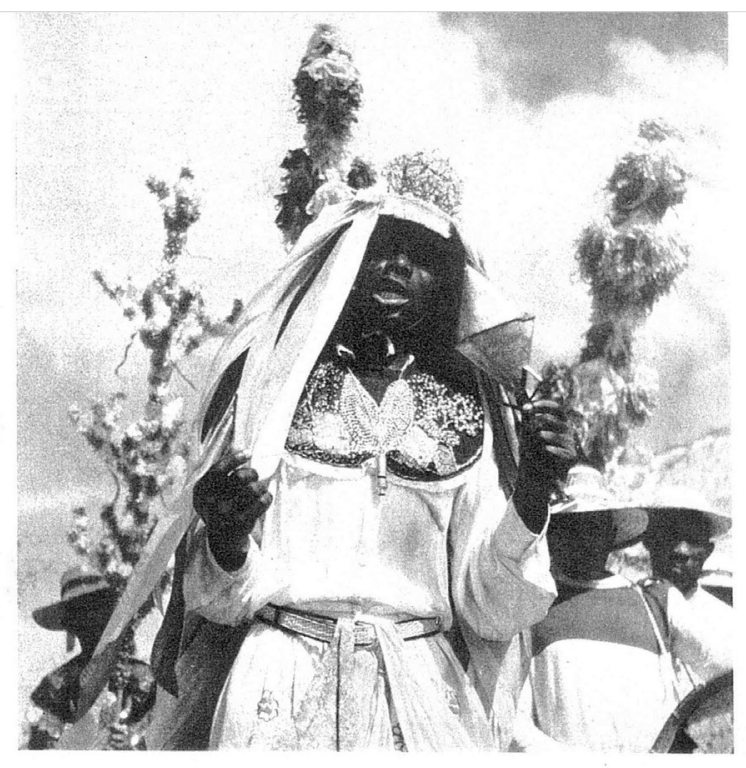

B U M B A - M E U - B O I

MARANHENSE

Joaquim Cardozo

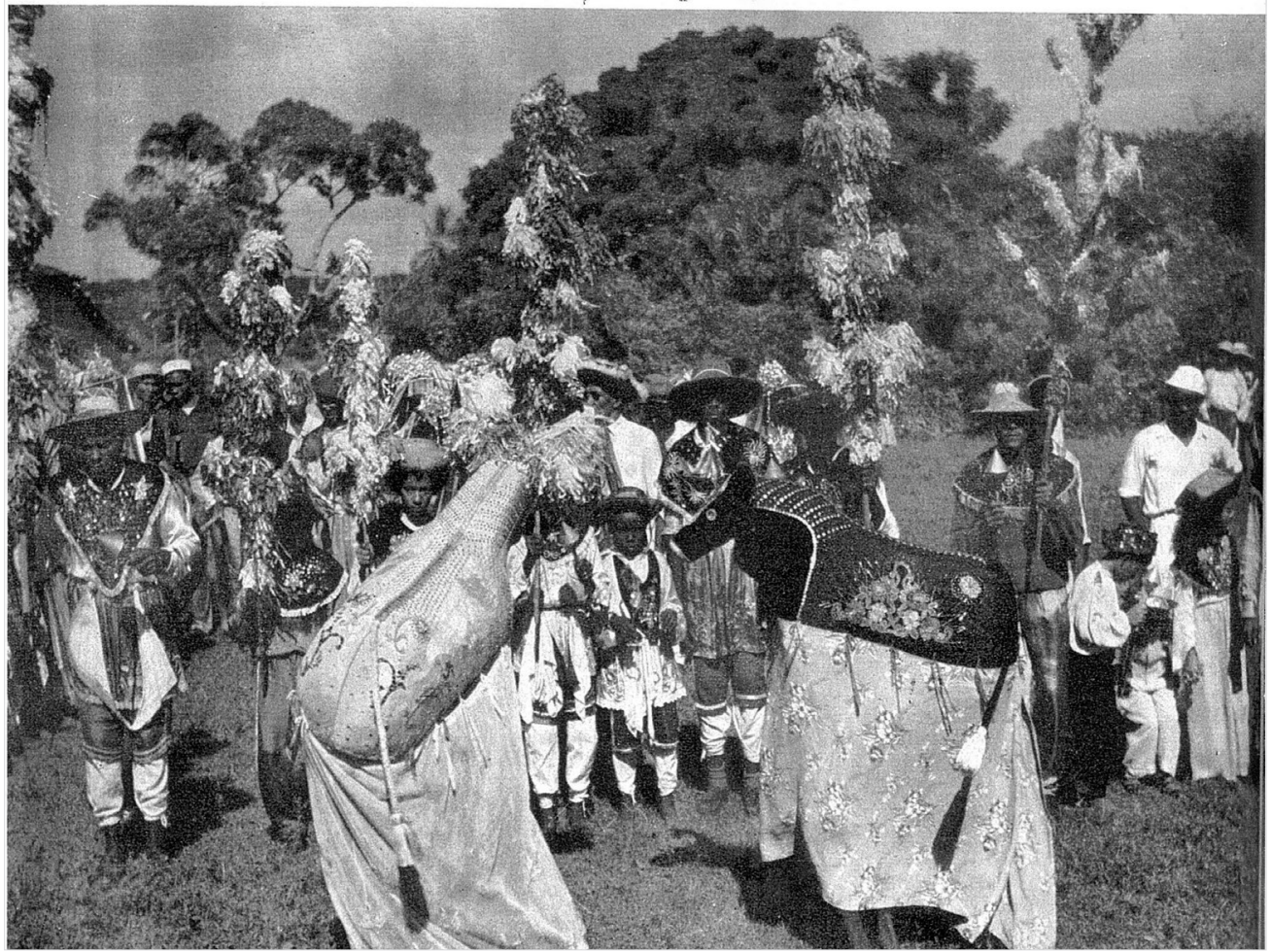

Figura 15 - Fotografias de Marcel Gautherot (sem indicação de autoria) no artigo "Bumba-meu-boi maranhense", Módulo n², agosto de 1955.

os detalhes da indumentária, dos instrumentos bem como os personagens são destacados nas séries e subséries das pranchas-contato do acervo do fotógrafo consultadas para comparação - em relação a elas as imagens selecionadas no 
Ren:ato Almeida

O Bumba-meu-Boi de Camassari

\section{The Drum-Beat-Bull Rite at Camassari}

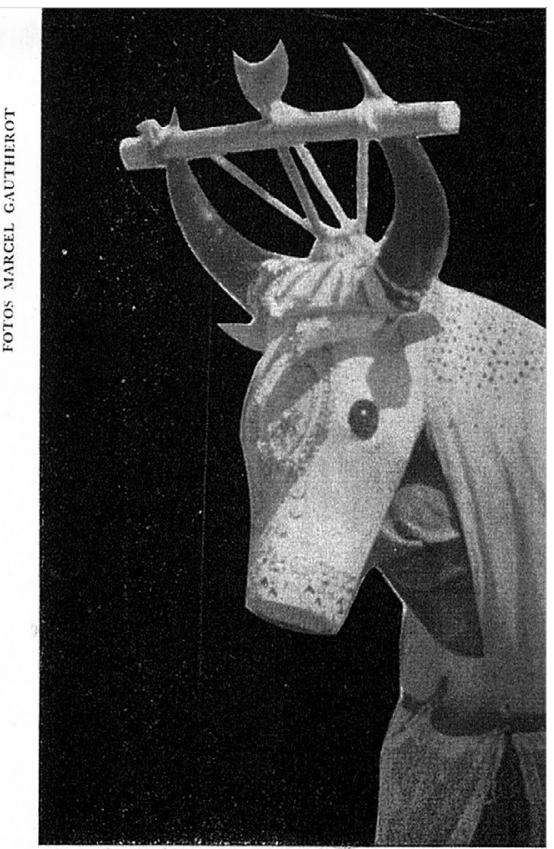

C.umassani é uma pequena localidade a cèrea de quarenta quilometros de Salvador, na Bahia. É procurada para estação de verase, conquanto he falcm ininda os mais remotos cen rápida passagem por ali, em nada superior me parecesse, $\mathrm{E}$ iss ${ }^{\circ}$ corpreensivel, pois se trata de um enorme areal, cuja reverberaça é muito intensa. Uma pecuema peaca quadrangulas, tendo ao meio um jardinzinho cuidado, faz a centro da cidade, donde partem os caminhos que mais tarde serāo as stas ruas. Vida de interior, banzeira, de năofazer-nada .

Quando ringuei a Camassari fui avisado de que, no dia de Reis, houvera nma série de bailados populares, um Bumba, uma Burrinha, etc. Seria talvez possivel fazé-los sair uma ver mais. A ideia naturalmente me alegrou $\mathrm{e}$, à noite, por um caminho muito escuro, ao meio da areia, fui com amigos para ver se seria possivel arranjar as coisas. Depois de andar mais de meia hora, demos na casa da preta Talami (Maria Matrcelina), mae-de-santo da terra, nascida em Jí estava a dormir e custou a despertar. Afinal, veio ì porta, tendo à mio um fifó - pequeno lampião de querosene preso do Prefeito da cidade que também no groças nlava E E Talaini, mulher de uns quarenta anos, nos saudou miito riservarls. enquanto eu espreitava, num canto da sala velado por ruma coberta de chitāo, o peqi, que é o altar onde se celebra o candomblé. Alguém explicou o fim da nossa visita e, tepois de muita conversa e promessiz de agrados (dinheiro e bebida), ficou decidido que, na manhã seguinte, iriam à nossa casa o Boi, a Burrinha, o Urubu e o Bode. Eram nove horas, quando apareceu a faràndula de mulheres, vestidas de branco e com chapéus cada qual da sua côr. Organizavam-se nat forma de buno de keis e traziam como instrumentos quato cisa, cantaram as cantigas traditionais dèsses folguedos. Entrados que foram, entoaram um canto de baile pastoril, com éste estribilho:

\section{$\begin{array}{ll}\text { Bendito louvado seja } & \text { Passeava Säo José } \\ \text { O Menino-Deus nascido. } & \text { Junto cóa Virge Maria. }\end{array}$}

Todos os cantos cram acompanhados por batidas de māo. Findas essas cantorias, que demoraram algum tempo, pois a versalhada cra tros, moi pro foina

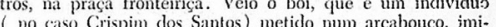

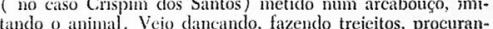
do dar marradas it dircita e à esquerda, investindo daqui,

Figura 16 - Página do artigo "Bumba-meu-boi de Camassari", com fotografias atribuídas a Marcel Gautherot, Módulo no 9, fevereiro de 1958. 
artigo são poucas. A dinâmica do desenrolar dos folguedos perde parcialmente sua força narrativa, ou seja, não se percebe a démarche de captar o tema do geral para o particular, até o retrato dos figurantes, característica a muitas das sequências do fotógrafo, retratos que nesta temática merecem especial registro por suas qualidades plásticas (Figura 17).

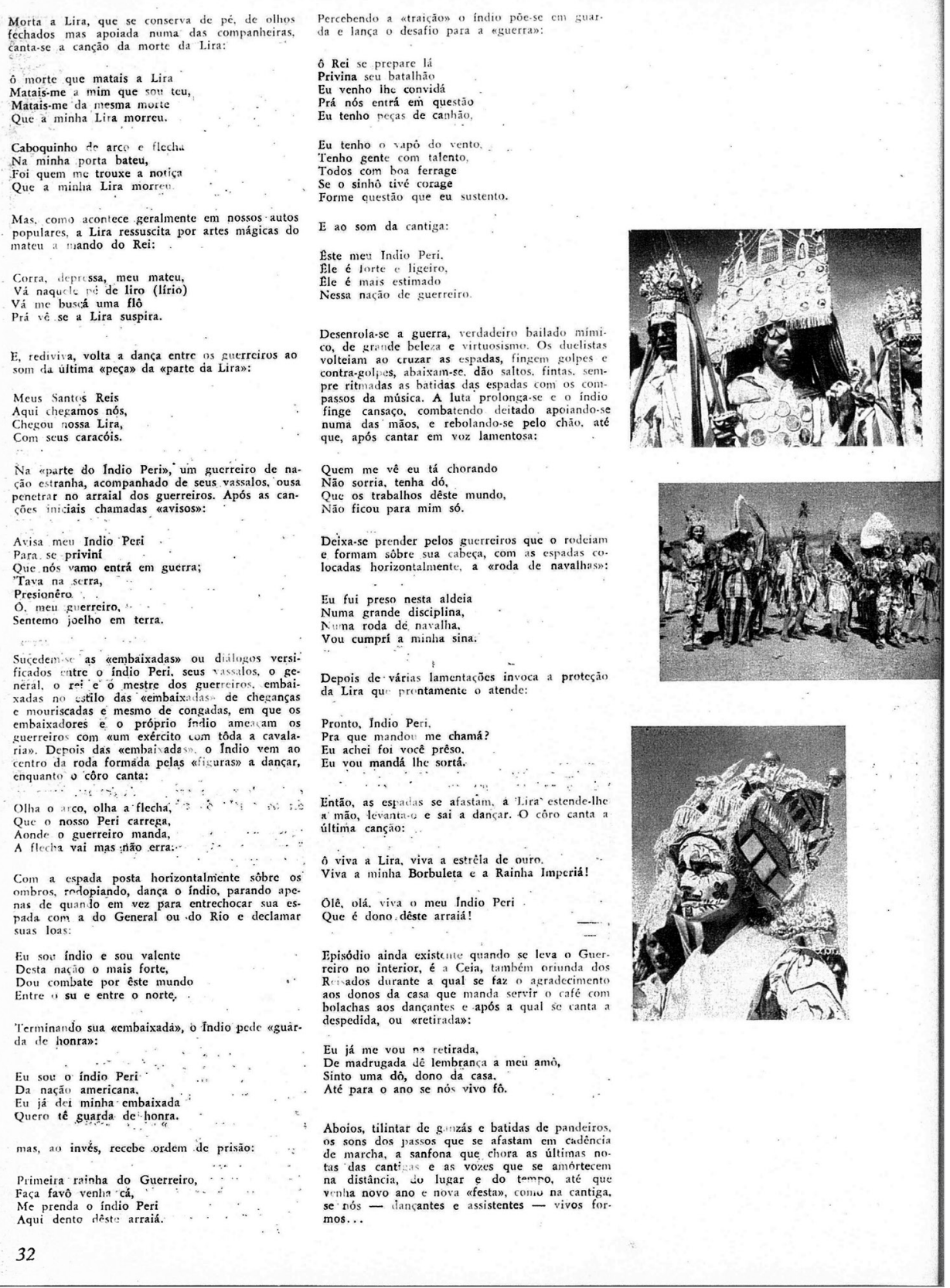

Figura 17 - Página do artigo "O Guerreiro das Alagoas", com fotografias de Marcel Gautherot sem identificação de autoria, Módulo, n 11 , dezembro de 1958. 
Na reportagem sobre a "Capoeira" publicada na Módulo n 4, de março de 1956, com texto do folclorista Édison Carneiro, o nome de Marcel Gautherot é destacado em negrito no resumo traduzido em várias línguas, como "autor das fotografias que dão uma idéia da sucessão dos golpes e contra-golpes característicos deste jogo de vadiagem" (Figura 18). Na comparação das fotografias da Módulo e da Revista Brasileira de Folclore durante a pesquisa em 2005, foi constatada por Lygia Segala e pela autora deste artigo a repetição das

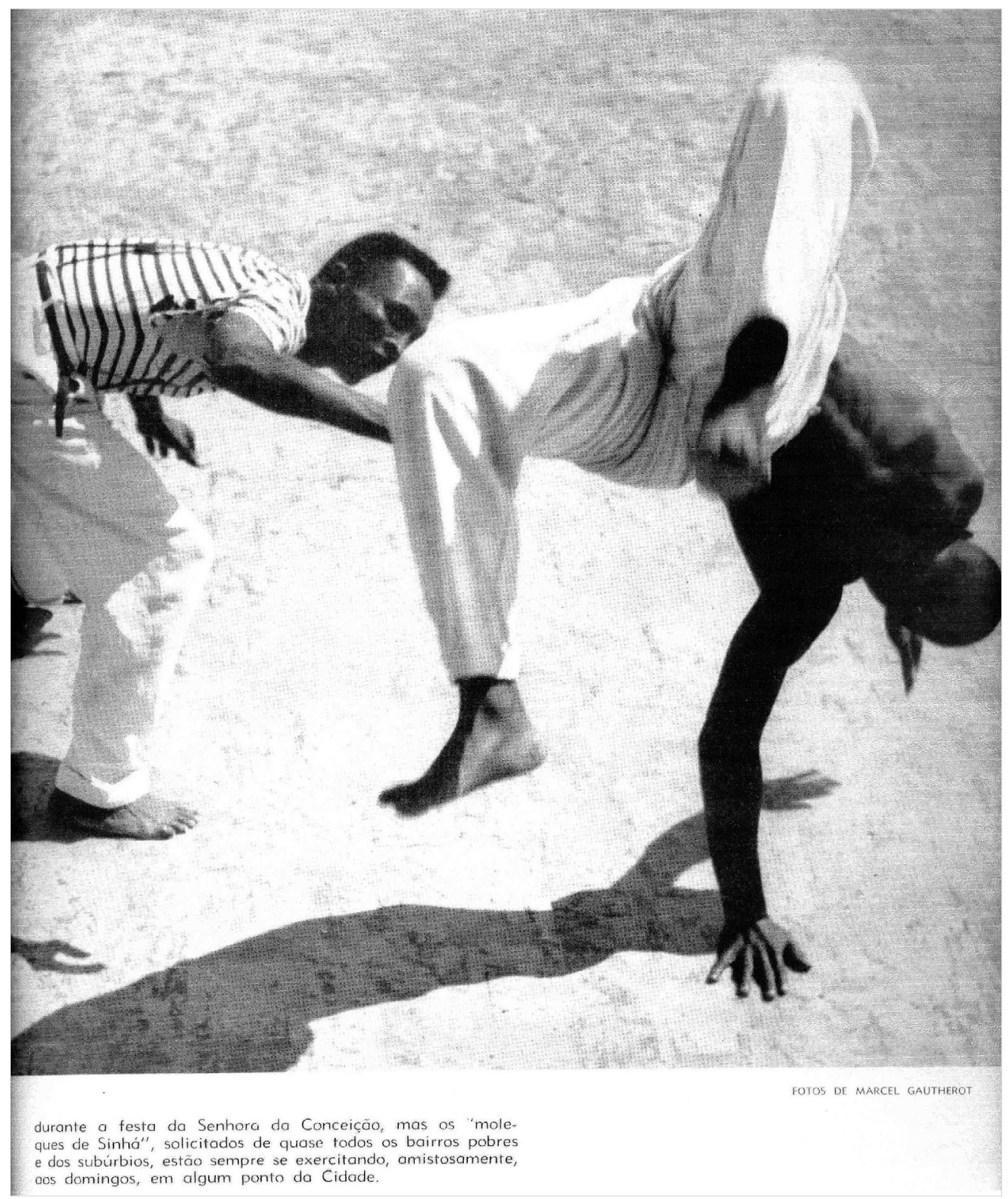

Figura 18 - Página do artigo "Capoeira", com fotografias atribuídas a Marcel Gautherot, Módulo n 4, março 1956. 
mesmas fotos nestas e em outras reportagens, confirmando sua circulação e a validade paradigmática da representação durante anos ${ }^{46}$. As séries de registro da capoeira, esse "patrimônio imaterial do Brasil", são exemplares da fotografia sur le vif, da linguagem cinematográfica que fixa as sequências, a "soma de instantâneos" e a "multiplicidade de pontos de vista para reconstituir um contexto e uma duração", próprios da foto documental47. $\bigcirc$ texto é pequeno e as fotografias predominam, embora passem também por cortes de enquadramento de detalhes e de aproximação dos jogadores ou dos tocadores de berimbau, cortes que interrompem as perspectivas e a profundidade do espaço circundante - areia, mar e céu - com o estreitamento do campo em que a dupla se movimenta; o sol a pino traz sombras no chão, e um efeito de cenário é criado pelo fotógrafo. Lygia Segala observa ainda sobre essas séries que "a idéia da exaustividade recomendada nos manuais etnográficos instiga o refazer de imagens idealmente complementares nas séries - não há datas precisas nas pranchas de contatos do acervo, e a descontinuidade da numeração dos contatos indica que foram feitos em tempos diferentes (Gautherot costumava voltar aos lugares para completar suas séries) buscando contornar as fraturas da narrativa ou do exercício descritivo"48.

As fotografias do artigo "Carrancas de proa do Rio S. Francisco" na Módulo n 3, dezembro 1955, apresentam essas figuras zoo-antropomórficas esculpidas na madeira, à frente de barcos, e exemplificam características básicas do gênero "fotorreportagem": elas primam sobre o texto, ganham independência em relação a ele e reconhecimento de sua plasticidade como forma de arte, explodindo em proporções, justaposições e recortes arbitrários, que escapam das tomadas originais do fotógrafo (Figura 19). Lê-se no início do texto que estamos diante de "uma série de fotografias expressivas feitas por Marcel Gautherot" - a série é longa para os padrões das demais reportagens, ocupa 10 páginas, e apresenta um layout inovador (caderno menor sobreposto, com close de quatro carrancas diferentes, cujas fotos "sangram" a página). A temática é apresentada como "uma das modalidades da arte popular mais interessantes e genuínas do Brasil". $\bigcirc$ texto de um colaborador do DPHAN, Hermann Kruse, remonta aos anos 1940, e sua presença na Módulo, anos depois, sinaliza as relações estreitas entre os intelectuais, artistas, arquitetos modernistas e responsáveis pelo patrimônio. As fotos de Gautherot constituem a mais completa coleção sobre esta arte popular que então desaparecia, visto que documentou cerca de trinta barcas com as figuras que representavam personagens mitológicos do rio. Em 1947, ele já havia publicado uma reportagem fotográfica sobre as carrancas na revista $\bigcirc$ Cruzeiro (Figura 20); em 1950 na primeira edição francesa do livro Brésil, editado por Paul Hartmann em Paris, figuram três fotos, e em 1957 a Revista Shell também inclui fotos de suas séries. Em 1964, elas são numerosas em Aujourd'hui, Art et Architecture (n 46), número que é, aliás, uma síntese dos temas fotografados por Gautherot, também presentes na Módulo, comprovando a circulação das imagens em diferentes periódicos, e a longa duração da recepção das mesmas representações do Brasil.
46. Lygia Segala (2012) observa "como exemplo dessa circulação [que] uma das fotos de Gautherot, (010BACE01665), publicada na revista Módulo é a mesma que aparece na Revista Brasileira de Folclore, n. 4, jan./abr. 1963, com outros recortes de edição. Ela integra a caixa de fotografias encomendadas ao fotógrafo, em 1973, pelo Ministério das Relações Exteriores do Brasil, para distribuição nas principais embaixadas brasileiras. É mostrada ainda, em Paris, na exposição Dances et théâtres populaires $d u$ Brésil que inaugurou, na Sala Sarah Bernhard, o Festival International de Théâtre de 1957. São ainda de Gautherot as fotos que ilustram o texto do surrealista Benjamin Péret, militante comunista, amigo de André Breton." Cf. p. 17 do manuscrito gentilmente cedido para este trabalho.

47. Cf. Olivier Lugon (2001, p. 248), citadas por Lygia Segala (2012).

48. Cf. Lygia Segala (2012), p. 10 do manuscrito. 


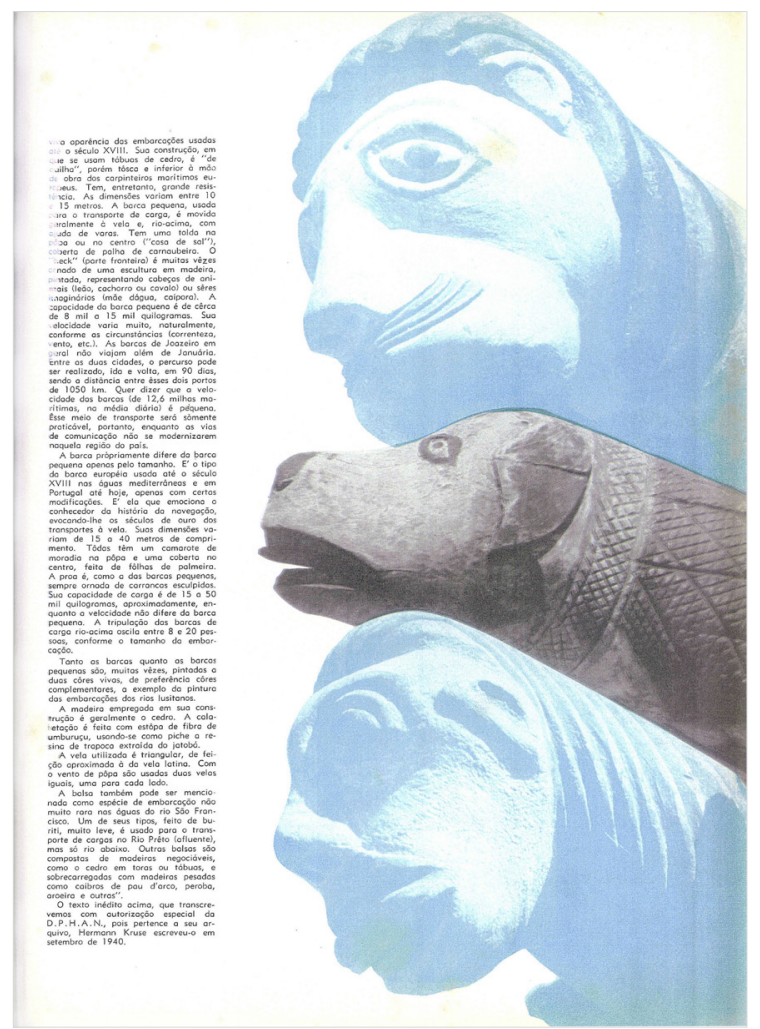

Figura 19 - Página do artigo "Carrancas de proa do Rio S. Francisco", com montagem de fotografias recortadas de Marcel Gautherot, Módulo n 3, dezembro de 1955.

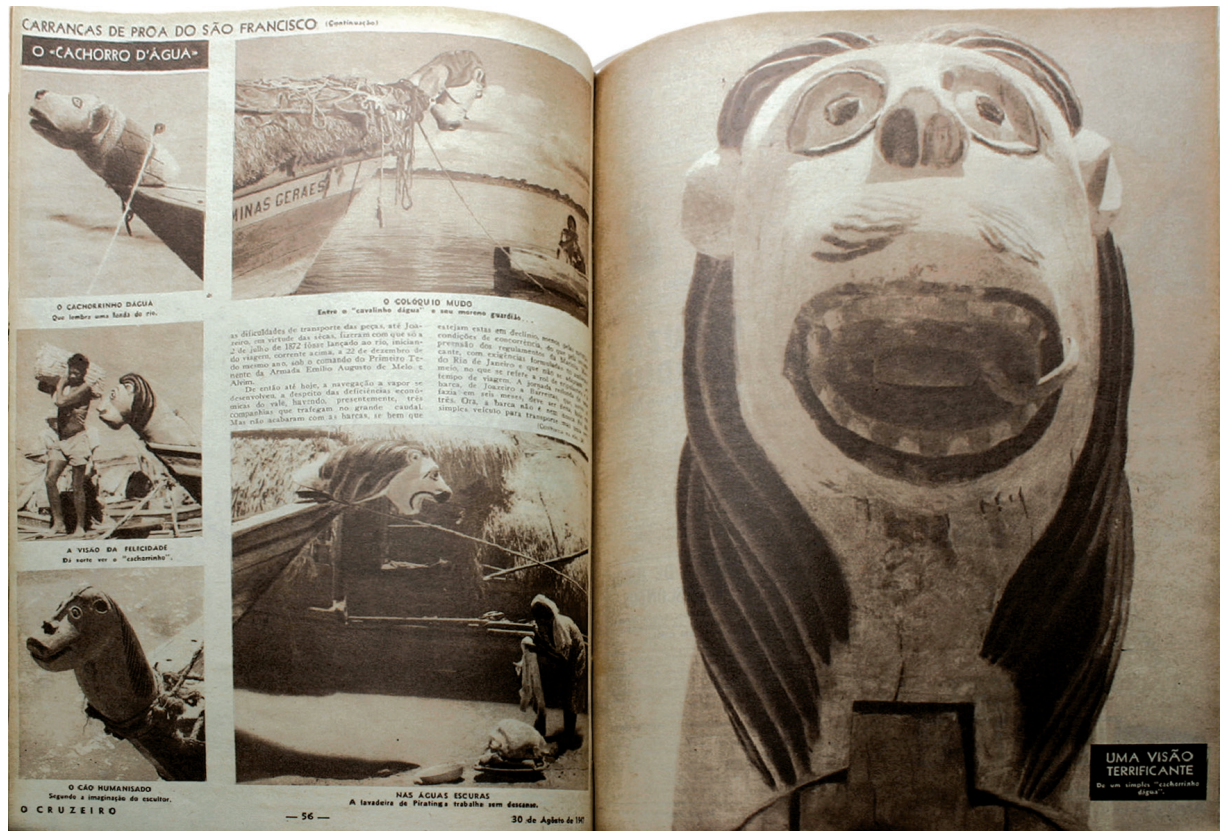

Figura 20 - Páginas da revista O Cruzeiro, reportagem sobre as carrancas do Rio São Francisco, com fotos de Marcel Gautherot, Rio de Janeiro, 30 de agosto de 1947. 
A pesquisa sobre as fotos das carrancas nos arquivos do SPHAN realizada por Lygia Segala ${ }^{49}$ evidenciou que o carimbo do fotógrafo no verso ainda trazia seu endereço parisiense, pesquisa que possibilitou a indicação de dados valiosos como datas e roteiros de viagem - em 1943, Gautherot já viajava pelo rio, passando por "Lapa, Barra, Casa Nova, Remanso, Petrolina, Juazeiro". Sabese que ele voltou à região em 1946, em companhia de Verger, pois há registros conhecidos em que os dois fazem retratos um do outro fotografando carrancas, em Bom Jesus da Lapa.

Esse número 3 da Módulo continua exemplar do conteúdo variado presente no periódico, pois os artigos versam sobre uma fazenda do ciclo do café, por Rodrigo Mello Franco de Andrade; o mosaico moderno de Paulo Werneck; e - plano urbanístico de Moscou. Traz também dois artigos específicos sobre arquitetura: um sobre novos projetos executados, e o outro, "Problemas atuais da arquitetura brasileira", assinado por Oscar Niemeyer, precedido da foto avulsa p/b da igreja da Pampulha, de 1942, que traz a autoria de Marcel Gautherot, sendo essa foto retomada em publicações internacionais, hoje livros clássicos do modernismo, como Latin American Architecture since 1945, de Henri-Russel Hitchcock (Figura 21).

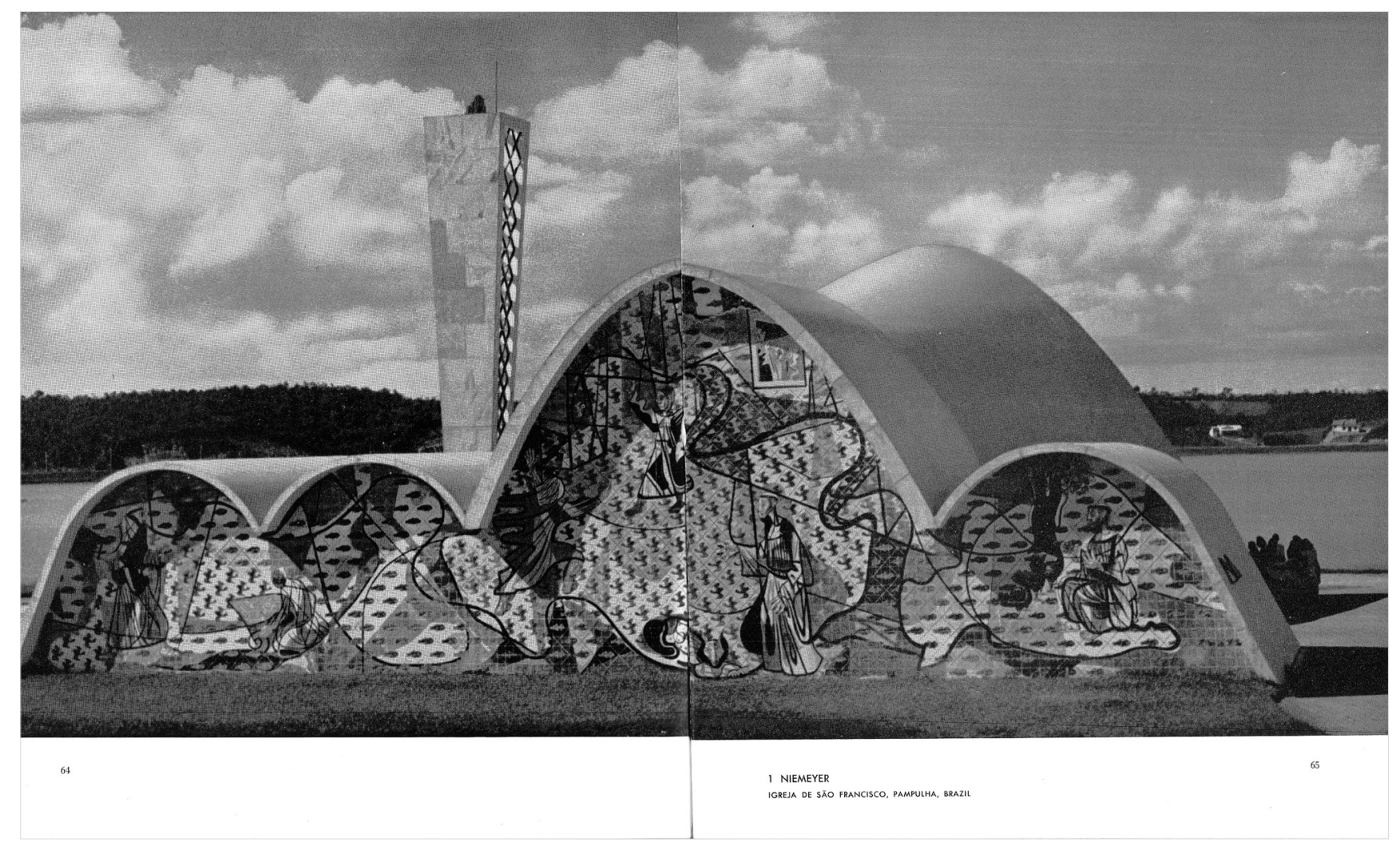

Figura 21 - Página dupla do livro de Henry-Russel Hitchcock, Latin America Architecture, since 1945, representando a lgreja de São Francisco (Pampulha, Belo Horizonte), obra de Oscar Niemeyer fotografada por Marcel Gautherot, em 1942. 
50. A expressão é de Oscar Niemeyer (1955b, p. 21) ao tratar dos problemas da arquitetura brasileira, na rubrica Urbanismo; as demais expressões do parágrafo seguinte são da série de artigos "Em defesa da cidade", Módulo $\mathrm{n}^{\circ} 1$ e Módulo $\mathrm{n}^{\circ} 3$, sem assinatura, que exibe as fotos de Gautherot.

51. Observação de Lygia Segala, p. 2 do manuscrito gentilmente cedido para consulta, antes da publicação (2010). Sobre a questão, ver também meu capítulo "Paisagem, natureza, flora", em Heliana Angotti-Salgueiro (2007b, p 189-205).
Esta igreja já era então, após o edifício do MES, outro ícone da arquitetura brasileira, graças às suas peculiaridades: o volume escultural das formas curvas, o uso do azulejo como revestimento externo por Portinari, bem como seus murais internos pintados, sintetizam a chamada "integração das artes" do modernismo, tendo sido a capela objeto de fotografia colorida no número especial "Brésil", em L'Architecture d'Aujourd'hui, de 1947 (a que já fiz referência). O conjunto da Pampulha pode ser considerado um marco fundador da associação do arquiteto com o fotógrafo, que continuará a ser convocado pelo primeiro, mais de dez anos depois, para documentar a construção das obras de Brasília, como veremos mais adiante.

Seguem-se, ainda nesse no 3 da Módulo, um longo artigo de Lúcio Cosła sobre a evolução do mobiliário luso-brasileiro acompanhada de croquis, e uma apresentação de Cândido Portinari dos seus "gigantescos painéis para o edifício da ONU". Tal elenco de temas demonstra a preocupação da revista em exibir o nacionalismo na arte, a busca do que é "brasileiro", o registro das representações e práticas coletivas, urbanas e rurais, materiais e imateriais, o compromisso com a atualidade das artes plásticas e o destaque de seus portavozes, além dos caminhos da arquitetura e descaminhos do urbanismo.

Neste particular, a série do artigo "Em defesa da cidade", publicada nos primeiros números indica que os redatores querem denunciar a direção que vem tomando a política urbana - o "Report on Brazil", da Architectural Record (1950), já havia destacado a negligência em relação à habitação e a falta de planejamento das cidades no país. O terceiro artigo da série, também na Módulo n० 3, apresenta-se com três fotos avulsas atribuídas a Gautherot, que mostram o começo da transformação do skyline do Rio de Janeiro, enfocando as primeiras estruturas de concreto que sobem na enseada de Botafogo, fruto "do estado lastimável de nossas cidades, entregues ao descaso dos poderes públicos e à ação nociva do comércio imobiliário" ${ }^{50}$. Desde o primeiro artigo, na Módulo n 1 , reivindica-se um "plano-diretor que fosse ao mesmo tempo um plano protetor", "baseado no homem em movimento e na maravilhosa paisagem", a criação de uma comissão para "preservar o panorama", o "perfil dos morros", a "moldura" de suas montanhas, a "integridade dos morros que constituem essa moldura", "procurar defender o que ainda nos resta, o que ainda não conseguiram destruir". As soluções sugeridas deveriam corresponder à paisagem da cidade, pensadas "como Le Corbusier o fez em 1937" (sic). (Figura 22). Esse gênero de fotografia sobre os problemas urbanos contemporâneos não é comum no acervo de Gautherot, mas não poderia faltar na Módulo, pois era um tema dos congressos de arquitetura, herdado das vanguardas européias.

Outra temática bem representada fotograficamente por Gautherot na revista refere-se a aspectos da natureza brasileira: "das suas primeiras aproximações com o país, viajando pela Amazônia, o que o seduz - revela - é a largueza das matas intrincadas e das águas, o excesso da luz" ${ }^{\prime \prime}$. Já no México, em 1936, ele havia enquadrado personagens e cenas com plantas nativas, o agave gigantesco 


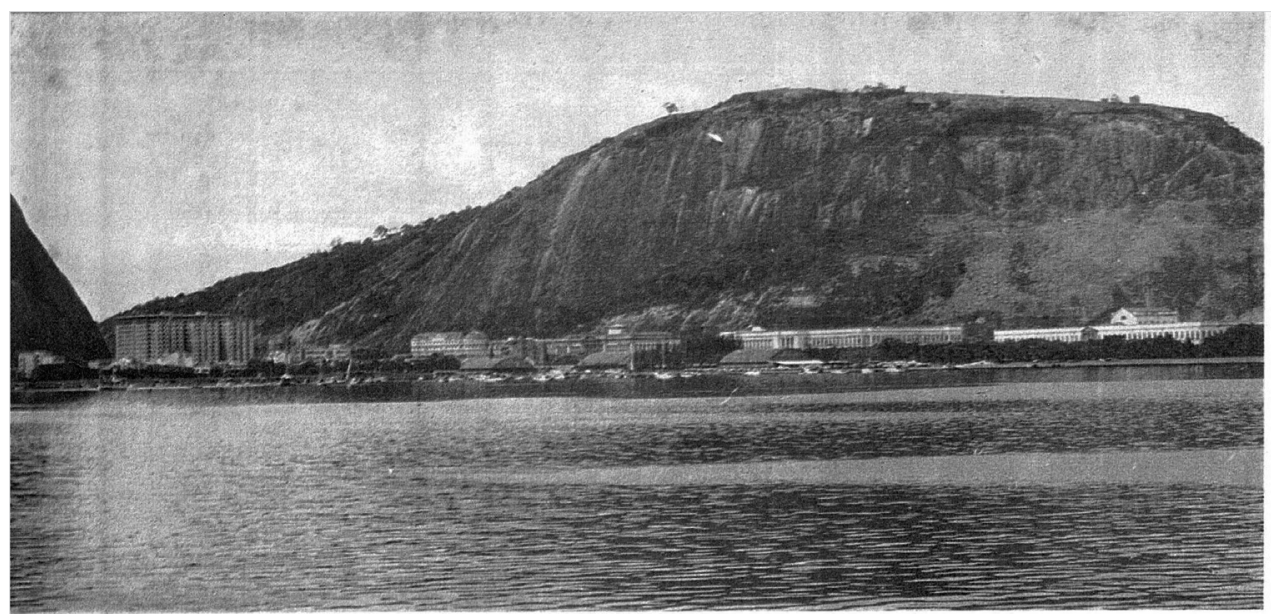

\section{EM DEFESA DA CIDADE}

1 - Da paisagem característica do Rio de Janeiro um dos últimos trechos que ainda não tinham sido sacrificados era o perfil dos morros cobertos de vegetação ao fundo da enseada de Botafogo, entre os quais se destacava o Corcovado, com o monumento ao Cristo Redentor. Por tolerância imprudente da administração municipal, foi permitida há anos a construção de um primeiro e volupermitida há anos a construçáo de um primeiro e volumoso edificio de apartant de Olinda, que se manteve, felizmente, por longo tempo, isolado no meio do casario da praia, cuja altura não ul- go de tôda a extensão da formosa curva litorânea de Botafogo dispararam a subir novas estruturas de concreto armado de tais proporções que, já agora, passaram a impedir a vista do monumento do Corcovado ao transeunte da praia, durante grande parte do percurso. Dentro em muito breve um paredão imenso e ininterrupto ocultará por completo a lindíssima moldura antiga de Botafogo. Ao mesmo tempo, cometiom-se atentados os mais aflitivos contra a própría integridade dos morros que constituem essa moldura mutilando-os e desfigurando-os horrivelmente, por meio de cortes e desaterros visando novos arruamentos a a outros enormes edifícios sôbre os elevações.

O que foi feito da praia de Botafogo e da sua paisogem tradicional é deprimente para a cidade, para os pogern tradiclicos que consentiram na barbaridade $e$ até mesmo para a população que deixou consumá-la sem mesmo

A estátua colossal ao Cristo Redentor foi levantada no cume do Corcovado com o pensamento de impó-la à

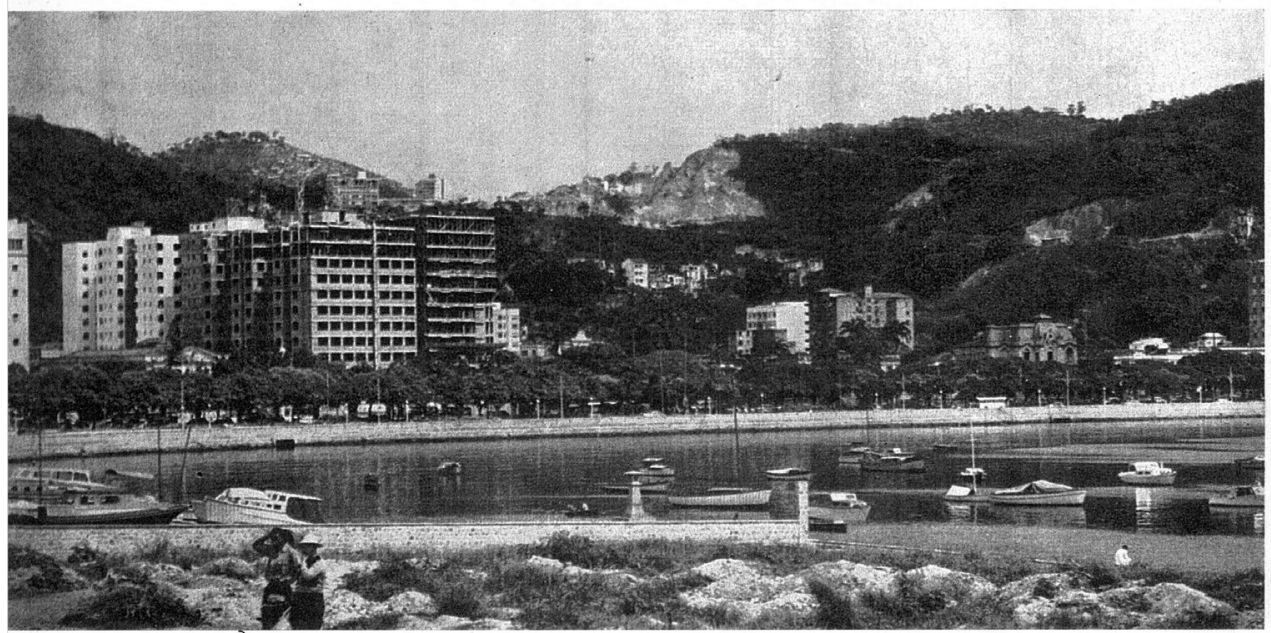

Figura 22 - Página com fotografias atribuídas a Marcel Gautherot, no artigo "Em defesa da cidade", sobre a verticalização do Rio de Janeiro. Módulo n 3, dezembro de 1955 
no primeiro plano, como fará aqui com os galhos enegrecidos dos igapós. Na Módulo n 7, de fevereiro de 1957, o artigo "A natureza faz escultura", destaca sua autoria nas sete fotos (das quais três ocupam páginas inteiras), conferindo-lhe foros de ensaísta visual (Figura 23). A representação de galhos, troncos secos e raízes tentaculares na história da fotografia, de Adget a Walker Evans, passando por conterrâneos de Gautherot e de Verger como René Zuber, inscreve-se no gênero documentário que, no caso, associa-se ao encantamento do fotógrafo pela natureza brasileira e explica essas imagens para além da pura opção estética. Gautherot fez várias fotografias de mangues, como as que constam em seu photo-book - "Da Amazônia ao Trópico de Capricórnio", que não foi além de uma classificação por temas e fotos em diálogo, coladas em folhas de cartolina; nele, uma das aberturas se intitulava "Personagens da Floresta", com fotos parecidas a outras que haviam marcado os anos 1930 (vividos por ele em Paris), entre as quais a série dos igapós, de 1956, de que uma delas é divulgada em página inteira nesse artigo da Módulo.

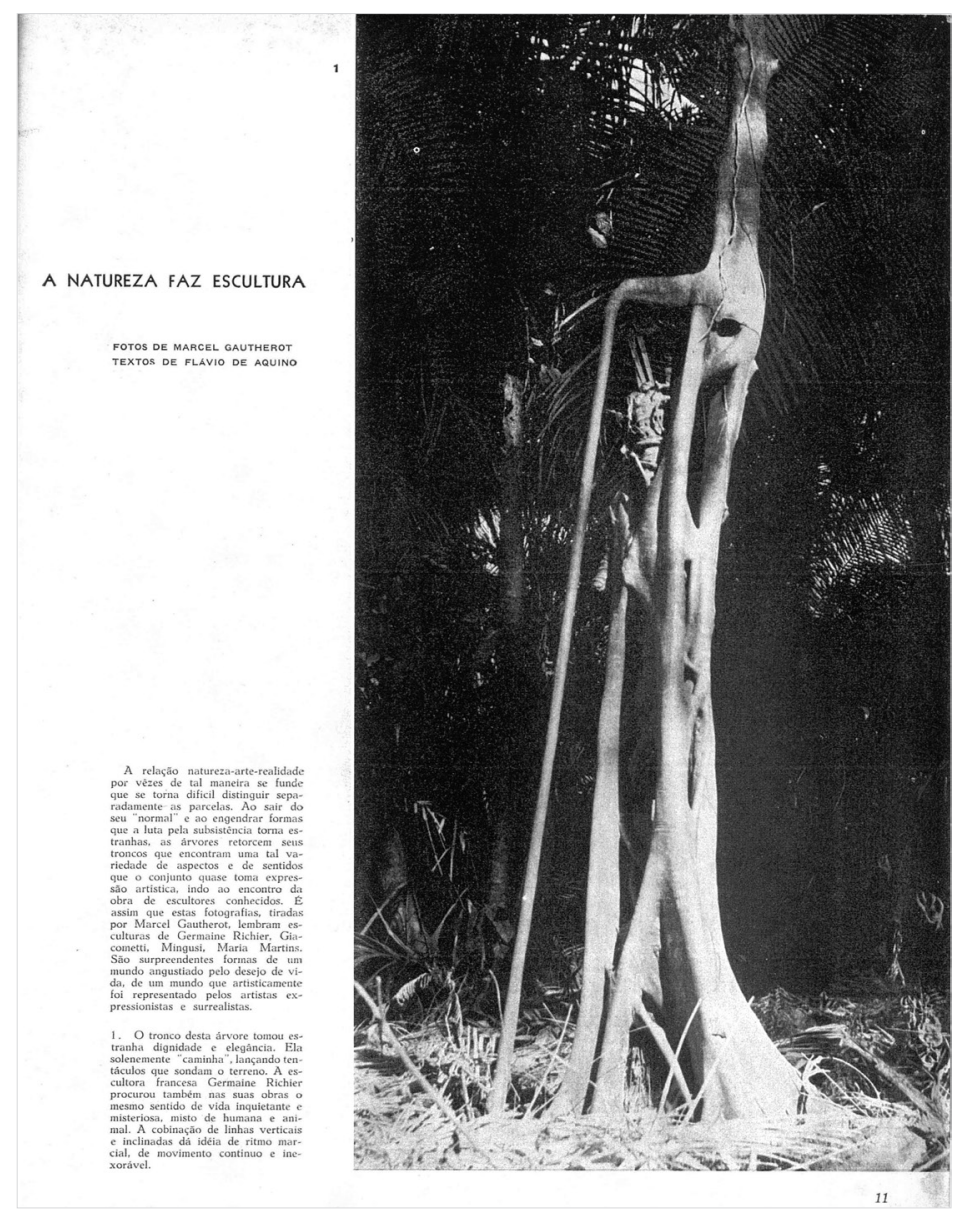

Figura 23 - Página do artigo "A natureza faz escultura" com fotografias atribuídas a Marcel Gautherot, Módulo n 7, fevereiro de 1957. 
As fotos de Gautherot são acompanhadas de texto de Flávio de Aquino (arquiteto e crítico de arte, autor de vários artigos em outros números da revista) que associa "natureza-arte-realidade", atribuindo "personalidade" e expressão surreal e estética aos troncos que assumem "formas estranhas na luta pela sobrevivência", e os compara ora a "animais feridos", ora a esculturas abstratas de artistas conhecidos (Germaine Richier, Giacometti, Mingusi e Maria Martins). Na legenda de uma das imagens atribui-se "impulso vital" a um tronco: "A figura fantasmagórica que esboça um largo gesto para o além, tem função de monumento escultórico na desolada paisagem; grudada no chão por pés que parecem garras, e o corpo inclinado como que indicando um rumo longínquo aos homens que caminham no fundo". Esqueçamos a retórica dramática do texto - a imagem documenta os romeiros de Bom Jesus da Lapa, e a data fornecida pelo IMS é pouco exata, 1940-45.

Nas representações dos aspectos paisagísticos da Amazônia e do sertão brasileiro, presentes no acervo de Gautherot, não raro os homens eram incluídos na cena pelo fotógrafo, numa espécie de "humanismo documentário", comum aos fotógrafos dos anos 1950. O gros plan sobre troncos tentaculares, e a visão destes na paisagem desolada das séries de contatos da llha Mexiana, à rede caótica de galhos densos da floresta inundada, demonstram, afinal, o envolvimento corporal do fotógrafo com seu objeto, especialmente no último exemplo, quando ele entra na água e se coloca em posição que the permite superpor os planos habilmente: no primeiro plano as sombras mais escuras dos galhos assumindo efeito de enquadramento, no fundo da foto as ramagens mais claras e iluminadas, e seus reflexos na água. $\bigcirc$ tema da flora brasileira, enfocado em várias séries do seu acervo, volta em 1964, entre as reportagens do número especial de Aujourd'hui. Art et Architecture, nas aproximações do "realismo" das coisas (follha de carnaúba, tronco de paineira), na linha da Nova Objetividade do clássico Die Welt ist Schön, de Albert Renger-Patsch, de 1928.

Artistas brasileiros também são objeto de vários artigos desde os primeiros números da Módulo52 - a Gautherot são atribuídas nove fotos das esculturas de Alfredo Ceschiatti, em exposição nos jardins da Casa das Canoas, residência de Niemeyer ${ }^{53}$, em artigo sobre o aniversário da revista, na Módulo n 5, de setembro de 1956. Ao comparar as fotografias publicadas com a série dos contatos originais, observei raras indicações escritas a lápis sobre os contatos assinalando enquadramentos e cortes radicais, para focar o motivo central da escultura, ou suas partes (rosto, torso), como nos "Acrobatas": usar o mesmo corte; esta foto e a das "Três graças" aparecem com destaque sangrando a página da revista (Figuras 24 e 25).

A imagem está a serviço do layout, Gautherot se submete à encomenda e não parece se rebelar contra as diretivas editorias, não se alinhando a fotógrafos de sua geração neste particular (Cartier-Bresson entre eles), que se pronunciavam pela integridade da foto proibindo cortes e enquadramentos arbitrários. A série sobre as esculturas de Ceschiatti inclui fotografias de formato 6x9 e as tradicionais $6 \times 6$, que
52. Entre esses artistas, sem que as fotos sejam atribuídas em particular, estão: Maria Martins, José Pancetti, Volpi, Di Cavalcanti, Portinari, Amílcar de Castro, Lygia Clark, Goeldi, Guignard, e outros. Porém, esporadicamente nota-se uma atribuição avulsa a Gautherot em relação à cabeça esculpida que figura em página dupla sem texto sobre o "Monumento Nacional aos Mortos da Segunda Guerra Mundial", na Módulo $\mathrm{n}^{\circ} 6$, de dezembro de 1956.

53. Sobre esta casa, ver Heliana Angotti-Salgueiro (2007a). 


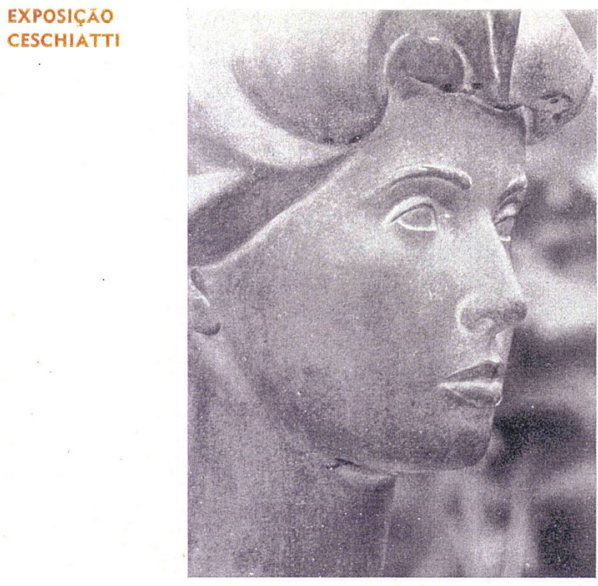

LILIANE Proprietaria: Sra. Ronaldo M. Pinto

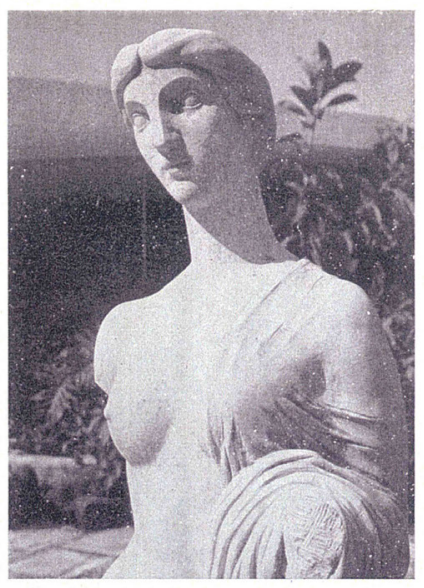

TORSO DE MULHER (DETALHE) Proprietário: Oscar Niemeyer

VISTA PARCIAL DA EXPOSICÃO

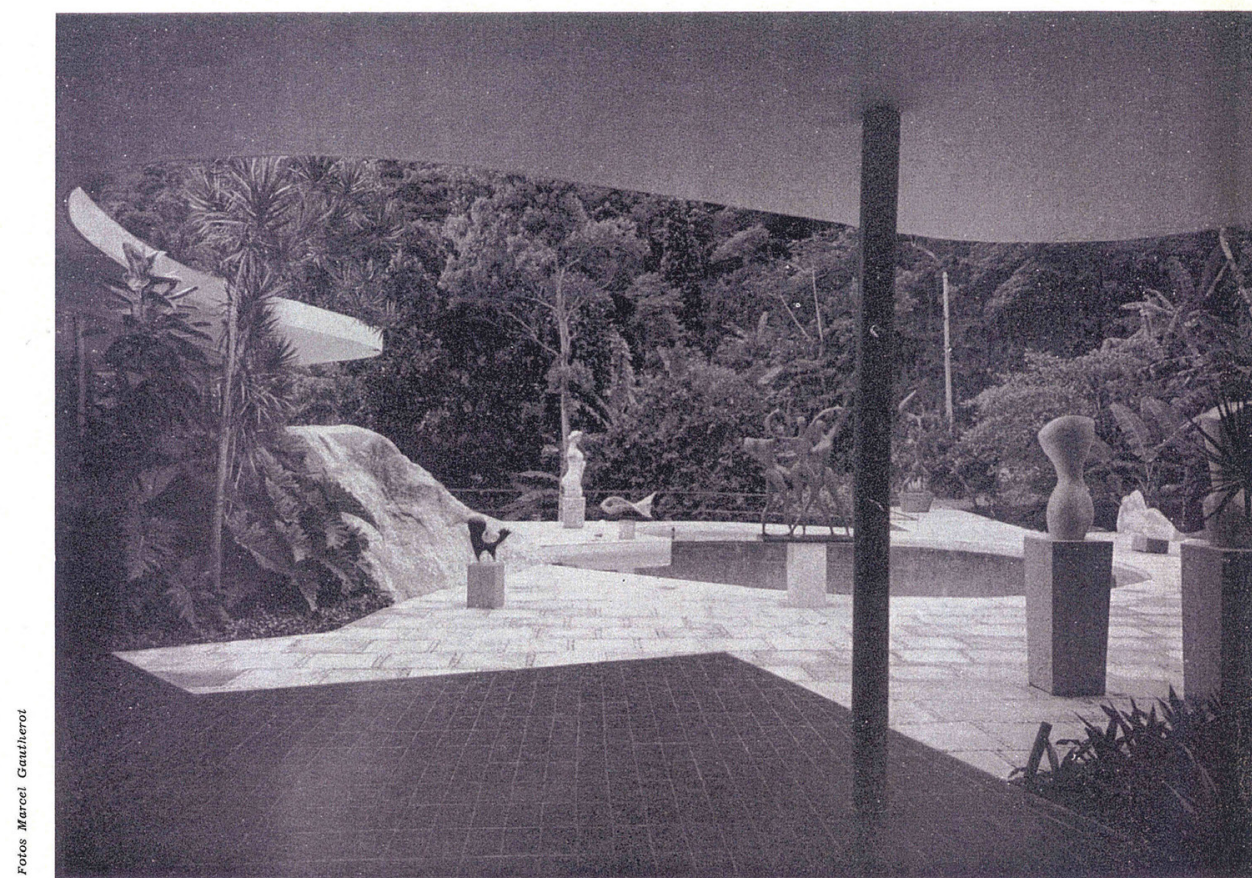

13

Figura 24 - Esculturas de A. Ceschiatti, na Casa das Canoas, em fotos com indicação de autoria a Marcel Gautherot, Módulo n 5, setembro de 1956.

predominam no acervo dos contatos de Gautherot; na revista há também duas vistas gerais da exposição em volta da piscina em que a casa aparece parcialmente.

modernismo, sabe-se, associa a arquitetura às outras artes - é a propalada "integração das artes" presente na Módulo - o próprio subtítulo indica: 


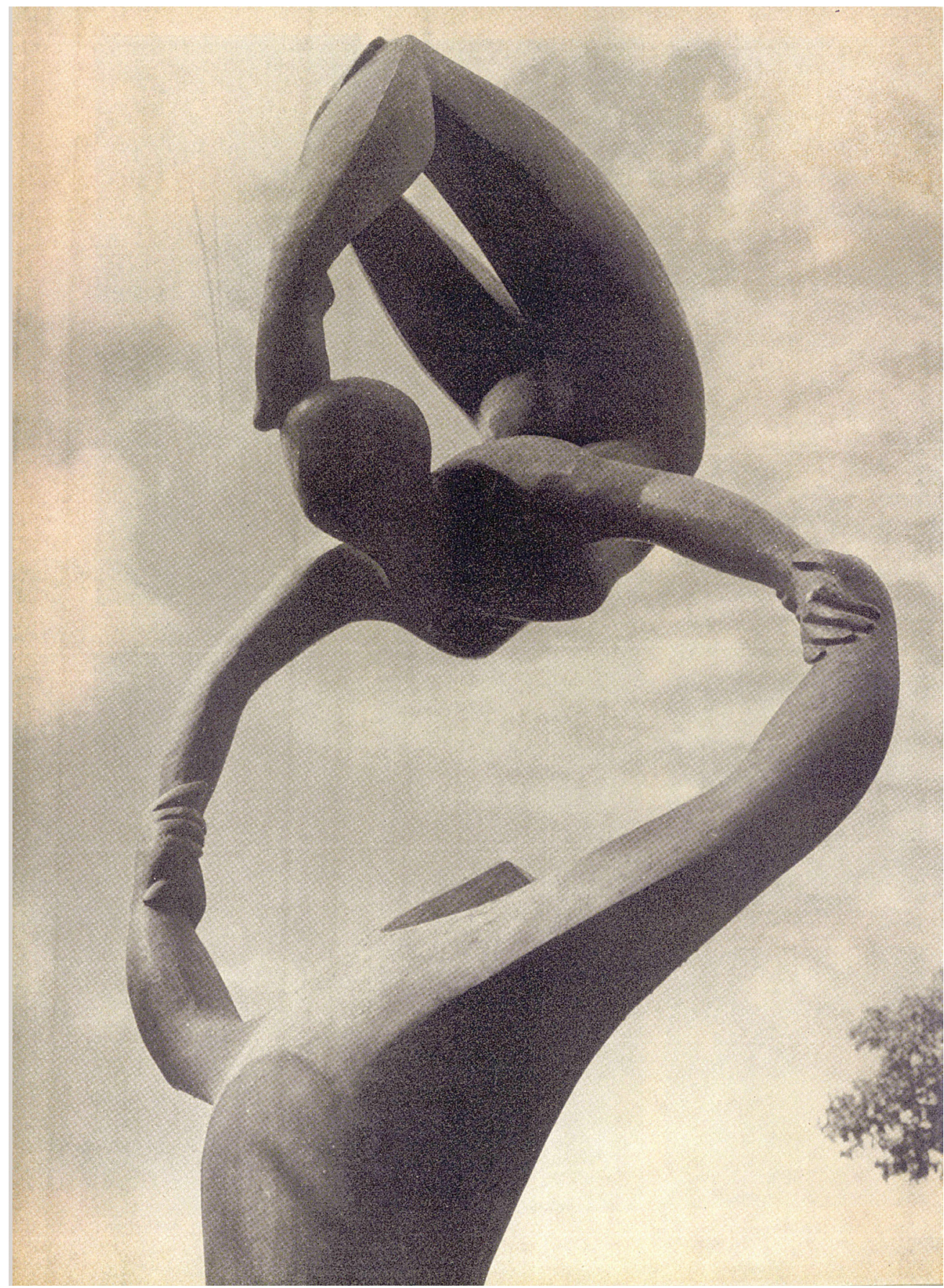

Figura 25 - Escultura de A. Ceschiatti, na Casa das Canoas, em foto com indicação de autoria a Marcel Gautherot, Módulo n 5, setembro de 1956.

até o n 12 é uma "revista de arquitetura e artes plásticas", nos nos 13 e 14 consta "revista de arquitetura e artes", e do no 15 em diante "revista de arquitetura e artes visuais no Brasil". Há referências constantes à atualidade artística de pessoas de 
54. Expressão de Véronique Boone (2005). círculos ligados ou não a seus redatores - as omissões e os destaques não são jamais inocentes nesses casos, reafirmando redes de relações pessoais ou institucionais. Tomemos o caso da reportagem da Módulo n 4 sobre o "jovem fotógrafo profissional" Otto Stupakoff, que busca a fotografia "como verdadeira forma de arte", e se representa na foto como um dândi de camisa social e gravata (sabe-se que ele se notabilizou em portraits e como fotógrafo de moda), com condições de construir um moderno ateliê "projetado por ele", retratado na matéria. $\bigcirc$ texto laudatório, típico de matéria paga, promocional, ou dado a relações com membros da revista, destaca seus estudos nos Estados Unidos, na Art Center School de Los Angeles; não se pode imaginar Marcel Gautherot em uma reportagem desse gênero: de origem modesta, simpatizante do comunismo, aprendeu o métier na prática, nos meios intelectuais parisienses dos anos 1930, e mais tarde, uma vez no Brasil, enquanto funcionário intermitente do SPHAN, estava em constante deslocamento, como os demais fotógrafos de sua geração, revelando e armazenando suas fotografias em condições precárias. Gautherot vem de outra geração, pouco preocupada com a promoção social de si e da profissão. A serviço de Niemeyer na Módulo, fornecia fotos sobre a cultura material e imaterial e, especialmente sobre a arquitetura, gênero que foi muito tempo considerado trabalho de um "artesão tecnicamente competente"54 e não de um "artista profissional" como o exemplo acima.

Uma série de fotografias avulsas de arquitetura sem identificação, em caderno especial incluso no artigo de Oscar Niemeyer denominado "Considerações sobre a Arquitetura Brasileira", na Módulo n 7, de fevereiro de 1957, são reconhecidamente de Marcel Gautherot. As considerações e croquis do arquiteto dialogam com fotografias de obras exemplares e incluem mesmo um panorama de Ouro Preto, lembrando a relação entre tradição e modernidade que animava intelectuais e artistas brasileiros daquela geração (Figuras 26 e 27).

artigo apresenta-se crítico e didático e denuncia o "baixo nível arquitetônico", o "emprego inadequado de certos materiais e o abuso de formas", erros de escala e proporção de elementos característicos de "nossa" nova arquitetura, apropriados "lamentavelmente" em pequenas "casas modernas" de "gosto popular". $\bigcirc$ artigo explica ainda a substituição dos pilotis pelas colunas em "V" ou em "W" em grandes obras, não só brasileiras (Parque Ibirapuera em São Paulo, Feira da Reconstrução em Berlim, Hospital Sul América no Rio, Conjunto JK em Belo Horizonte, Unité d'Habitation, em Marselha), reitera elogios a Le Corbusier, e destaca os demais elementos da arquitetura moderna como o emprego racional de arcos conjugados, de coberturas, de brises-soleil e de outros elementos de acabamento externo lazulejos no MES, cerâmicas das fachadas do Parque Guinle), e a condição fundamental dos projetos modernos, ou seja, de disporem de espaços livres e de jardins. As fotografias parecem ter sido escolhidas para o texto e o reforçam, sugerindo o entendimento entre o arquiteto e o fotógrafo, autor da maior parte delas. 


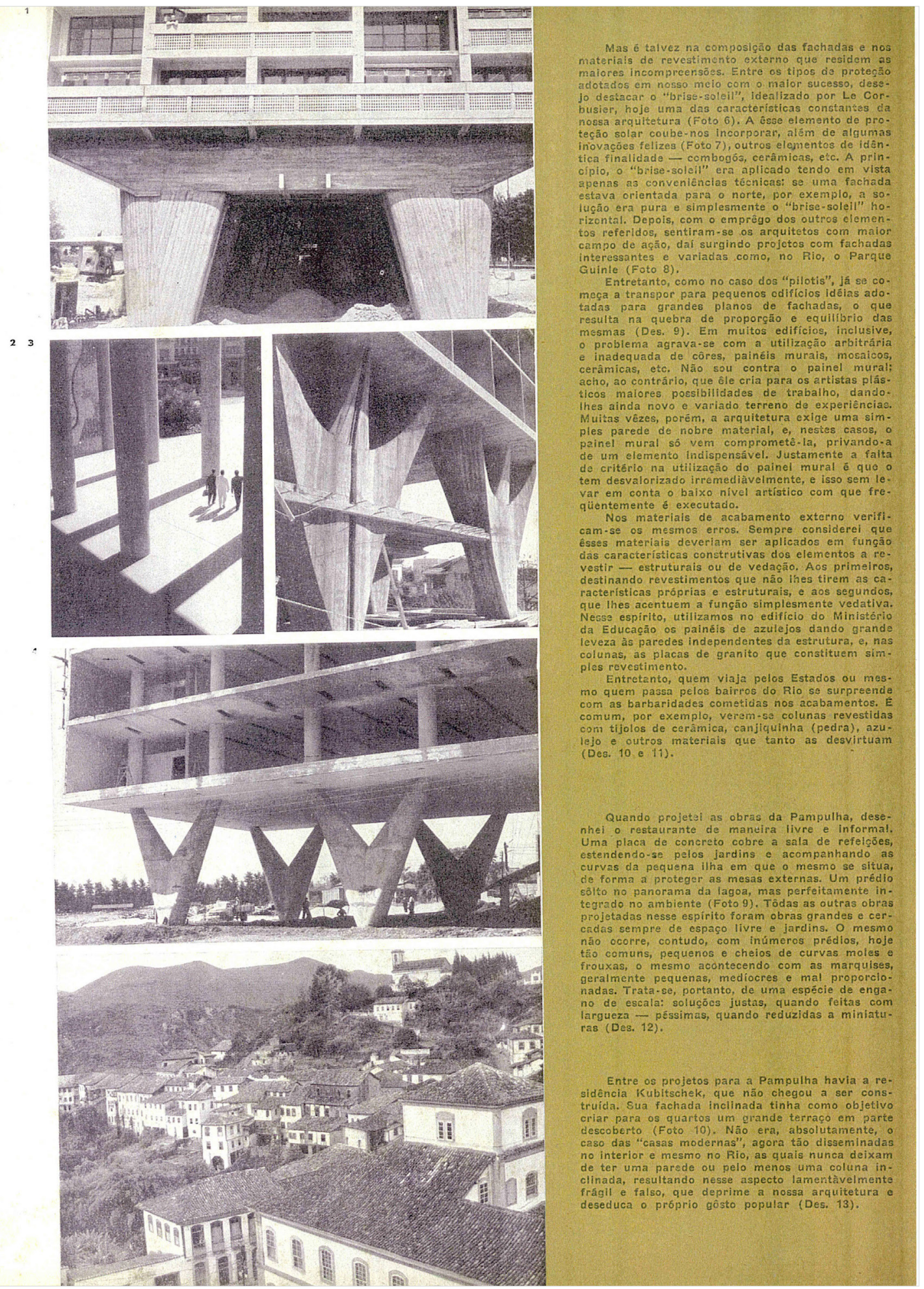

Figura 26 - Seleção de fotografias do artigo de Oscar Niemeyer "Considerações sobre a Arquitetura Brasileira", Módulo no 7, fevereiro de 1957. 


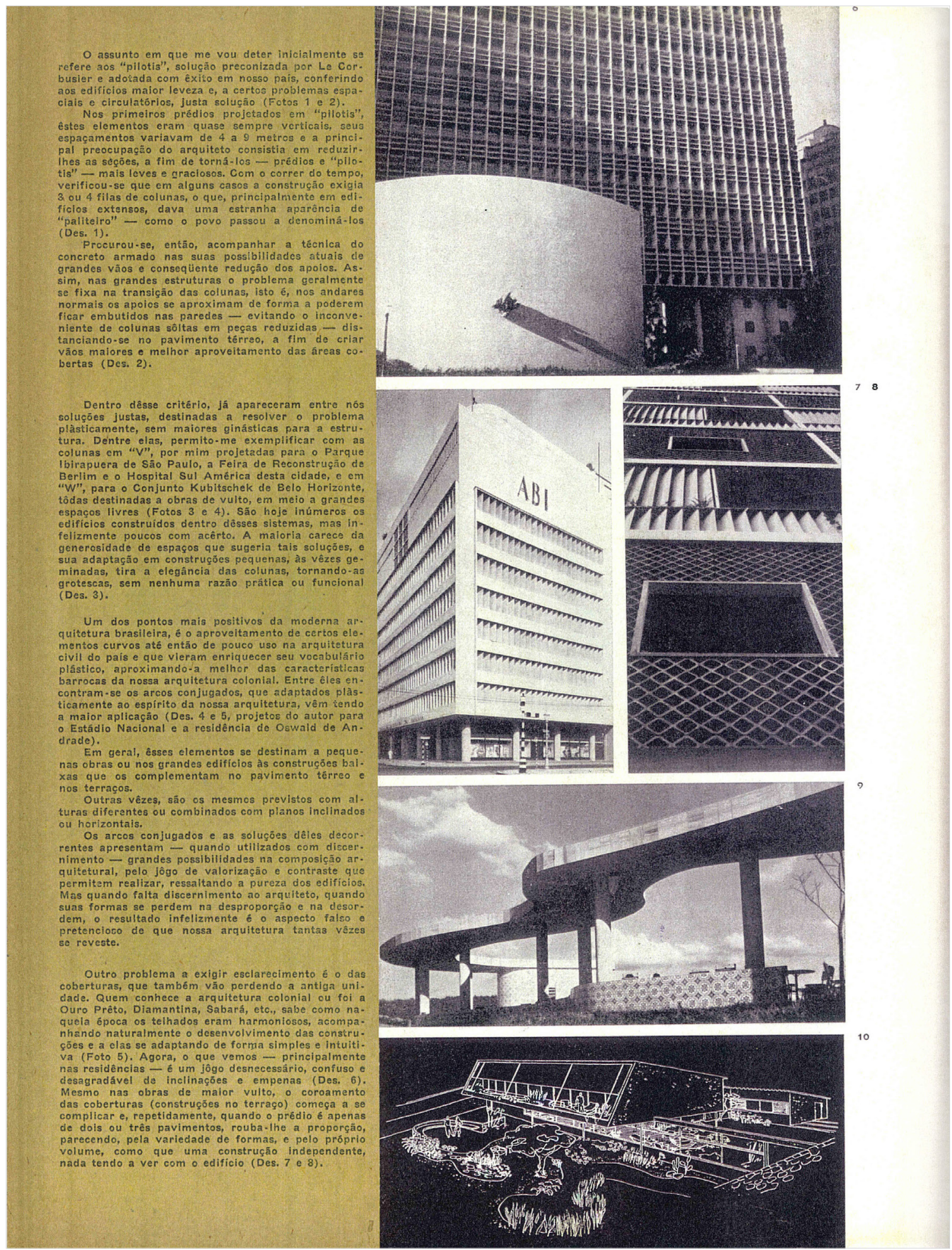

Figura 27 - Seleção de fotografias do artigo de Oscar Niemeyer "Considerações sobre a Arquitetura Brasileira", Módulo n 7, fevereiro de 1957. 
A encomenda para fotografar a construção da nova capital foi um momento decisivo na carreira e difusão nacional e internacional da obra de Marcel Gautherot como fotógrafo da arquitetura moderna, trabalho que havia começado no Rio e em Minas Gerais nos anos 1940, registrando as obras de Niemeyer e a de outros arquitetos, cujas fotografias já estavam presentes em números especiais de revistas estrangeiras, como foi mencionado neste artigo.

Módulo foi um veículo de grande relevo para a consagração nacional e internacional definitiva do modernismo arquitetural brasileiro ${ }^{55}$, tendo sido criada, de fato, para funcionar como suporte de divulgação da construção de Brasília, tema que ocuparia cada vez mais espaço na revista. Vimos que sua política editorial foi marcada por um desejo de internacionalizar-se e de ser moderna e que, nas matérias, a nova arquitetura coabita com a valorização de tradições culturais de cunho regionalista (associação que se manifesta em alguns países, não apenas no Brasil, desde os anos 1930|, considerando-as como partes da simbiose afirmativa da identidade nacional.

ano de 1955 pode ser considerado como a abertura de uma nova fase de reflexão e de maturidade da arquitetura de Niemeyer, após o período em que monografias e revistas internacionais já haviam discutido e divulgado sua obra, incluindo fotos de Marcel Gautherot. Niemeyer cria então seu próprio veículo de imprensa para difundir suas idéias, seu trabalho, o de seus companheiros, e os princípios da nova arquitetura brasileira ${ }^{56}$, intenção explícita nos artigos críticos assinados por ele e na importância conferida aos números da Módulo sobre a construção de Brasília, evento para o qual deviam voltar-se os olhos do mundo. Na abertura da Módulo n 8, de julho de 1957, assinala-se "Edição especial: Brasília a nova capital do Brasil, tiragem de 11.000 exemplares, texto em português e alemão, e uma separata em francês e inglês". Mais tarde, na Módulo n 18, de junho de 1960, comprova-se o alcance da inauguração na "imprensa mundial", com a publicação de três páginas com recortes de diversos jornais internacionais noticiando o feito (Figura 28).

A revista revelou-se (no sentido fotográfico da palavra), um dispositivo que conseguiu tornar visível a "cena arquitetural" geograficamente localizada, mas inserida num movimento internacional, estratégia de todo periódico de arquitetura moderna $^{57}$. Os primeiros passos para essa revelação de Brasília começaram na Módulo n 6, de dezembro de 1958, seja no design da capa ou nas fotos das maquetes e dos esboços (atribuídas a Flávio Damm), seja em artigos relativos ao "Palácio Residencial", cujo projeto se modificaria logo depois.

A capital vai então tomando forma e se impondo nas representações combinadas pelo projeto gráfico no espaço da página - a mis en scène da arquitetura moderna em fotos de montagens de croquis associados às maquetes de projetos faz parte do processo de intencionalidade de sua visualização nas revistas ${ }^{58}$; Niemeyer assim procede, além de criar muitas das legendas explicativas.
55. Sabe-se que a revista Módulo era voltada para as obras do Rio de Janeiro e em seguida para as de Brasília; no caso do modernismo paulista, a referência é a revista Acrópole.

56. Ao revisar este artigo, tomei conhecimento de um ensaio incontornável de Ruth Verde Zein (2012) sobre os textos de Oscar Niemeyer publicados em vários números da Módulo (alguns citados aqui), relativos à critica internacional de sua obra e explicitando as próprias posições do arquiteto em relação a ela.

57. As análises de Hélène Jannière (2002, p. 338-341) sobre as revistas de arquitetura constituíram uma referência estimulante para minhas reflexões sobre a representação fotográfica da arquitetura brasileira; agradeço a esta autora as longas conversas em Paris sobre a questão.

58. Ver Hélène Jannière (2002, p. 90ss). 


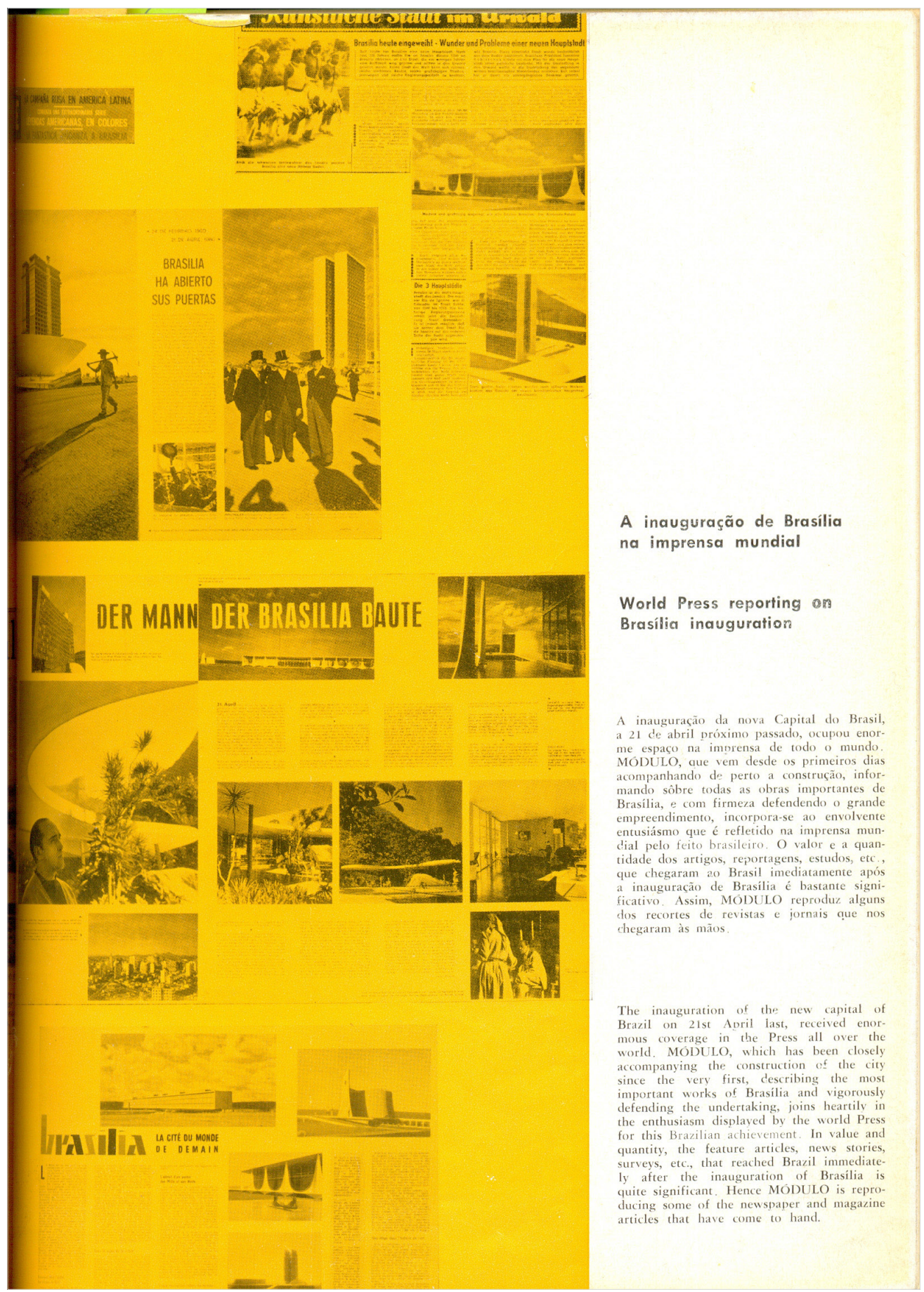

Figura 28 - Reprodução de recortes sobre "A inauguração de Brasília na imprensa mundial", Módulo n० 18, junho de 1960.

Esses dispositivos visuais passam a figurar nas capas e em reportagens que destacam virtualmente a imagética da capital por vir (Figura 29). 


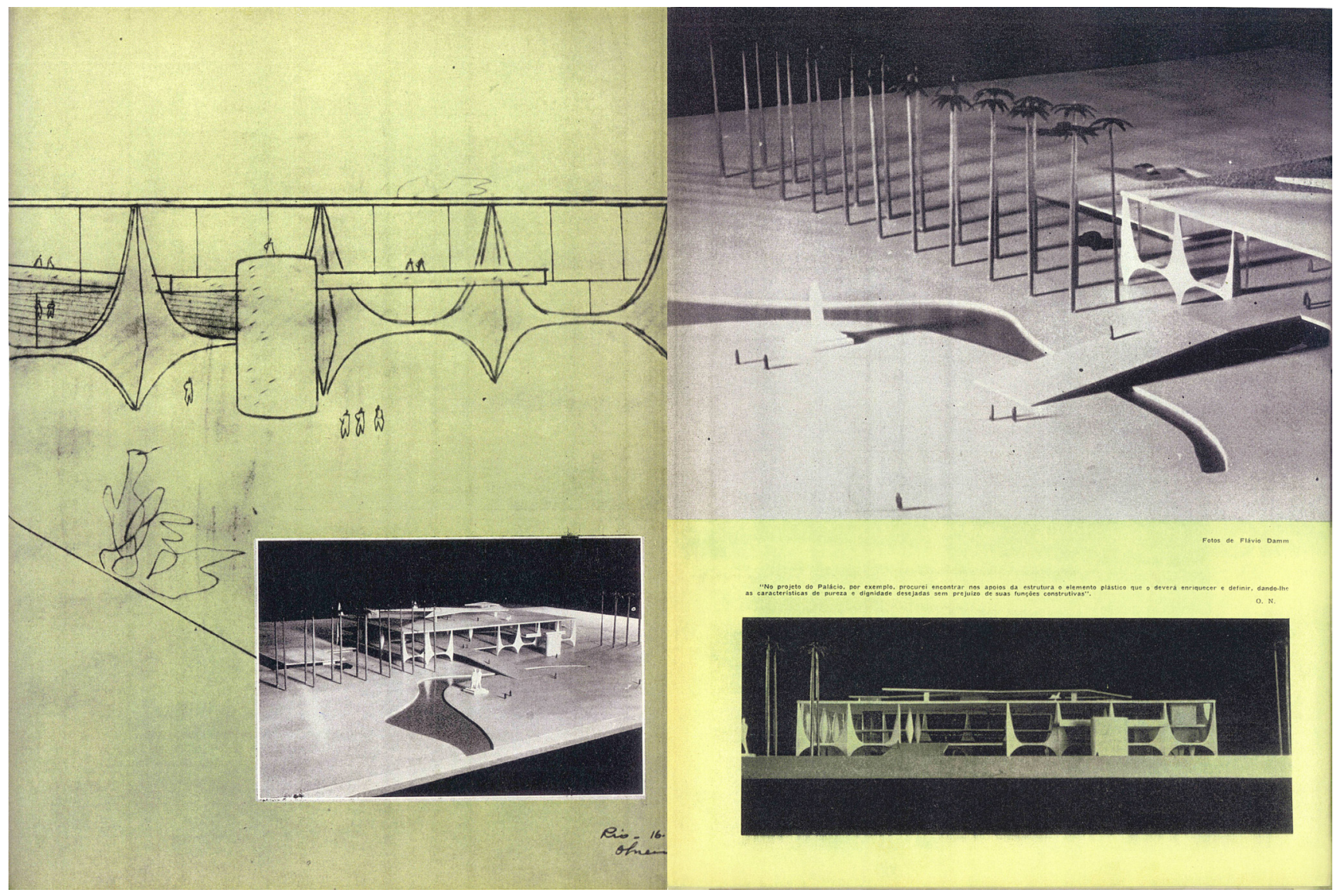

Figura 29 - Dispositivos visuais (maquetes e croquis fotografados) promovem Brasília a partir da Módulo n 6, dezembro 1958.

A Módulo n 8, traz a "reportagem completa sobre o concurso de anteprojetos do plano piloto", em que o $5^{\circ}$ premiado (Villanova Artigas e outros) inclui curiosamente um desenho de Percy Lau, extraído da série "Tipos e Aspectos do Brasil", Boiadeiro e sua tropa, cena representativa da região Centro-Oeste, onde se construiria a capital.

A Módulo n 9, de fevereiro de 1958, mostra "Brasília em exposição permanente", montada no Rio de Janeiro, exposição cujo projeto era de Arthur Lício Pontual (então responsável pelo layout da Módulo), exibindo fotografias, croquis e maquetes do andamento da construção, mostra essa que teria, entre outras, incluído fotografias de Gautherot e sobre a qual farei comentários mais adiante. Nos painéis dessa exposição, assim como nas capas e reportagens ilustradas por fotografias de maquetes e perfis (números 9, 10 e 11), destacam-se imagens em que se procede ao gesto analítico de recortar partes significativas que compõem a nova arquitetura - as colunas do Alvorada e os montantes da Catedral - como dispositivos visuais que a promovem e a difundem. Na Módulo n 10, de agosto de 1958, um artigo de Joaquim Cardozo "Forma estática e forma estética" exibe quatro fotografias sem atribuição que destacam, no sentido transversal e longitudinal, os 
pilares desenvolvidos em leque dos palácios da Alvorada, do Planalto e do Supremo Tribunal. Já a Módulo n 11, de dezembro de 1958, refere-se, sobretudo, à Catedral de Brasília, da capa - com design significativamente interessante de Glauco Campelo utilizando uma visão tecnológica e tectônica do alto da maquete - à longa reportagem que associa fotos, esboços e texto explicativo de Oscar Niemeyer (Figura 30).

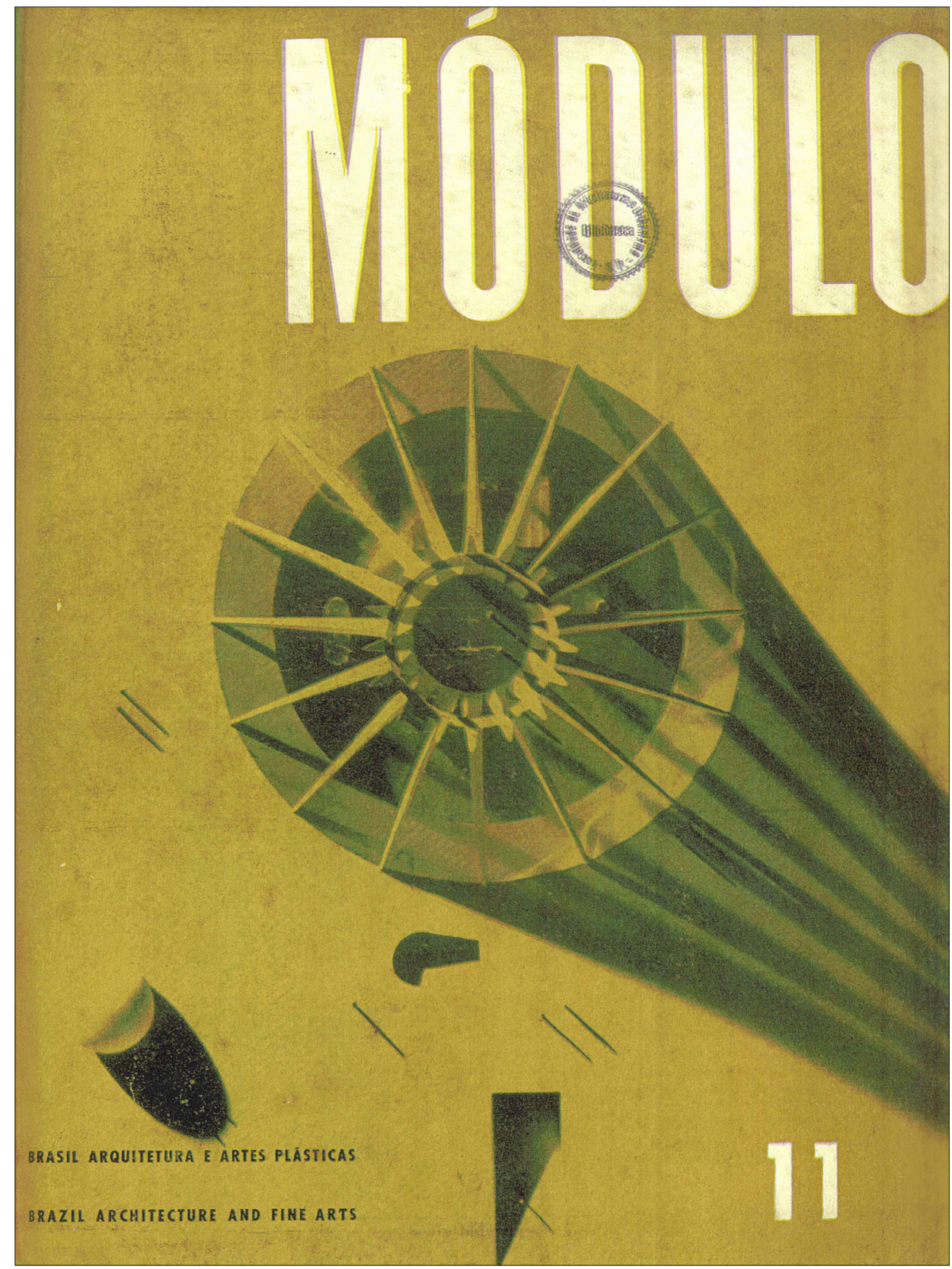

Figura 30 - Capa da Módulo n 11, dezembro de 1958, demonstrando a qualidade do layout de Glauco Campelo que retrata a Catedral de Brasília. 
As primeiras fotos da arquitetura de Brasilia de que se conhece como sendo de Marcel Gautherot lembora estejam sem créditos, mas passíveis de identificação por meio dos contatos arquivados no IMS), estão na Módulo n 12, de fevereiro de 1959; são 14 imagens retratando a decoração interior do Palácio Presidencial e do Brasília Palace Hotel: trata-se de vistas gerais que destacam a perspectiva das salas exibindo a decoração interior como para "testemunhar uma realidade bem viva" e não "um projeto abstrato", como escreveu o embaixador do Brasil em Paris, ao apresentar o caderno especial de L'Architecture d'Aujourd' hui, em 1958. $\bigcirc$ n 12 da Módulo inclui também fotografias sem atribuição sobre as unidades residenciais de Brasília em artigo de Lucio Costa, além de desenhos e maquetes de projetos de Niemeyer para o Instituto de Aposentadoria e Pensões dos Bancários e para o Museu de Brasília, obras essas a serem construídas.

É ainda na Módulo n 12 que reconhecemos uma grande foto avulsa de Gautherot, sem atribuição, na página à direita da do expediente; essa foto se inscreveria no âmbito de um humanismo documental também presente em séries do seu acervo: ela representa a multidão de populares de costas no enterro de Bernardo Sayão, em Brasília - note-se que fotos nesta linha foram raramente publicadas na Módulo (Figura 31 1). A tomada segue uma tendência dos fotógrafos da vanguarda de fotografar "os que olham" um acontecimento (alheios ao fotógrafo, e muitas vezes de costas) e não o objeto do olhar ${ }^{59}$.

Abro um parêntese para registrar que, uma vez morando em Brasília para fotografar o andamento das obras, Gautherot voltou-se também para o horschamp do plano piloto, para o habitat precário dos trabalhadores, vida paralela, germe das extensas cidades-satélites que cercam hoje a capital. A descrição da pobreza em Gautherot busca documentar o real sem miserabilismo ou exploração sensacionalista no gênero "estética da miséria". Lembremo-nos que tanto a habitação social como a vernacular foram temáticas pela quais ele se interessou desde a juventude (vide seu discurso de Sohlberg, em 1930), e que voltam nas tomadas que fez do casario brasileiro. Da mesma forma, os retratos de homens e "mulheres do povo" liá presente nas fotografias sobre o México em 1936, e que dá nome a uma das séries de seu projeto de photo-book, mais tarde, no Brasil), são tomados como um documento social ou etnográfico. Mulheres e crianças diante dos casebres e candangos indo para o trabalho constituem um dossiê sobre um aspecto da Brasília nascente que o fotógrafo não conseguiu publicar: "Eu quis ir muito longe, eu quis mostrar as favelas, as cidades-satélites. Teria a possibilidade de fazer um livro sobre Brasília com isso... Recusaram porque era muito feio..." 60 .

○úmero seguinte é a Módulo n 13, de abril de 1959, (ver Figura 8) que ostenta a significativa capa "construtivista" que já analisei anteriormente, mostrando detalhe das estruturas, captado por Gautherot em fotografia que the é atribuída, retrabalhada por Pontual. O número não traz a relação capa-reportagem, como era de praxe, pois não há imagens da mesma linha nas páginas internas da revistab ${ }^{6}$.

\begin{abstract}
59. Recentemente o tema foi tratado em exposição realizada em Paris no Centre Georges Pompidou e catálogo dirigido por Clément Chéroux (2013). Lê-se nos textos da mostra que para este fotógrafo (que Gautherot admirava), "como para muitos outros que se reconheciam nas idéias do comunismo, a um momento ou outro, a multidão encarna o poder do povo, isto é, a esperança revolucionária". Cf., no catálogo citado, o pequeno texto sobre "Le siècle des foules" (2013, p. 338).
\end{abstract}

60. Cf. Entrevista que Marcel Gautherot concedeu a Lygia Segala a 07/12/1989, no Rio de Janeiro, já citada.

61. Estas fotografias de Gautherot só vieram a ser publicadas por mim em 2007 no catálogo que organizei por ocasião da mostra na FAAP e em comunicação sobre Brasília (ver Heliana Angotti-Salgueiro, 2008); aprofundei a análise em "Brasília, ville radieuse photogénique", texto apresentado em La Chaux de Fonds em 2010, em vias de publicação. 


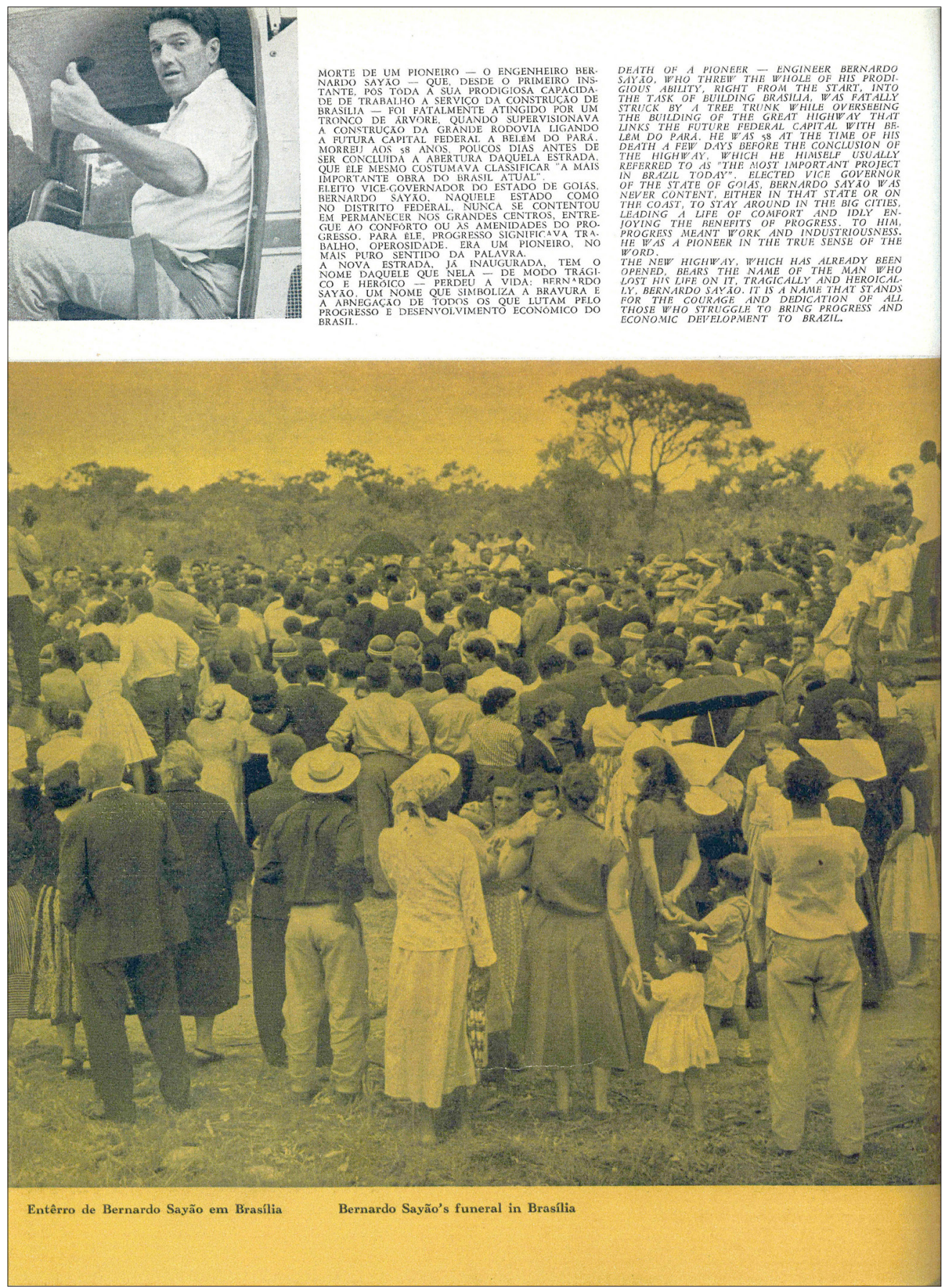

Figura 31 - Fotografia de Marcel Gautherot (sem indicação de autoria), no funeral de Bernardo Sayão, em Brasília. Módulo n 12, fevereiro de 1959.

Na Módulo n 14, de agosto de 1959, três grandes fotos de Gautherot sem atribuição retratam o Palácio da Alvorada, inseridas no artigo "Brasília vista por um inglês", de J. M. Richards - um dos representantes de seu país nos CIAMs 
e editor da Architectural Review, em que sempre deu destaque para a arquitetura moderna brasileira, como no número especial em março de 1944 e, em 1950, o Report on Brazil. Parece que o olhar estrangeiro ainda precisava ser convocado para testemunhar a magnitude épica do empreendimento e as fotos cumprem o postulado de Le Corbusier, "sob tal luz a arquitetura nascerá" - e ela nasce antes da cidade nos volumes geométricos que se destacam no vazio empoeirado do planalto, tão adequado ao projeto modernista, que requer um novo espaço para se implantar, e nas formas livres, destacadas nas perspectivas e perfis iluminados do Palácio da Alvorada, o primeiro a ser construído. $\bigcirc$ olho fotográfico de Gautherot pode ser reconhecido em muitas fotografias que não recebem atribuição, como na página que inclui um enquadramento através de esquadria que destaca a perspectiva de efeitos de sombra da vista do hotel, e a imagem frontal do esqueleto do Congresso em construção (Figura 32).

A partir da Módulo n 15, a revista tem o formato diminuído lpassa de $25 \times 35 \mathrm{~cm}$ a $22 \times 29 \mathrm{~cm}$ ); na capa nota-se a articulação de croquis e duas fotografias de Gautherot que, nas páginas internas, vão se associar significativamente a um terceiro elemento, o texto, no artigo "A imaginação na arquitetura", de Oscar Niemeyer. A busca de "diversos pontos de vista" assinalada pelo arquiteto, com a representação dos olhos e das linhas que saem deles ("o olho que anda" das vanguardas...), é retomada pelo fotógrafo ao captar o objeto arquitetural no espaço infinito sob diferentes ângulos, respondendo a verbos de movimento, como "percorrer": primeiro contornando-o de longe, em seguida se aproximando da obra para sentir sua escala e o espaço que a cerca, para afinal entrar na mesma (sob o peristilo das colunas do Palácio da Alvorada), captando o perfil de suas formas que se agigantam graças ao ângulo fotográfico, e se espelham no solo molhado até a capela, ao fundo, que funciona como ponto de fuga da cena. Gautherot se esmera na busca de pontos de vista inéditos e monumentais destacando os perfis em "leque" das colunas, reiterando os esboços do arquiteto, para descrever e fixar ora a esbelteza, reflexos, texturas e materiais, ora as sensações de volume no espaço, no caso dos palácios do Planalto e do Supremo Tribunal Federal (Figura 33).

Nessa edição da Módulo n 15, compõem a capa fotos das estruturas das cúpulas do palácio do Congresso em construção sendo trabalhadas pelos operários, sem créditos na página do expediente; porém, na reportagem interna, quatro fotografias da mesma série são devidamente atribuídas a Gautherot - nelas a "visão em movimento"62 do fotógrafo o aproxima dos operários que preparam a armação dos ferros antes da concretagem. Busca de efeitos estéticos em cena real, porém longe da abstração de outros contatos "desumanizados", como as da série da capa da Módulo n 13, efeitos também buscados pelo diagramador que aplica cor nas fotos e as dispõem alternadamente em quadrados na página, reservando um quadrado para a frase que distingue o fotógrafo: "Fotos de Marcel Gautherot".

Ainda nesse número 15, aparece também a hoje célebre fotografia dos Ministérios em obras, sem atribuição, embora o nome de Gautherot esteja
62. Expressão de Olivier Lugon (2000) 

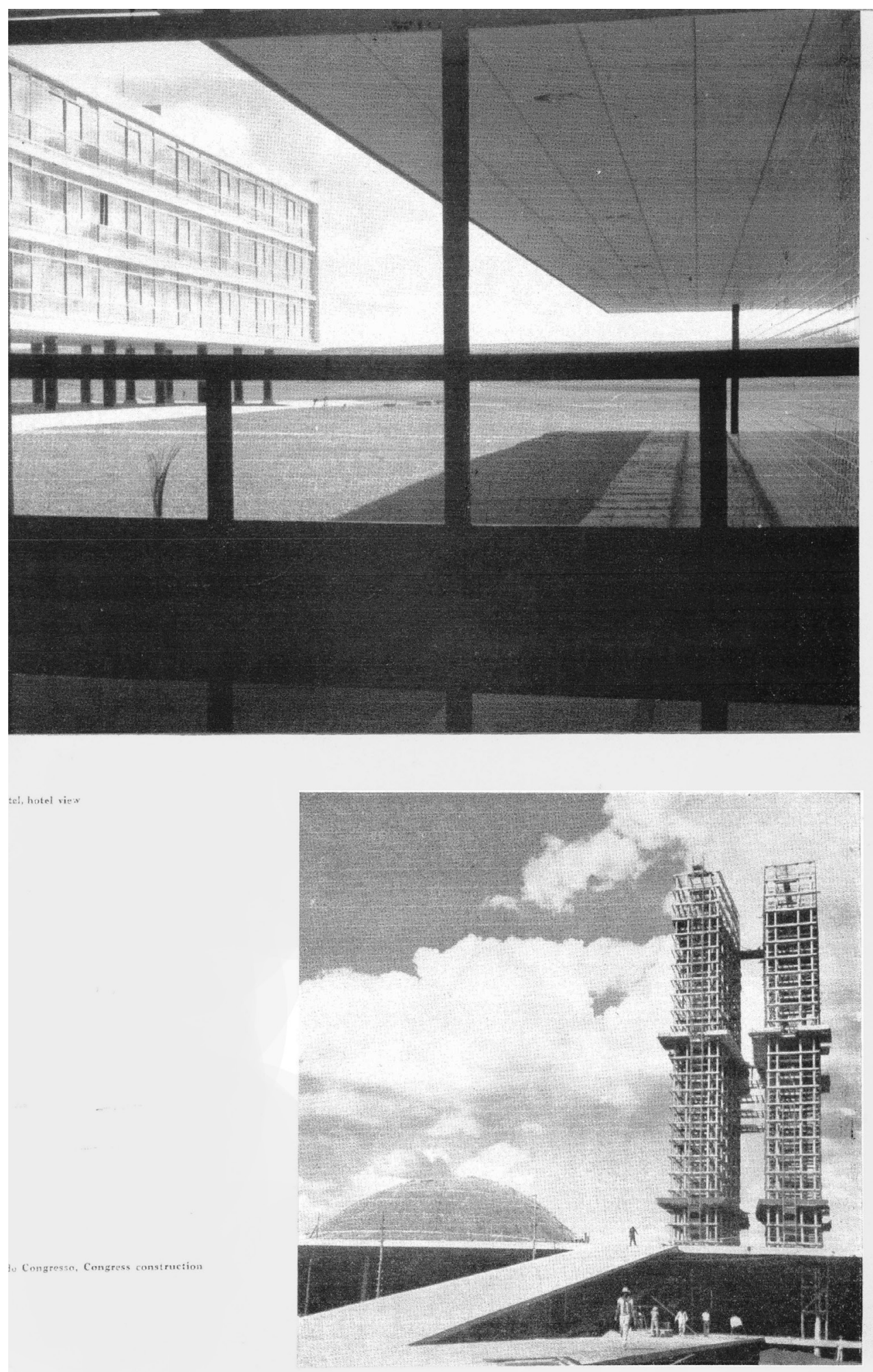

Figura 32 - Página da Módulo n 14, agosto de 1959 

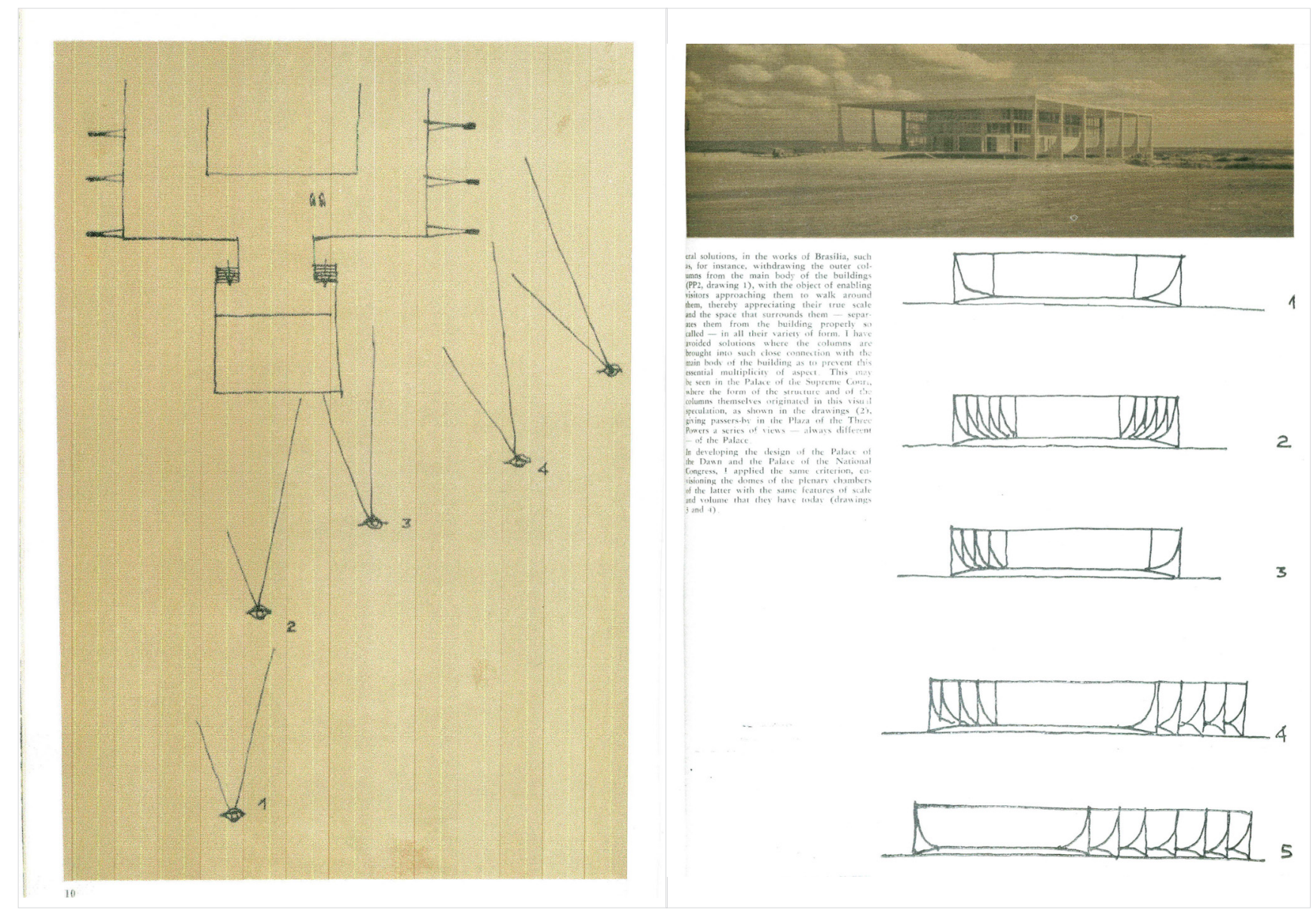

Figura 33 - Palácio do Supremo Tribunal Federal em fotografia de Marcel Gautherot e esboços de Oscar Niemeyer, páginas da Módulo n 15, outubro de 1959.

destacado no artigo mencionado acima; a fotografia está na abertura da revista, em página inteira, à esquerda do "Poema" de Joaquim Cardozo dedicado "ao arquiteto-poeta Oscar Niemeyer, a Manuel Bandeira, a João Cabral de Mello Neto e a Thiago de Mello, arquitetos da poesia". Já comentei em textos anteriores o efeito de uma miragem ou transfiguração da realidade que encerra a imagem da estrutura metálica dos edifícios saindo da poeira, acima da linha do horizonte que divide a foto, em que os operários aparecem minúsculos e as sombras gigantescas das estruturas das construções do lado oposto, a ocuparem o primeiro plano efeito da desmaterialização das formas, paradoxalmente construtivista ${ }^{63}$.

As revistas Módulo no 16 e n 17, publicadas em dezembro de 1959 e abril de 1960, contam com os artigos "A propósito de Brasília" e "Problemas e perspectivas de Brasília", respectivamente assinados por Amâncio Williams (arquiteto do Movimento Moderno argentino, que foi responsável pelas obras da Casa Curuchet de Le Corbusier, em La Plata) e por Sir William Holford (arquiteto e professor de planejamento urbano na University College, em Londres, que participou do júri de
63. Estas observações (bem como o título desta parte) foram retomadas da comunicação "Marcel Gautherot et la naissance photographique de Brasília", apresentada em La Rochelle, em 2005 , e publicada em Laurent Vidal (2008); ver também Heliana Angotti-Salgueiro (2007b, p. 276). 
seleção do plano piloto de Brasília) - artigos que são ilustrados com fotografias da Esplanada dos Ministérios em obras, sem autoria. Além destes textos de apoio à cidade em construção, a revista mantém matérias visuais sobre projetos em andamento, com esboços e fotos de maquetes (Jardim de Infância, teatros oficiais...). A prática de publicar artigos de arquitetos e críticos conhecidos internacionalmente ocupou números da revista que precedem a inauguração da capital; na Módulo nº 17, de abril de 1960, Aline Berstein Saarinem completa o time - jornalista americana e crítica de arte e arquitetura que era então casada com o arquiteto Eero Saarinem, assina "Surge Brasília" (originalmente publicado no New York Times em 18 de outubro de 1959), ao lado de uma fotografia sem atribuição, cujo enquadramento destaca o perfil da "coluna" sob o peristilo do Palácio do Planalto (Figura 34).

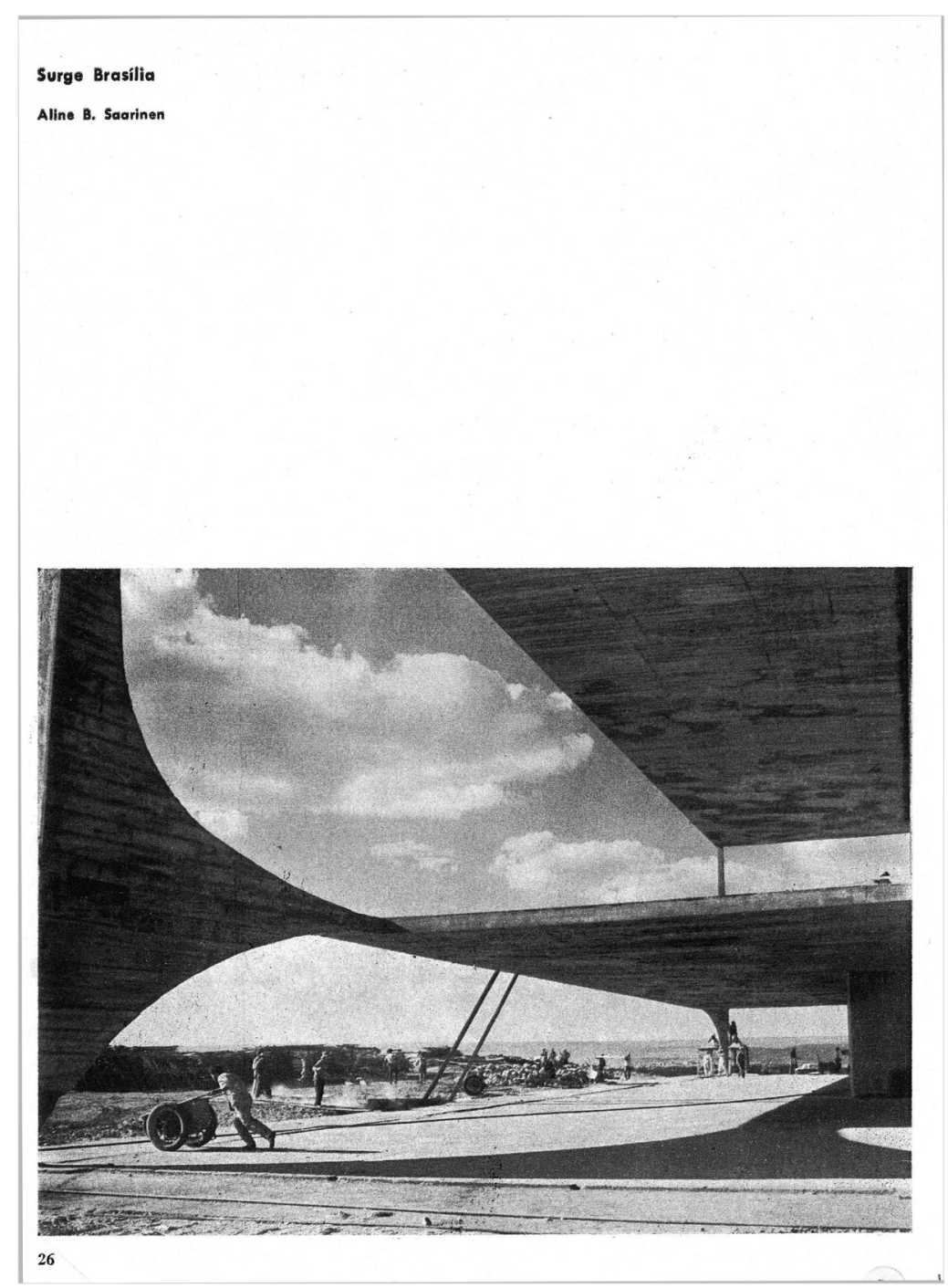

Figura 34 - Página da Módulo n 17, abril de 1960, com detalhe do Palácio do Planalto em construção, fotografia sem crédito de autoria. 
A Módulo n 18, de junho de 1960, inclui no início, e a título de fechamento, cadernos de publicidade sobre Brasília e abre com uma vista da cidade em construção ao lado de texto de conferência de Roland Corbisier pensador desenvolvimentista de esquerda, de família tradicional pernambucana, que era então diretor do ISEB ligado ao MEC -, "Brasília e o desenvolvimento nacional", sobre as condições de possibilidade "políticas, ideológicas, culturais e históricas" da transferência da capital. Mas o mais relevante para nosso estudo é o artigo seguinte, uma espécie de depoimento histórico-retrospectivo de Oscar Niemeyer "Minha experiência de Brasília", com 14 fotografias sem atribuição. No texto, expressões como "empreendimento extraordinário", "tarefa gigantesca", "aventura", "cruzada", "espírito de luta" comunitário, dão o tom épico da "experiência" vivida para fundar a capital. As representações sobre os projetos dos edifícios principais comportam adjetivos que as aproximam daquelas de tratados clássicos do século XIX da formação acadêmica: "encontrar uma forma clara e bela de estrutura (...) dentro do critério de simplicidade e nobreza (...) proporcionando aos visitantes da nova capital, uma sensação de surpresa e emoção que a engrandecesse e a caracterizasse". Niemeyer cita sua lembrança do "impacto indescritivel pela beleza e audácia plásticas" da Praça de São Marcos, do Palácio dos Doges e da catedral de Chartres, em recente viagem à Europa.

Entre as 14 fotografias reconheço que oito de arquitetura e duas de vistas da cidade são certamente de Marcel Gautherot, embora não the sejam dados os devidos créditos em matéria tão importante; quase todas estão acompanhadas de legendas extraídas do texto, que dialogam com elas como se estivéssemos diante de uma "criação partilhada", "colaboração orgânica (...) criação sobre outra criação"64, em que o fotógrafo, habitante temporário da cidade como fora o arquiteto, revela-se também arquiteto escolhendo o ângulo correto desta "arquitetura rica de formas e ao mesmo tempo sóbria e monumental", o perfil dos volumes e sua relação com o espaço e a luz que define essas formas "claras e belas (...), a atmosfera de digna monumentalidade", "a leveza das estruturas" e, num outro registro, que não poderia faltar - o do pensamento humanista que ambos, arquiteto e fotógrafo partilhavam - capta-se o "espírito de sacrifício dos operários, verdadeiros e modestos heróis desta esplendida jornada" 65 .

A ordem das fotografias é a de uma narrativa fundadora: após a foto aérea do território vazio, a primeira visita da comitiva em marcha com o arquiteto, - Catetinho, os operários. Seguem-se as fotografias da fachada do Palácio da Alvorada em perspectiva lateral, a visão frontal do Congresso, a Catedral em obras, e a página inteira com o gros plan da cúpula invertida sob cor amarelada que se insinua no corte sobre a laje de concreto, verdadeiro évenement plastique (expressão que tomo a Le Corbusier), com sua geometria agigantada, quase abstrata, em contraste com o minimalismo de dois personagens ao fundo (ver Figura 9). Naquele momento, Gautherot já estava consciente do papel de sua fotografia como uma criação e não apenas como um registro documental e anônimo para a promoção e difusão da linguagem da arquitetura moderna
64. Cf. expressões de Olivier Lugon (2003, p. 43).

65. Expressões de Oscar Niemeyer (1960b). 
brasileira, realizando tomadas mais pessoais como esta; a mesma liberdade criativa se dá com a foto aproximada dos operários amarrando os ferros, na cúpula invertida do Congresso - momento em que ele se coloca dentro da obra, évenement humain, além de "construtivo", o primeiro plano sendo reservado aos materiais (Figura 35).

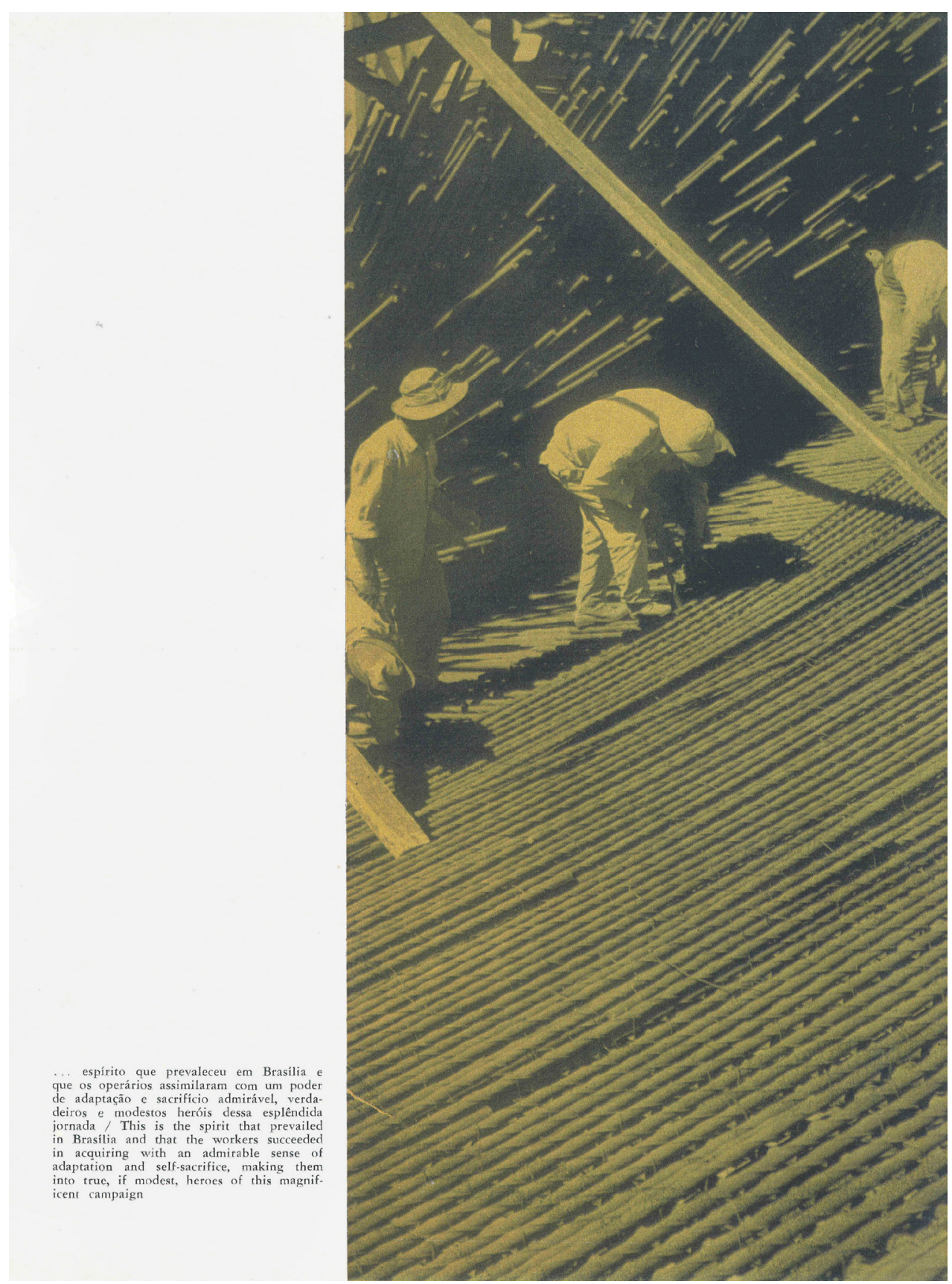

Figura 35 - Fotografia de Marcel Gautherot do interior da cúpula convexa do Congresso Nacional, Módulo n 18, junho de 1960. 
Na história da fotografia, o olho modernista pode se caracterizar pelo interesse na estrutura mais do que no edifício, sendo que naquela presume-se que a estética não seja intencional - assertiva discutível em casos como o de Gautherot, quando ferros e outros materiais comuns ganham plasticidade quando isolados num contato (como na capa já comentada da Módulo no 13). Desde a Bauhaus, que Gautherot conheceu na Alemanha em 1930, a fotografia da arquitetura já havia deixado de ser apenas ilustração documental, transformando-se em médium ideal capaz de apresentar a essência tectônica e visual dos edifícios ${ }^{66}$. Algumas fotos de canteiros de obras de Brasília mostram este enfoque físico da construção, se bem que em muitas delas ele inclua os operários executando tarefas, como o escoramento das formas em meio dos ferros e ripas de madeira. Este tipo de imagem é recorrente também em outros fotógrafos, como Lucien Hervé, que capta as obras de Chandigarh para Le Corbusier e que esteve em Brasília no começo dos anos 1960 e cujas fotos são próximas das de Gautherot.

Ainda no artigo de Niemeyer da Módulo n 18, há imagens que enfatizam o enquadramento e a distância espacial da obra: Gautherot foca a praça dos Três Poderes lantes da instalação da escultura Candangos, de Bruno Giorgil de dentro do Palácio do Planalto, usando a esquadria como moldura da foto; depois reproduz o edifício em duas tomadas frontais clássicas, mas demonstrando o que ele havia retido das leituras de Le Corbusier: a "luz como a base da arquitetura" e a "construção que se insinua no sítio". Seguem-se a fotografia do Palácio da Alvorada ao longe, que parece minúsculo captado no planalto vazio e sem vegetação, e uma visão aérea de parte da cidade. Se "a dimensão da monumentalidade é uma questão fundamental para entender as soluções urbanas adotadas em Brasília"67 - lembrando que Lúcio Costa a defendia sem grandeza ostentatória e incorporando outros valores como a natureza -, as soluções arquiteturais, por sua vez, assumem proporções modestas, sugerindo cuidado com a aplicação do conceito de monumentalidade à capital moderna, tema que vai além dos propósitos deste texto.

A Módulo n 19, de agosto de 1960, dá novamente a palavra a Sir William Holford em conferência "Sobre Brasilia", feita antes da inauguração, no Real Instituto de Arquitetos Britânicos. Revelada em vermelho, a foto em página dupla de Gautherot (não atribuída) enquadra através das esquadrias do Palácio do Planalto (du dedans vers le dehors) a Praça dos Três Poderes, com o edifício do Supremo Tribunal no centro, ao longe, "forma livre" no espaço largo e infinito; na foto dos Guerreiros ou Candangos de Bruno Giorgi inscrita na mesma praça, escultura retratada nas séries de Gautherot, não se dão tampouco créditos ao fotógrafo. Em todos os números desse ano há fotos avulsas de edifícios de Brasília, sem autoria.

Na Módulo n 21, de dezembro de 1960, repete-se a foto da cúpula invertida (Figura 9), novamente sangrando a página, desta feita revelada em forte cor azulada, em artigo de Niemeyer, "Forma e função na Arquitetura". Esta repetição de fotos acontece algumas vezes na Módulo, e sugere que o leque de fotografias à disposição não era tão vasto, apesar do grande número de contatos feitos por
66. Reflexões a partir Andreas Haus (1997). Ver, a respeito, Heliana Angotti-Salgueiro (no prelo).

67. Ver, entre outros, José Pessoa (2010/2012, p. 23), que relembra a frase de Lewis Mumford (The Culture of Cities): "If it is modern, it cannot be a monument" Sabe-se que a associação monumentalidade/totalitarismo caracterizou o pensamento dos anos 1930 e persistiu na historiografia por um bom tempo. 
68. Expressões e frase de Oscar Niemeyer (1960b), que associaríamos à conhecida fotografia da família de candangos na inauguração de Brasília, por René Burri, que não pode ser publicada aqui.

69. A revista Acrópole costumava não só citar no expediente os fotógrafos, mas especificar as páginas em que publicavam suas fotografias - a exemplo, no número 211, em 1956 constam Michel Aertsens, p. 266 a 271, e José Moscardi, págs. 272, 273, 283 e 285.
Gautherot em Brasilia, que seu acervo revela hoje. O texto é uma tomada de posição diante das imposições radicais do funcionalismo, em que o arquiteto defende a procura de soluções novas e variadas de uma arquitetura com liberdade plástica sem medo das contradições da forma com a técnica e a função: o exemplo dado por Niemeyer, que Gautherot e outros fotógrafos souberam explorar em suas fotografias, é a "forma dos suportes ou das colunas" dos palácios da Alvorada, do Planalto e do Supremo, muitas vezes focadas de perto para mostrar o que o arquiteto queria:

\begin{abstract}
formas que não se apoiassem no chão, rígidas e estáticas como uma imposição da técnica, mas que mantivessem os palácios como que suspensos, leves e brancos, nas noites sem fim do Planalto. Formas de surpresa e emoção que, principalmente, alheassem o visitante - por instantes que fossem - dos problemas difíceis, às vezes invencíveis, que a vida a todos oferece. ${ }^{68}$
\end{abstract}

A Módulo n²6, de dezembro de 1961, é um número especial em homenagem ao calculista de Niemeyer, Joaquim Cardozo, que se desligava da equipe, com artigos de Rodrigo Mello Franco, Jorge Amado, Samuel Rawet, Mário Barata, em que fotografias de Marcel Gautherot, sem identificação de autoria, se combinam e são superpostas por desenhos estruturais dos projetos, no layout de Goebel Weyne, da capa às páginas internas. Predominam imagens dos edifícios em obras, além dos operários captados em meio às ferragens das armações, o Palácio da Alvorada recoberto pelos andaimes, a capela, a Catedral e recortes em close das cúpulas do Congresso. Essa forma é escolhida para ilustrar o poema "Prelúdio e elegia de uma despedida", de Joaquim Cardozo - a imagem explora mais uma vez o estetismo construtivo e a fotogenia geométrica imponente da cúpula invertida, desta feita sob forte contraste de luz e sombra (Figuras 36 e 37). Fecham esse número da revista outras obras além das de Brasília, em que o concurso do calculista permitiu a audácia das formas - pilotis robustos do conjunto JK e detalhe da igreja da Pampulha, em Belo Horizonte, o Museu de Brasília, o monumento aos mortos da Segunda Guerra, e a casa das Canoas, no Rio de Janeiro -, obras que fazem parte das séries do acervo de Marcel Gautherot, cuja identificação detalhada resta a fazer.

A omissão de autoria, embora intermitente, parece-nos incompreensível no final dos anos 1950, quando outras revistas iá davam créditos aos fotógrafos desde o início da década (embora, vimos, haja lacunas), como a Architectural Review e a Domus, para lembrar algumas que atribuem a Gautherot fotos como as da Unidade de Habitação em Pedregulho, além da francesa L'Architecture d'Aujourd'hui, em números especiais sobre o Brasil - desde os de 1947 e 1952, até os de 1958 e 1960, sobre Brasília; nesta última, a apresentação informa: "Le reportage photographique sur Brasília a été assuré exclusivement par Marcel Gautherot". No caso de revistas brasileiras, como a Acrópole, em São Paulo, cujos números 256-257 apresentam mais de 100 páginas sobre Brasília, dão-se os créditos aos fotógrafos, embora não individualmente a cada clichê, mas no final do volume - Marcel Gautherot e a Módulo estão listados junto a fotógrafos que eram da redação como José Moscardi, A. Braga, P. Colombo, P. Stricker, Rubens R. dos Santos e Thomas Farkas ${ }^{69}$. 


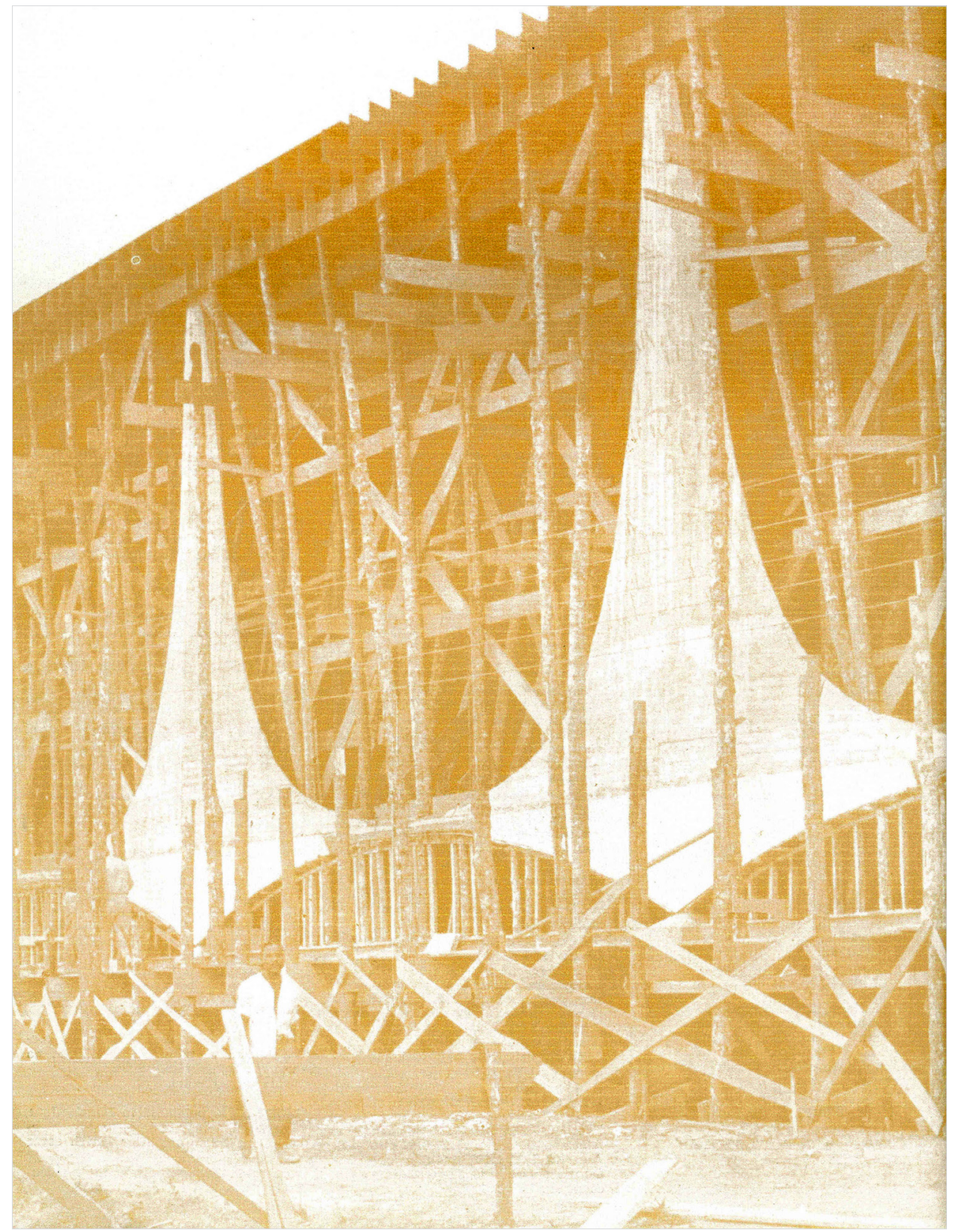

70. Uma pesquisa sobre as pranchas-contato de Marcel Gautherot retratando as obras de arquitetura de Oscar Niemeyer está em curso pela autora deste texto.

Figura 36 - Palácio da Alvorada em construção, fotografia sem indicação de autoria, Módulo n 26 , dezembro de 1961.

As campanhas fotográficas sobre a construção da nova capital brasileira são, pois, decisivas na carreira e difusão internacional da obra de Marcel Gautherot como fotógrafo da arquitetura moderna em revistas do gênero; algumas séries se destacam em relação àquelas de seus contemporâneos, pois vão além da realidade construída, do registro documental da campanha encomendada, afigurando-se muitas vezes como produção autônoma e singular ${ }^{70}$. 
71. Cf. o capítulo "Da exposição, cenografia e obras - a fotografia integrada ao design", em Heliana Angotti-Salgueiro (2007b, p. 14-21). Da mesma forma que estudando montagens do período entre-guerras, reproduzimos na exposição um "diagrama do campo da visão multifacetada" com painéis de fotografias de Gautherot, nos moldes da montagem de Herbert Bayer, da Deutscher Werkbund, na Exposition des Artistes Décorateurs, em Paris, em 1930, certamente visitada por ele. Consultei sobre o tema os textos de Herbert Bayer (1961), Olivier Lugon (1998) e Mary Anne Staniszewski (1998).

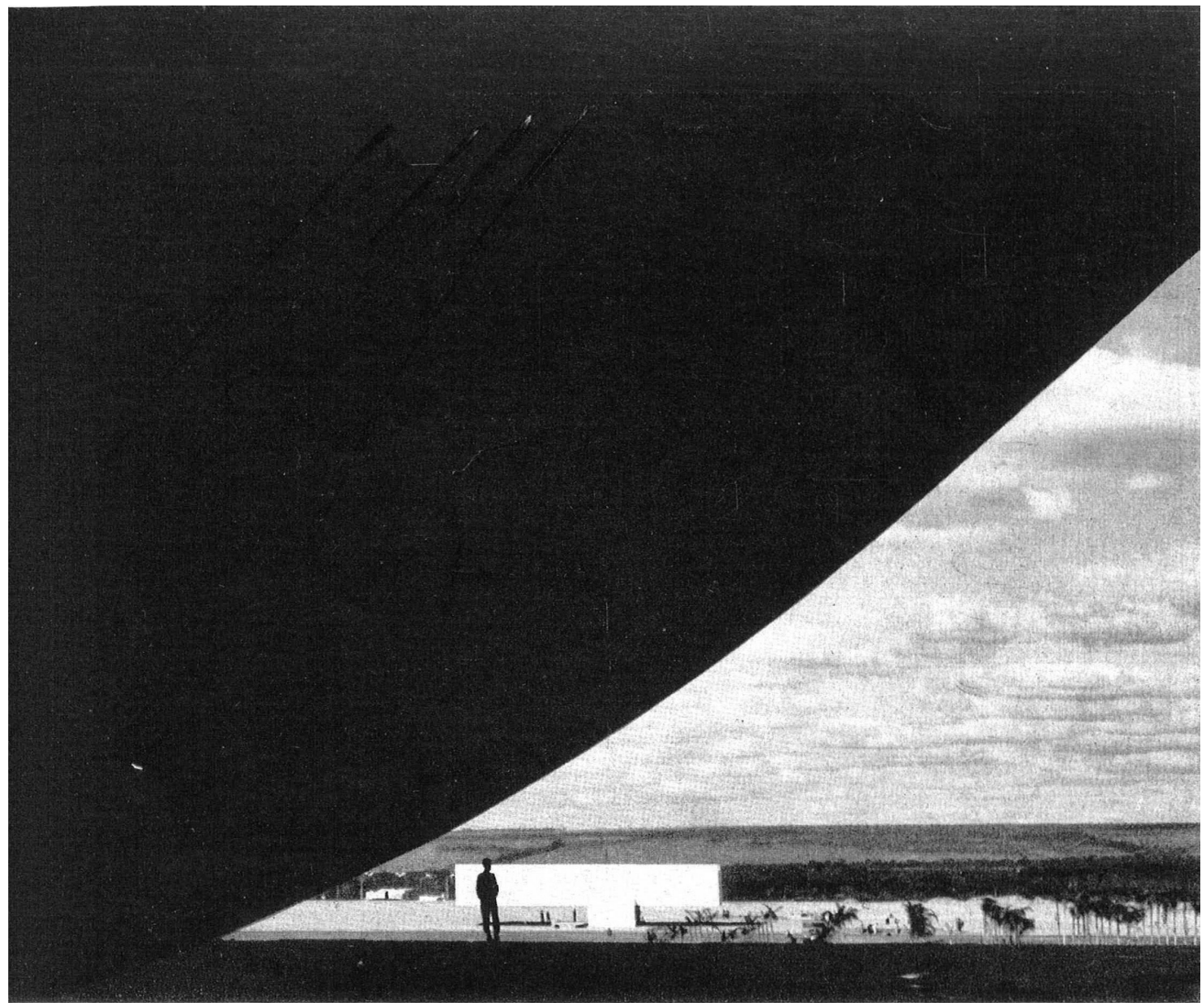

Figura 37 - Vista sob a cúpula do Congresso Nacional, Brasília, fotografia de Marcel Gautherot (sem indicação de autoria), Módulo n² 26, dezembro de 1961.

Fotografias em exposição

Finalmente, além da revista Módulo representar um espaço privilegiado para celebrar o processo de auto-legitimação da arquitetura brasileira, sobretudo ao divulgar a construção de Brasília, ela inclui matérias sobre as demais estratégias de visibilidade desta nova arquitetura: congressos, publicação de livros, e as exposições. Sabe-se que entre as novas formas de comunicação visual da fotografia de arquitetura, as exposições datam dos anos 1920, no cenário da vanguarda internacional. Quando estudei a cenografia da exposição sobre Marcel Gautherot na FAAP, não foi por acaso a opção por uma montagem com citações da museografia "construtivista" de exposições dos anos 1930-1950, pensando em como a fotografia era então exposta ${ }^{71}$ - ou seja, tomando por base painéis fotográficos montados em tubos de metal - tal qual a exposição promovida pela Divisão Cultural do ltamaraty, na UNESCO, em Paris, em novembro de 1958, noticiada com fotos na Módulo n 12, de fevereiro de 1959. Nela são facilmente reconhecíveis painéis com fotografias de Gautherot não só sobre Brasília, tema principal da mostra, mas também 
retratos de suas "mulheres do povo", que ilustram largo painel sobre a demografia do país, embora o nome do fotógrafo não seja citado na reportagem (Figura 38).
72. Cf. J. O. de Meira Penna (1959, p. 38ss). A reportagem desse diplomata, que chefiava a Divisão Cultural

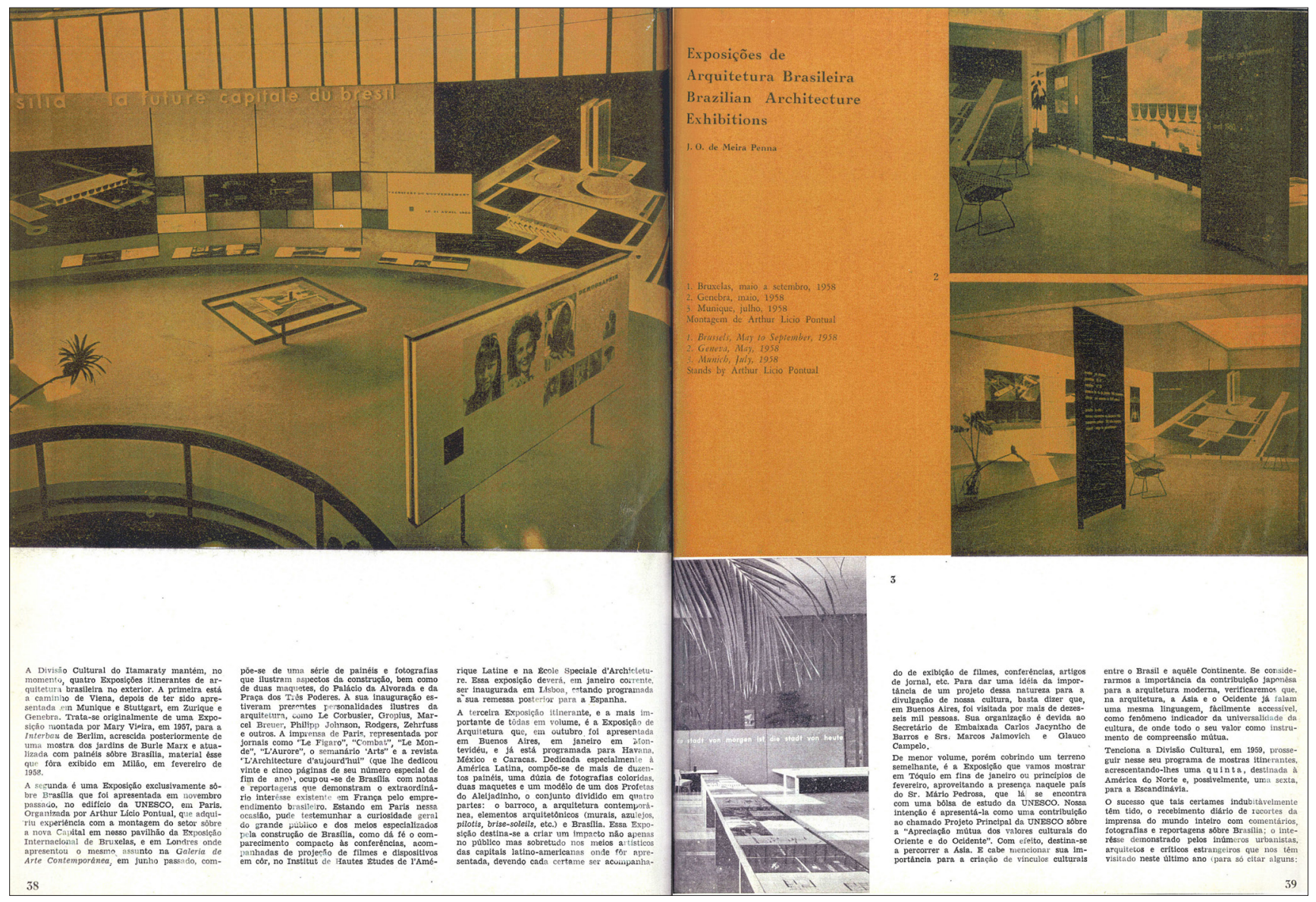

Figura 38 - Páginas da reportagem "Exposições de Arquitetura Brasileira", Módulo n 12, novembro de 1958.

Estas exposições seguem a tendência das revistas quanto aos créditos, em geral ocasionais; aqui se faz a atribuição ao autor da montagem em detrimento do fotógrafo - assim, consta apenas o nome do designer Artur Lício Pontual. Para dar a dimensão do evento, a revista noticia "personalidades ilustres da arquitetura" presentes na inauguração, como Le Corbusier, Gropius, Marcel Brever, Philip Johnson, Rodgers, Zeherfuss e outros, além dos mais destacados porta-vozes da imprensa de Paris: "os jornais Le Figaro, Combat, Le Monde, L'Aurore, o semanário Arts, e a revista L'Architecture d'Aujourd'hui"72 (Figura 39).

A produção fotográfica voltada para modalidades de uso nestes dois registros - a serviço da comunicação visual pelo impresso, no caso as revistas, ou destinada a painéis de exposição, em que se privilegiava o grande formato, típico daqueles anos - certamente direcionou a concepção de muitas das

Annals of Museu Paulista. v. 22. n.1. Jan.-Jun. 2014. do Ministério das Relações Exteriores, levanta um histórico das várias exposições itinerantes que promoveram a arte e especialmente a arquitetura brasileira no exterior naqueles anos, destacando os painéis sobre Brasília, cidade que vinha "causando verdadeira sensação na opinião publica da Europa, dos Estados Unidos e de nossos vizinhos sul-americanos". Sobre as "histórias cruzadas" que uniram Le Corbusier, Niemeyer e Gautherot, ver Heliana Angotti-Salgueiro (2013a). 
fotografias de Brasília feitas por Gautherot. A eficácia visual requerida para a comunicação expositiva passa a fazer parte do processo de criação e produção fotográfica, seja das imagens sobre a arquitetura moderna, muito requisitadas,

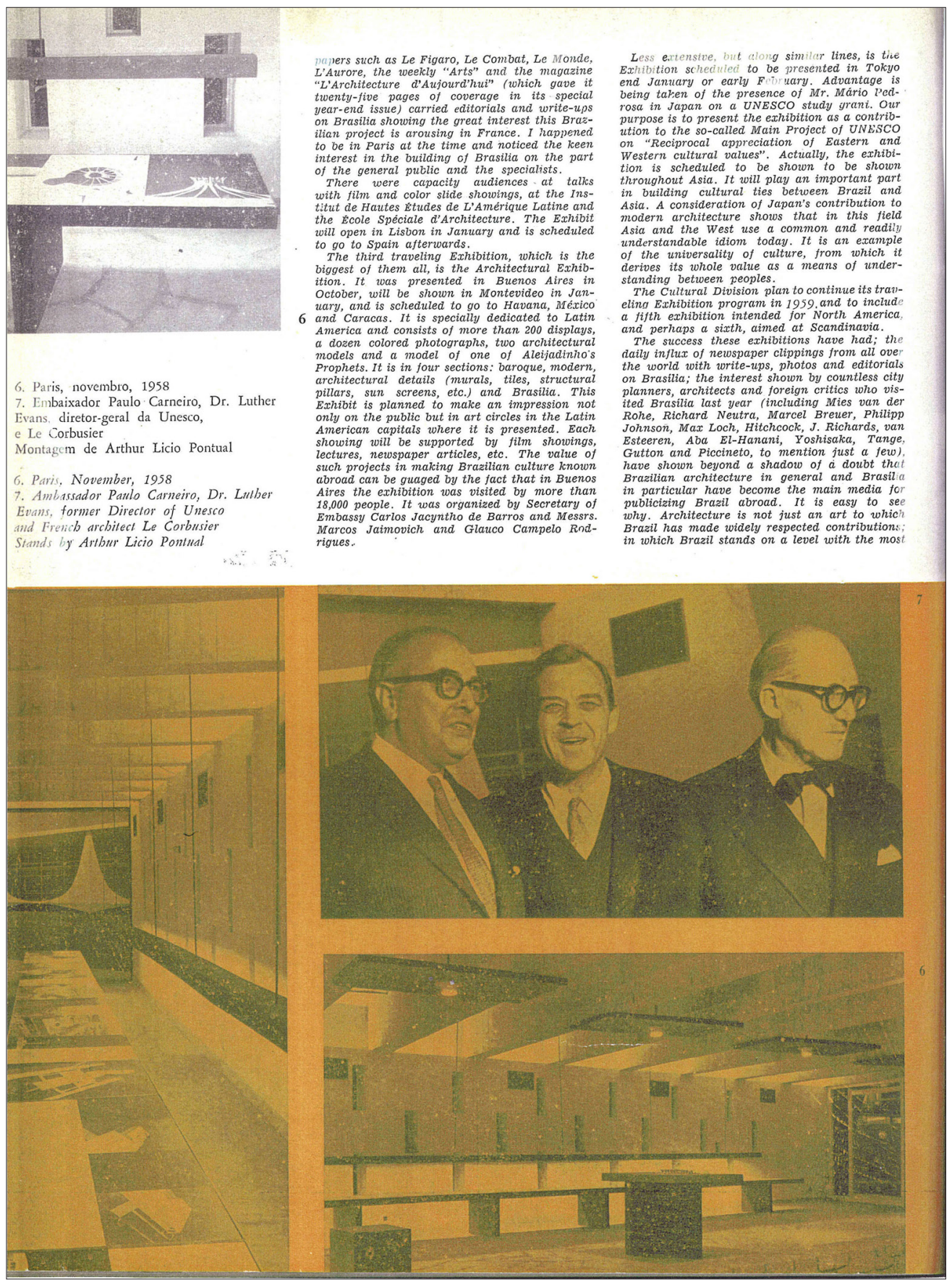

Figura 39 - Le Corbusier na exposição de arte brasileira na Unesco, em Paris, Módulo n 12, novembro de 1958. 
seja das fotos referentes às manifestações culturais populares do país, aos seus "tipos e aspectos", que compõem parte significativa do acervo de Gautherot, e que respondiam, tanto na revista quanto nas exposições, à cristalização e recepção das representações do Brasil veiculadas pelo Estado-Nação, ao mesmo tempo em que despertavam interesse no exterior.

Na Exposição Universal de Bruxelas, em 1958, o Pavilhão do Brasil noticiado na Módulo n 2, é "considerado o melhor de toda a exposição"; obra do arquiteto Sergio Bernardes, que "procura tirar partido do local e das diferenças de níveis existentes, donde a rampa que se desenvolve em torno de um jardim tropical criado por Burle-Marx"73. Essa rampa era ladeada por fotos de Marcel Gautherot em grande formato, com as mesmas temáticas representadas na revista, ou seja, a cultura material, imaterial e a arquitetura moderna. Ele próprio se orgulhava dessa ocasião em que suas fotos foram expostas, destacando aquelas sobre "o folclore e arte popular" na entrevista concedida a Lygia Segala em 1989, já citada.

○ "Noticiário" da Módulo no 18 traz pequena reportagem sobre exposição de arquitetura brasileira em Caracas e Bogotá, também organizada pelo Ministério das Relações Exteriores do Brasil, que abrange desde exemplares da colonização portuguesa até as obras de Brasília, com "farta documentação fotográfica (...) várias maquetes das obras de Oscar Niemeyer e uma réplica do profeta Joel do Aleijadinho na mesma pedra sabão do original". As fotos da reportagem, embora sejam pequenas, permitem o reconhecimento e a identificação de fotografias de Gautherot.

A Módulo n 21 , na página 54, noticia a exposição de arquitetura brasileira nos Estados Unidos (Los Angeles) organizada pelo arquiteto Ricardo Menescal, que "saiu pronta do Rio de Janeiro, com fotografias (aplicadas) em placas de alumínio de fácil embalagem e transporte". Em geral, essas exposições eram forçosamente simples e práticas, pois feitas para montagens e desmontagens em diversos países. Assim é que a Módulo n 32, de março de 1963, noticia a exposição "Arquitetura brasileira na Europa" - projetada por Magalhães, Noronha e Pontual, com "serviços fotográficos de Marcel Gautherot e Michel Aertsens" - cujos temas se distribuíam em três módulos: o barroco, a arquitetura contemporânea e Brasília. Essa exposição foi apresentada em países do Leste europeu e na União Soviética, também pelo Departamento Cultural e de Informação do Ministério das Relações Exteriores; nota-se que em se tratando de uma "exposição itinerante é extremamente leve, sem prejuízo da resistência e durabilidade", compondo-se de 21 painéis sustentados por alumínio anodizado com 90 fotografias coladas nas duas faces dos painéis, e prestando-se a "um máximo de posições e apresentações numa área mínima de $10 \times 6 m^{\prime \prime}$. Um trabalho aprofundado sobre os contextos ideológicos que sustentam estas exposições, e a identificação completa das fotografias de Gautherot ou de outros fotógrafos nelas apresentadas está também para ser feito.
73. Cf. Módulo n. 2, fev.1958, p. 23 
74. Expressões de Olivier Lugon (2004, p 12).

75. Expressão de Yannis Tsiomis (1997, p.77).

76. Cf. Yannis Tsiomis (1997, p. 77)
Considerações finais

Conhecendo o acervo de Marcel Gautherot, podemos afirmar que as fotografias sobre Brasília selecionadas para a revista Módulo são anteriores a outras séries importantes que o fotógrafo fez depois do seu desligamento da equipe a partir do número 28 , em junho de 1962, quando os fotógrafos não são mais identificados no expediente da revista, que traz genericamente a menção das fotos a "Blocks/Clicherias reunidas Latt-Mayer, S.A."

As pranchas-contato do acervo de Marcel Gautherot, conservadas no Instituto Moreira Salles, sobre a nova capital foram classificadas como "Obras gerais", e também especificadas por edifício; elas evidenciam que ele voltou várias vezes ao mesmo local, como era seu costume, para completar as seqüências das séries, fazendo tomadas com aproximações, ângulos e iluminação diferentes. Apropriou-se das formas, captou inclusive sua própria sombra ao lado (ou diante) delas, como para fazer parte da cena ou reverenciá-la - fotos que não foram publicadas na época - assinando assim a autoria, ou "trazendo sua marca sobre o trabalho de outro". Mas a relação entre ele e o arquiteto será sempre um enigma: "o exercício da fotografia de arquitetura parece proceder de uma negociação essencialmente oral, que deixa poucos traços"74 - a banalidade das declarações de Niemeyer, que não vão além da laudatória amical a Gautherot, o comprovam.

Ele sai da Módulo em momento de dificuldades crescentes da revista, para entrar definitivamente no mercado internacional com as imagens da nova capital do Brasil, certo que suas fotografias seriam ainda muito requisitadas para livros e periódicos que já mostravam seu trabalho e o aproveitavam em layouts mais cuidados e devidamente atribuídos, como é o caso da L'Architecture d'Aujourd'hui (Figura 40).

Sabemos que uma revista depende do meio e da conjuntura que a sustentam; nos anos que se seguem pode-se atribuir as modificações e mesmo o empobrecimento do projeto editorial da Módulo que culmina com seu fechamento pelos militares em 1964, à conjuntura histórica que se complica com a saída do presidente Juscelino Kubitschek (que sempre apoiou Oscar Niemeyer) da cena política, nas eleições de 1960.

Brasília marcou a história do urbanismo e da arquitetura não apenas, e afinal, como uma utopia realizada, mas enquanto uma cidade-capital que passou por uma "evolução pragmática"75, com todas as vicissitudes e graves problemas de crescimento excludente, comuns às cidades brasileiras, sem perder, porém, a imagem de sua criação. As opções estéticas de certos contatos de Marcel Gautherot mostram que Brasília "permaneceu, pelo menos nas fotografias, exatamente com a mesma magnitude que as revistas de arquitetura the conferiram"76.

Assim é que, apesar da "propaganda idealizada ter frustrado a expectativa" dos primeiros visitantes que se viram diante de uma cidade artificial sem urbanidade, apesar dos anos de chumbo que alteraram o curso da alvorada de uma "nova era", trazendo, em conseqüência, o esvaziamento da representação 


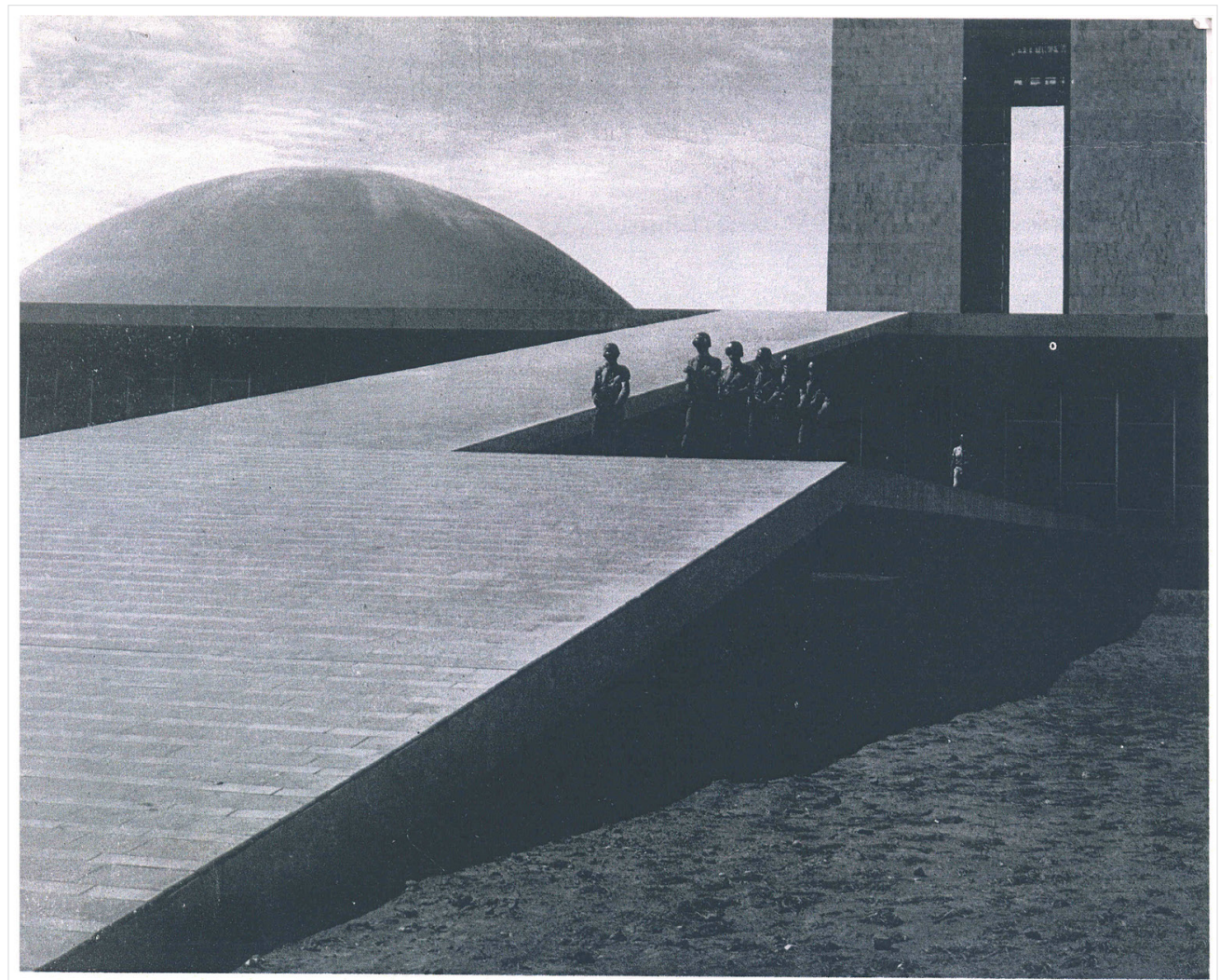

BRASILIA

INTERVIEW DE JUSCELINO KUBITSCHEK, PrésIDEN deS ETATS-UNIS dU gấS

Votre Excellence avait prévu dans son programme d'action du Gouvernement la construction de la nouvelle capitale du Bresil avant même d'avoir assumé le mandat présidentiel. Pouvez-vous nous dire, Monsieur le Président, pou quelles raisons vous avez juge que le transfert de la capitale était devenu imperatif el pourquai la realisation de ce tran fert s'imposait précisement a cet instant de la vie de la nation brésilienne?

Le programme de développement économique du pays. élabore par mon Couvernement et exprimé par mes directives, exigeait une solide intrastructure afin d'atteindre l'équilibre sans lequel on ne pouvait quaggraver encore l'effor desordonné el insoutenable, caracteristique de notre évolution jusqu'a present. II se serait avere impossible de gouverner efficacement un pays divise en deux parties mal equilibrees, lune possedant des richesses surestimees, l'autr payant cher le prix de ce mirage. II ny avait pas un instant à perdre pour assurex la consolidation physique et écono mique du pays, car chaque minute ecoulee élargissai encore la brèche déjà ouverte, et cette tois sans remède.

Le transfert de la capitale à l'intérieur du Brésil, région sous-développée économiquement, s'avérait être le tacteur décisit à la recherche de cet équilibre fondamental, grât au déplacement imposé des ressources issues des centre dinflation vers les regions désheritees et grấce aux choc de toute nature que le transtert du Gouvernement à Brasili provoquerait inévitablement sur les millions d'habitants qi vivent à l'écart des réalités nationales.

En raison de tout ce que Brasilia signifie dans la lutt que nous menons contre le sous-développement de certaine régions de notre pays, la création de notre capitale pel être considérée comme but et comme synthèse.

Quelles seront les conséquences de l'existence de nouvelle capitale au point de vue économique, social politique?

En un mot Brasilia signifie l'ordre nouveau et l'équ libre économique din pays qui depuis quatre cents ne se developpe que le long du littoral, aujourd hui pleine inflation. Iusqua present, du point de vue écol mique, notre pays etait compose en quelque sorte $d^{\prime \prime l} l a$ dispersés. Il tallait imposer une discipline à ce progre désordonné, transformer le pays en un véritable contin
77. Ler a seleção cronológica de críticas sobre Brasília levantada e comentada por Hugo Segawa (2010/2012, p. 35-39)

78. Hugo Segawa (2010 /2012) considera os dados do levantamento de Frederico de Holanda (2002) sobre a recepção positiva $\mathrm{d}$ cidade pelos seus habitantes, independente da classe social a que pertencem, e cita também o resultado do levantamento feito pela Fundação Getúlio Vargas sobre o "alto grau de satisfação de seus moradores".

igura 40 - Página de L'Architecture d'Aujourd' hui, n 90, número especial sobre Brasília, junho-julho de 1960, contendo fotografias de Marcel Gautherot com indicação de autoria.

simbólica de sua "magnitude cultural" fundadora, e apesar da historiografia negativista a respeito de suas contradições ${ }^{77}$, segundo pesquisas recentes ${ }^{78}$, Brasília teria respondido às aspirações humanistas dos CIAM e de Oscar Niemeyer expressas no editorial de abertura da revista Módulo, em 1955 por "uma cidade mais humana e mais feliz"... 


\title{
REFERÊNCIAS
}

PERIÓDICOS (da biblioteca pessoal do autor e consultados na Biblioteca da FAU-USP, São Paulo)

Acrópole, n. 211, 1956.

Acrópole, n. 256-257 (Brasília), 1960.

Architectural Record, v. 111, n. 1, jan. 1952

Architectural Record, v. 112, n. 4, oct. 1952.

Aujourd'hui. Art et Architecture, n. 46, jul. 1964.

Domus n. 254, jan. 1951.

History of Photography, v. 22, n. 2 (Photography and Architecture), Summer 1998.

Lotus International, n. 129, (Photographs) dez. 2006.

L'Architecture d'Aujourd'hui, n. 6, jun.1938.

L'Architecture d' Aujourd'hui, n. 13-14 (Brésil), set . 1947.

L'Architecture d'Aujourd'hui, v. 21, n. 33, dez. 1950, jan. 1951.

L'Architecture d'Aujourd'hui, v. 23, ns. 42-43, ago. 1952.

L'Architecture d' Aujourd'hui, n. 52, jan.-fev. 1954.

L'Architecture d' Aujourd'hui, n. 80, out. 1958.

L'Architecture d'Aujourd'bui, n. 90, jun-jul. 1960.

L'Architecture d'Aujourd'hui, n. 101, abr.-mai. 1962.

Módulo, ns. 1-32, 1955-1963.

The Architectural Review, v. 108, n. 644, ago. 1950.

The Architectural Review, v. 108, n. 646, out. 1950.

The Architectural Review, v. 16, n. 694 (Report on Brazil), out. 1954.

\author{
LIVROS, CATÁLOGOS, ARTIGOS E TESES
}

A REVISTA e o título. Módulo, Rio de Janeiro, n. 1, p. 2, mar. 1955. 
ANGOTTI-SALGUEIRO, Heliana. L'image dans l'œuvre de Pierre Monbeig. Intergéo Bulletin Prodig, Paris, n.especial (L'image ao cour de la géographie), p.77-84, 2001.

. A construção de representações nacionais: os desenhos de Percy Lau na Revista Brasileira de Geografia e outras "visões iconográficas" do Brasil moderno. Anais do Museu Paulista: História e Cultura Material, São Paulo, v. 13, n. 2, p. 21-72, jul.-dez. $2005 a$.

. Introdução (ao Dossiê "Representações do Brasil: da viagem"). Anais do Museu Paulista: História e Cultura Material, São Paulo, v. 13, n.2, p. 11-20, 2005b.

Do Arquivo ao Banco de Dados. Documentos textuais e iconográficos. In: ANGOTTI-SAlgueIRO, Heliana (org.). Pierre Monbeig e a geografia humana brasileira. A dinâmica da transformação. Bauru: Edusc, 2006.

Representer et vivre le modernisme brésilien: la maison d'Oscar Niemeyer à Rio de Janeiro dans l'optique de Marcel Gautherot. In: GRIBENSKI, Jean; MEYER, Véronique; VERNOIS, Solange (org.). La Maison de l'Artiste. Constructions d'um espace de représentations entre réalité et imaginaire (XVIIe-XXe siècles). Rennes: Presses Universitaires de Rennes, 2007a. (Collection Art et Société).

Marcel Gautherot et la naissance photographique de Brasília. In: VIDAL, Laurent (dir.). La ville au Brésil (XVIIIe-XXe siècles). Naissances, renaissances. Paris: Les Indes Savantes, 2008.

Architecture and Photography: Connected Histories. EAHN CONFERENCE (Architectural Elective Affinities - transfers, correspondance, inter/multiplicinarity), São Paulo, FAU-USP, 2013a (inédito).

Pierre Verger e Marcel Gautherot, da França ao Brasil: experiências cruzadas e convenções de representação. In: PERRONE-MOISÉS, Leyla. Cinco séculos de cultura francesa no Brasil. São Paulo: Edusp, 2013b.

Brasília, ville radieuse photogénique. In: OECHSLIN, Kornelia Imesch (dir.). La Chaux-de-Fonds, Chandigarh, Brasília. Utopie et réalité de l'urbanisme au XXe siècle. La Chaux-de-Fonds: Gollion, Infolio éd., no prelo.

Portraits et autres représentations dans l'œuvre photographique de Pierre Verger: le voyage au Mexique. Nuevo Mundo Mundos Nuevos, Paris, n. 14, 2014. Disponível em <http://nuevomundo.revues.org/66225>, acesso em 04/06/2014.

ANGOTTI-SAlgUEIRO, Heliana (org.) O olbo fotográfico. Marcel Gautherot e seu tempo. São Paulo: FAAP, 2007b.

ANDRIEUX, Beatrice; BAJAC, Quentin; RICHARD, Michel; SBRIGLIO, Jacques. Le Corbusier /Lucien Hervé. Contacts. Paris: Seuil, 2011.

BAUDIN, Antoine (dir.). Photographie et architecture moderne. la collection alberto sartoris. Lausanne: Les Archives de la Construction Moderne; Presses polytechniques et universitaires romandes, 2003. 
BAYER, Herbert. Aspects of Design of Exhibitions and Museums. Curator, Nova York, v. $4, \mathrm{n}$. 3, p. 257-288, 1961.

BLOC, André. Ayons confiance dans l'architecture contemporaine, L'Architecture d'Aujourd'hui, Paris, v.23, ns. 42-43, ago. 1952.

BONAZZI, Rafael Miura. Athos Bulcão and the Architecture of Brasília. Docomomo Journal, Eindhoven, n. 43 (Brasília 1960-2010), p. 52-55, 2010/2.

BOONE, Véronique. Une image d'architecture, Lucien Hervé dans le cadre de l'evolution de la photographie d'architecture. In: BERGDOLL, Barry et al. Lucien Hervé. L'œil de l'architecte. Bruxelas: CIVA, 2005.

CAPPELLO, Maria Beatriz Camargo. Arquitetura em Revista. Recepção da arquitetura moderna brasileira nos periódicos italianos, ingleses e franceses (1945-1960). Tese (Doutorado) Universidade de São Paulo / Faculdade de Arquitetura e Urbanismo, São Paulo, 2005.

CHÉROUX, Clément. Henri Cartier-Bresson. Paris: Éditions du Centre Georges Pompidou, 2013.

COLLINS, Peter. Modulor. The Architectural Review, v. 116, n. 691, jul. 1954.

GIEDION, Sigfried. Le Brésil et l'architecture contemporaine. L'Architecture d'Aujourd'hui, Paris, v. 23, ns. 42-43, ago. 1952.

Building in France, Building in Iron, Building in Ferro-Concrete. Santa Monica: The Getty Center Publication Programs, 1995 [1928].

GOODWIN, P. L. Brazil Builds. Architecture Old and New 1652-1942. Nova York: The Museum of Modern Art, 1943.

GOUVEIA, Sonia M. Milani. O homem, o edifício e a cidade por Peter Scheier. Dissertação (Mestrado) - Universidade de São Paulo / Faculdade de Arquitetura e Urbanismo, 2008a.

A fotografia de arquitetura de Peter Scheier em três publicações. Panorama da fotografia em Brazil Builds, Latin American Architecture e Modern Architecture in Brazil. Pós - Revista do Programa de Pós-Graduação em Arquitetura e Urbanismo da FAU/USP, São Paulo, v. 15, n . 24, p. 80-99, dez. 2008b.

HAUS, Andreas. Fotogene Architektur. Daidalos, Berlin, n.66, p. 84-91, dez. 1997.

HERSCHDORFER, Nathalie \& UMSTÄTTER, Lada (dir.). Construire l'image: Le Corbusier et la photographie (catálogo da exposição no Musée des Beaux-Arts de La Chaux-de-Fonds). Paris: Ed. Textuel, 2012.

HITCHCOCK, Henry-Russel. Latin American Architecture since 1945. Nova York: The Museum of Modern Art, 1955.

HOLANDA, Frederico de. O espaço de exceção. Brasília: Editora da UnB, 2002.

JANNIÈRE, Hélène. Politiques éditoriales et architecture "moderne". L'émergence de nouvelles revues en France et en Italie (1923-1939). Paris: Éditions Arguments, 2002. 
JANNIÈRE, Hélène.De l'art urbain à l'environnement: le paysage urbain dans les écrits d'urbanisme em France, 1911-1980. Strates. Matériaux pour la recherche en Sciences Sociales, Paris, n.13, p. 51-66, 2007.

Le Corbusier, une encyclopedie (catálogo da exposição L'aventure Le Corbusier). Paris: Centre Georges Pompidou, 1987.

LE CORBUSIER. La construction des villes. Paris: L'Âge d'Homme, 1992 [1910].

LENIAUD, Jean-Michel; BOUVIER, Béatrice (org.). Les périodiques d'architecture. XVIIe-XXe siècle. Recherche d'une méthode critique d' analyse. Paris: École de Chartes, 2001.

LUGON, Olivier. La Photographie en Allemagne. Anthologie de textes (1919-1939). Nîmes: Éditions Jacqueline Chambon, 1997.

. La photographie mise en espace. Les expositions didactiques allemandes (1920-1930). Études Photographiques, Paris, n. 5, nov. 1998.

. Le Marcheur. Piétons et photographes au sein des avant-gardes. Études photographiques, Paris, n.8, p. 68-91, nov. 2000.

. Le style documentaire. D'August Sander à Walker Evans 1920-1945. Paris: Macula, 2001.

. Maisons signées, images anonymes. In: BAUDIN, Antoine (dir.). Photographie et architecture moderne. La collection Alberto Sartoris. Lausanne: Les Archives de la Construction Moderne/Presses polytechniques et universitaires romandes, 2003.

. La question de l'auteur. Tracés. Bulletin Technique de la Suisse Romande, Lausanne, n. 01/02 (Architecture et Photographie), p.10-13, jan. 2004.

Esthétique du document: le réel sous toutes ses formes (1890-2000). In: GUNTHERT, André; POIVERT, Michel ed.). L'Art de la photographie. Paris: Citadelles \& Mazenod, 2007a.

$2007 b$.

. La photographie des typographes. Études Photographiques, Paris, n. 20, p.100-119, jun.

Séries, sequências e pranchas-contato. In: ANGOTTI-SALGUEIRO, Heliana (org.) $O$ olbo fotográfico. Marcel Gautherot e seu tempo. São Paulo: FAAP, 2007c.

MENDIBIL, Didier. Le formatage iconotextuel de l'imagerie geographique des villes. In: POUSIN, Fréderic (dir.). Figures de la ville et construction des savoirs. Architecture, urbanisme, géographie. Paris: CNRS éd., 2005.

. O sistema iconográfico da geografia clássica francesa e Pierre Monbeig. In: ANGOTTISALGUEIRO, Heliana (org.). Pierre Monbeig e a geografia bumana brasileira. A dinâmica da transformação. Bauru: Edusc, 2006.

MINDLIN, Henrique. Arquitetura Moderna no Brasil. (Lauro Cavalcanti, org.) Rio de Janeiro: Aeroplano; IPHAN, 2000.

NIEMEYER, Oscar. (Nota sem titulo), Módulo, Rio de Janeiro, n. 1, p. 3, mar. 1955a. 
. Problemas atuais da arquitetura brasileira. Módulo, Rio de Janeiro, n. 3, p.18-22, dez.

$1955 b$.

A imaginação na arquitetura. Módulo, Rio de Janeiro, n. 15, p.6-13, out. 1959.

Minha experiência de Brasília. Módulo, Rio de Janeiro, n. 18, p. 11-27, jun. 1960a.

Forma e função na Arquitetura. Módulo, Rio de Janeiro, n. 21, p. 2-7, dez. 1960b.

PAPADAKI, Stamo. Oscar Niemeyer. Nova York: George Braziller, 1960.

PENNA, J. O. de Meira. Exposições de arquitetura brasileira. Módulo, Rio de Janeiro, n. 12, p. 38-43, 1959.

PESSOA, José. Lucio Costa and the question of Monumentality in his Pilot Plan for Brasilia. Docomomo Journal, Eindhoven, n.43, p. 22-25, 2010/2012.

SARTORIS, Alberto. Encyclopédie de l'Architecture Nouvelle (v. "Ordre et Climat Américains") Milão: Ulrico Hoepli, 1954.

SEGALA, Lygia. Fotografia, folclore e cultura popular. Cadernos de Antropologia e Imagem, Rio de Janeiro, n. 8, p. 81-98, 1999.

Bumba-meu-boi Brasil. In: O BRASIL de Marcel Gautherot. São Paulo: Instituto Moreira Salles, 2001.

Folclore e cultura popular. In: ANGOTTI-SALGUEIRO, Heliana (org.) O olbo fotográfico. Marcel Gautherot e seu tempo. São Paulo: FAAP, 2007a.

Patrimônio histórico, artístico e cultura material. In: ANGOTTI-SALGUEIRO, Heliana (org.) O olbo fotográfico. Marcel Gautherot e seu tempo. São Paulo: FAAP, 2007 b.

A viagem ao México - primeira reportagem fotográfica, In: ANGOTTI-SALGUEIRO, Heliana (org.) O olho fotográfico. Marcel Gautherot e seu tempo. São Paulo: FAAP, 2007c.

O clique francês no Brasil: a fotografia de Marcel Gautherot. Acervo. Revista do Arquivo Nacional, Rio de Janeiro, v. 23, n. 1, p. 119-132, jan-jun 2010.

Ginga, golpe e instante: a capoeira de Angola baiana nos estudos de Edison Carneiro e nas fotografias de Marcel Gautherot. Cultures-Kairós - Revue d'anthropologie des pratiques corporelles et des arts vivants, Paris, n. 30, p. 1-20, 2012.

SEGAWA, Hugo. A Myth that Left the Greenhouse. Docomomo Journal, Eindhoven, n. 43, p. 34-39 2010/2012.

STANISZEWSKI, Mary Anne. The Power of Display. A History of Exhibition Installations at the Museum of Modern Art. Cambridge: The MIT Press, 1998.

TRAVAUX du Ier Congres International de Folklore. Tours: Arrault et Cie, 1937. 
TSIOMIS, Yannis. 1957, naissance d'une capitale. L'Architecture d'Aujourd hui, Paris, n. 313, p. 75-79, out. 1997.

ZEIN, Ruth Verde. Oscar Niemeyer. Da crítica alheia à teoria própria. Arquitextos, São Paulo, ano 13, n. 151.04,Vitruvius,dez.2012. Disponível em <http://www.vitruvius.com.br/revistas/ $\mathrm{read} /$ arquitextos/13.151/4608>, acesso em 01/03/2014.

Artigo apresentado em 06/11/2012. Aprovado em $31 / 05 / 2014$. 